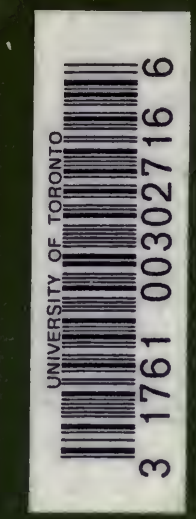


<smiles>C=CC</smiles> 






\section{The New Science and English Literature in the Classical Period}

\section{A DISSERTATION}

SUBMITTED TO THE FACULTY OF THE GRADUATE SCHOOL OF ARTS AND LITERATURE IN CANDIDACY FOR THE DEGREE OF DOCTOR OF PHILOSOPHY

(DEPARTMENT OF ENGLISH)

BY

CARSON S. DUNCAN

MENASHA, WIS.

THE COLLEGIATE PRESS GEORGE BANTA PUBLISHING CO.

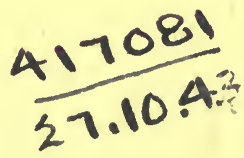




\section{PR \\ 149 \\ 5408}

COPYRIGHT I9I3

BY

C. S. Duncan
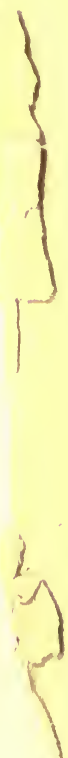


\section{CONTENTS}

PAGE

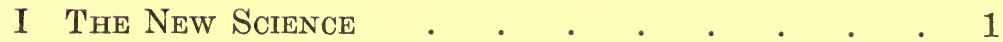

II The Conflict of Old and New Ideas . . . $\quad$. 29

III The New Science and Comedy . • . . . . 66

IV The New Science and Poetry . . . . . . . . 111

V The New Science and Prose . . . . . . . 147

VI Conclusion . . 



\section{CHAPTER I}

\section{The New Science}

The new science, or the new experimental philosophy, arose in England as a fresh intellectual impulse, too subtle and too penetrating to be readily confined within the bonds of a definition. Its manifestations may be observed, its more obvious qualities may be studied, yet back of all these there is an elusive psychological problem that fairly challenges solution. As the waters of a stream are lost in the sea, where they are driven by unknown forces to break on anexpected shores, so new ideas entering the minds of men are lost to analysis only to reappear as new points of view, new methods of thinking, new attitudes toward life. Straightway men possessed of these new ideas set to work reforming human thought. Similarly, experimental philosophers in seventeenth century England, quickened by this new intellectual impulse, began to lay, broad and deep, the foundations for reconstructing the natural history of the world.

Scientific interest had existed in England long before the seventeenth century, ${ }^{1}$ of course, and can be called a new interest in that period only in the sense that it received a new impetus. This new impulse came from the influence of four men, two foreigners and two Englishmen, Galileo and Descartes, Bacon and Harvey. When Galileo made his telescope and saw the proof of the Copernican theory, there was introduced the fundamental new principle,namely, the application of mechanical apparatus to the solution of the problems of natural philosophy. "Since that Galileo," wrote John Wallis, "and (after him) Torricelli, and others have applied Mechanick Principles to the salving of Philosophical Difficulties; Natural Philosophy is well known to have been rendered more intelligible, and to have made a much greater progress in less than a hundred years, than before for many ages". ${ }^{2}$ To Bacon is attributed the inductive method for scientific research, although as Pro-

1 Cf. Adamson's Roger Bacon; the Philosophy of Science in the Middle Ages; Berthelot's Introduction to a Collection of Ancient Treatises on Chemistry and Alchemy; Bridges's Introduction to Roger Bacon's Opus Majus; Bon's Roger Bacon; Charles's Roger Bacon et Sa Vie; La Croix's Science and Literature in the Middle Ages; Phillips's Science in England from Elizabeth to Charles II; Wright's Science Written During the Middle Ages.

${ }^{2}$ Wallis, John, Phil. Trans. vol. I-II, p. 264, Letter to the R. S. 
fessor Adamson truthfully says, "it is more than probable that in all fairness, when we speak of the Baconian reform of science, we should refer to the forgotten Monk of the thirteenth century rather than to the brilliant and famous Chancellor of the seventeenth". 3 The new philosophers themselves were not familiar with the work of "Friar Bacon", while they persistently praised and honored the chancellor, and followed as well as they could his precepts as they found them in the Novum Organum. They became his disciples and "were not slow in carrying out the plan of a learned society as sketched in the New Atlantis"." To him is due, then, the working hypothesis-the inductive method-, wherein a long and careful process of experimentation and observation must precede the drawing of conclusions.

The third element was furnished by Descartes. He was a mathematician as well as a philosopher, and hence could bring mathematical accuracy and precision to the aid of philosophical thinking. His great service, therefore, lay in his reducing to formulae the facts gleaned from experiment and observation. "Monsieur Descartes .... . did not perfectly tread in his (Bacon's) Steps, since he was for doing too great a part of his work in his Closet, concluding too soon, before he had made Experiments enough; but then to a vast Genius he joined exquisite Skill in Geometry, and working upon Intelligible Principles and an Intelligible Manner . . . . . obtained his results." ${ }_{5} \mathrm{He}$ also joined forces with Bacon against the power of ancient authority. "Bacon shares with Descartes the honour of inaugurating the modern period of philosophy. Bacon's protest against the principle of authority, a principle which had been accepted with more or less unhesitating loyalty by the Scholastic philosophers, is no less vigorous than that of Descartes. Both alike are eager to substitute for faith and tradition the independent effort of the individual mind in pursuit of truth."

Harvey's chief influence was due to his achievements. Trained

3 Adamson, R., Roger Bacon, p. 7.

4 Becker, B. H., Scientific London, p. 2.

5 Wotton, William, Reflections upon Ancient and Modern Learning, p. 30.

- "But one conclusion emerges out of these considerations, viz. not, indeed that arithmetic and geometry are the sole sciences to be studied, but only, that in our search for the direct road towards truth we should busy ourselves with no object about which we cannot attain a certitude equal to that of the demonstrations of arithmetic and geometry".-Descartes, Phil. Wks., vol. I, p. 5. 
in the new scientific methods under Fabricius at Padua and filled with an enthusiasm for discovery, he returned to England to apply with clear-sightedness and commonsense the new principles to physiological research. The result was that he startled the-learned world and stimulated intellectual curiosity with his discovery of the circulation of the blood. ${ }^{7}$

These are the elements underlying the new science of the seventeenth century in England in so far as they can be concretely defined. "The period had arrived when that experimental philosophy to wilich Bacon had held the torch, and which had already made considerable progress, especially in Italy, was finally established on the ruins of arbitrary figments and partial inductions".8 But, while the mind can easily grasp these tangible elements,--the use of scientific apparatus in solving philosophical problems, the inductive method of investigation, and the reduction of philosophical ideas to mathematical formulae-there still remains a subtle and powerful force. The new science was more penetrating than the above definition indicates; it was an attitude of mind, it was a declaration of intellectual independence. "Nullius in Verba is not only the motto of the Royal Society, but a received Principle among all the Philosophers of the present Age." Not only are new discoveries to be made; new investigations to be carried on, but the old beliefs are to be re-examined. Aristotle and Descartes are to be of exactly the same authority so far as mere assertion is concerned. ${ }^{10}$ No authority is to be convincing because it is ancient; no conclusion is to be scouted because it is new. ${ }^{11}$

This interest in scientific research crystallized into definitely organized societies. The Society of Antiquaries was formed at London in 1572 and continued into the seventeenth century until dissolved by James I. A Royal Academy was attempted as early as 1616-17, in which it was planned to devote some attention to science. Sir Francis Kynaston renewed the attempt in $1635 .^{12}$

${ }^{7}$ Announced 1616; published 1628.

${ }^{8}$ Hallam, Henry, Introduction to the Lit. of Eur. vol. IV, p. 518. Cf. also, Becker, B. H., Scientific London, p. 1.

- Wotton, William, Reflections, p. 251.

${ }^{10}$ Wotton, William, Reflections, p. 364.

11 Ibid.

12 Elton, Oliver, The Augustan Ages, p. 383. 
But this study is centralized in the work and influence of the Royal Society of London. It did not absolutely lead the way, but it had a wholly independent development. There was in Florence an earlier society, Accademia del Cimento, with "provando e riprovando la natura" for its motto. "This body was more purely scientific in its plan than the Royal Society", but it was clearly an outgrowth of the same movement. ${ }^{13}$ In 1666 the French Academy of Science was founded, showing that scientific interest was awakened in Paris. Bishop Sprat thought, with some show of reason, that the French imitated the English. ${ }^{14}$ The question of source is eliminated from the discussion of the history of the Royal Society, because it had a definite English origin in Bacon's New Atlantis. ${ }^{15}$

As early as 1645 this common interest in England had drawn together a group of men, who had grown weary of the political and religious turmoil of the times. ${ }^{16}$ These men began a series of weekly meetings in the lecture room of the Professor of Astronomy at Gresham College. There was at first no definite organization or plan of procedure, although by 1651 there were rules printed intended for regulating the election of members, (fines for "defaults" 2s. 6d.), and even setting the time of meetings,-- "every Thursday, before two of the clock". ${ }^{17}$ This company was called by Sir Robert Boyle, an early member, the "invisible College". ${ }^{18}$ Their discussions were limited by agreement to the "New Philosophy", i. e. to a study of things around them in nature, what they could see, touch, feel, or hear, "(not meddling with Divinity, Metaphysicks, Moralls, Politicks, Grammar, Rhetoric, or Logic) ". ${ }^{19}$

The company slowly increased. In 1658 there were twelve members, among whom were Wilkins, Seth Ward, Wallis, Sir Robert Moray, and Boyle. During this year several of the members were

13 Sprat, Thomas, History of the Royal Society, p. 56.

14 It became an era for societies. Cf. Minerva's Museum; see also, account of "Academy at the great Tew", The Rota, The Hartlib Group, The Athenian Society, Society for Physicians and Surgeons. Later branch societies sprang up in outlying towns; cf. Spalding, Lincolnshire.

15 Bacon, Francis, The New Atlantis, Solomon's House.

${ }^{16}$ Ranke, Leopold von, History of England, vol. VI, p. 361.

${ }^{17}$ Weld, C. R., History of the Royal Society, pp. 33-4.

18 Ibid. p. 38.

10 Wallis, John, Letter to the Royal Society, 1696. 
called away to Oxford, whither they carried the new interest, and where they began a similar series of meetings. In this manner the scientific enthusiasm continued through the Commonwealth. In 1660 the two sections were united at Gresham College, and were formed into a definite organization. The number of members increased during the year to 115 . The next year the attention of the new King was called to it by Elias Ashmole, and the King took an immediate interest in it. Dr. Johnson has suggested that his interest" was not wholly scientific, but rather political. "It has been suggested", he writes, "that the Royal Society was instituted soon after the Restoration, to direct the attention from public discontent". ${ }^{20}$ From whatever motive, Charles II did grant the Society a Royal Charter and the privilege of using the Royal Arms, and gave it a silver mace which it possesses and uses to this day. ${ }^{21}$ The organization was completed August 29, ${ }^{22}$ 1662, at which time the King declared himself to be the founder of the Society. In this way came into being the Royal Society of London for the Promotion of the Natural Sciences (Societas Regalis Londini pro Scientia Naturali Promovenda), which has continued from that time to this, growing in power and influence. The "Invisible College" had become the "Visible Church of Philosophy". ${ }^{23}$

Out of that tumultuous mid-century, therefore, came this new interest, called the New, or Experimental Philosophy. Its followers were called philosophers, or more usually, virtuosi. What was their aim? In brief, it was to realize if possible the ambition of Bacon, to reconstruct the natural history of the world. ${ }^{24}$ The broad foundation of this stupendous and profound history was to be laid by means of experiments. Everything was to be examined anew, and a careful record was to be kept, so that gradually but surely there should arise out of the chaos of scholastic discussion this new understanding; this solid mass of truth should grow into definition. These scientists were to accept nothing simply from report (nullius in verba); there must be demonstration wherever possible,

20 Johnson, Samuel, Works, vol. X, p. 36.

21 Masson, David, Life of Milton, vol. VI, p. 395 ; Becker, B. H., Scientific London, Chap. I.

22 The Charter was dated April 22, 1662.

23 Weld, O. R., History of Royal Society, p. 73.

24 Boyle, Robert, Phil. Trans. vol. I-II, p. 186. Cf. also, Bacon's plan for Book VI, Instauration of the Sciences. 
otherwise the best evidence that could be obtained. When it is remembered that some of these men actually believed in witchcraft (Glanvil), sympathetic powder (Sir Kenelm Digby), curing by stroking (Boyle), and whatnot of superstition, this broad and liberal intellectual policy is remarkable. The appeal, it will be seen, was directly to commonsense and to reason, which at first led to a general sceptical attitude. "When a discussion arose regarding St. Andrew's Day (Nov. 30) for celebrating the anniversary of their foundation, after St. George and St. Isidore (a canonized philosopher) had been suggested as more fitting patron saints, Sir William Petty said,--No, I would rather have had it on St. Thomas's Day, for he would not believe till he had seen and put his hands into the holes of the nails' ', ${ }^{25}$

In order to reconstruct the natural history of the world, their aim was to study nature as Bacon had advised;- "The end of our foundation is the knowledge of causes" ${ }^{28}$ "The business and design of the Royal Society is-

"To improve the knowledge of Naturall Things, and all useful Arts, Manufactures, Mechanick Practices, Engynes and Inventions by Experiments. . . . .

"To attempt the recovering of such allowable Arts and Inventions as are lost.

"To examine all Systems, Theories, Principles, Hypotheses, Elements, Histories, and Experiments of Things, Naturall and Mechanical, invented, recorded, or practiced, by any considerable author ancient or modern. In order to a compiling of a complete system of solid philosophy for explicating all phenomena produced by Nature or Art, and recording a rational account of the causes of things. In the meantime this Society will not own any Hypothesis, System, or doctrine of the Principles of Naturall Philosophy, proposed or mentioned by Philosopher ancient or modern, nor the explication of any phenomena whose recourse must be had to originall causes (as not being explicable by Heat, Cold, Weight, Figure, and the like, as Effects produced thereby); nor dogmatically define, nor fix axioms of scientific Things, but will question and canvass all till by mature debate and clear arguments, chiefly such

25 Wheatley, H. B., Samuel Pepys and the World he Lived In, p. 123.

${ }^{26}$ Weld, C. R., History of R. S. "Natural opposed to supernatural", p. 126. 
as are deduced from legitimate Experiments, the Truth of such Experiments be demonstrated". ${ }^{27}$ This is certainly a most ambitious program with which to begin, and yet there is something valiant and attractive about it. May one not call this the intellectual Magna Charta of the seventeenth century!

This band of philosophers had thus early set for themselves the task of founding a system of philosophy, not for England, nor for Scotland, nor Ireland, nor the Pope, nor the Protestants, but for mankind. ${ }^{28}$ Men were admitted to membership "of different Religions, Countries, and Professions of Life". When Charles II learned that a Tradesman had contributed a paper to the Society, he sent a note of congratulation to the members and urged them to admit as many such men as possible. "On the 20th November, 1663, the Royal Society consisted of 131 Fellows, of whom 18 were Noblemen, 22 Baronets and Knights, 47 Esquires, 32 Doctors, 2 Bachelors of Divinity, 2 Masters of Arts, and 8 Strangers, or Foreign Members." ${ }_{29}$ This enumeration has certain elements of interest. A clear majority are gentlemen of leisure, who must depend upon an innate or acquired devotion to scientific research in order to save their efforts from mere dilettanteism. Then a goodly number are physicians whose work ought, at least, to be of a serious character. That Bachelors of Divinity belong is noteworthy in the light of subsequent charges of atheism levelled at the members of this scientific organization.

The early historian of the Royal Society, himself a member, has given an interesting description of the ideal philosopher. "First, he should have the industry, activity, and Inquisitive Humour of the Dutch, French, Scatch, and English in laying the groundwork, the heap of Experiments. And then he should have added the cold, and circumspect, and wary disposition of the Italians and Spaniards, in meditating upon them, before he fully brings them into speculation"'. ${ }^{30}$ This is, of course, a composite character combining the chief qualities of all the leading European nations as then known. From our standpoint, with a knowledge of the later accomplishments in science of these peoples, this early

\footnotetext{
${ }^{27}$ Hooke, Robert, MS. Papers, quoted by Weld, History of R. S. p. 146.

${ }^{28}$ Sprat, Thomas, Hist. of R. S. p. 63.

20 Manuscript List of Fellows of Royal Society;-Brit. Museum MSS. 4442.

80 Sprat, Thomas, History of the Royal Society, p. 64.
} 
analysis is interesting. It must be remembered that Englishmen were still going to Italy for advanced scientific study, especially in medicine, after the example set by Harvey.

Bacon had held up a high standard of accuracy in The New Atlantis;-observe, experiment, and at last conclude, had been his dictum. The ideal philosopher was to have industry, activity, and an inquisitive humor, a cold, circumspect and wary disposition in drawing conclusions. This was the theory; what was the practice? An example of method from the work of one of the foremost members of the Society will illustrate it. Some observations had been made and reported to the Royal Society on "phosphorescent glow" arising from rotting wood and decaying vegetable and animal matter. Robert Boyle grew interested. In a letter dated February 15, 1672, he reports a number of experiments carried on by himself. One night when he was retiring, his servant announced to him a remarkable phenomenon in the larder. Among many pieces of meat hanging there was one, a neck of veal, that was luminous. Boyle, like a true philosopher, began an investigation, and, though at the time almost bedfast from a cold contracted during some recent atmospheric experiments, caused the piece of meat to be conveyed to his bedroom. For several hours that night he lay and watched it closely for indications of variations in brilliancy. Then he put it under a receiver and pumped out the air;-_"whereupon", he says, "the light was well-nigh eclipsed". He kept the bit of "lucid flesh" in his bedroom during several days, convenient for observation, and manifold were the experiments performed. For instance, a servant was commanded to run her hand over the phosphorescent surface. The hand was found to shine, but no heat was felt. "By great good fortune", he declares, "I had a copy of the Philosophical Transactions with me. I was able so to apply that flexible paper to some of the more resplendent spots that I could plainly read divers consecutive letters of the title". The writer then summarizes his observations: "(1) Twenty places did shine. (2) The patches were of varying size. (3) It shone best where the Butcher's cleaver passed through. (4) The light was varying in colour. (5) There was no heat. (6) There was no stench, etc. . . . ."

No sooner had the news of these experiments been noised abroad than pieces of "lucid flesh" began to appear to many. One, J. 
Beal, wrote to the society May 22, 1676, ${ }^{31}$ that he had heard of "a piece of fresh Beef shining in the Strand". It became a sensation as remarkable as Moses' burning bush,-a seven days' wonder. These men of the New Science began to look at such commonplace phenomena with the wondering eyes of children. Here is an inquisitive humor, an industry, an activity, but one doubts the existence of a cold, circumspect and wary disposition.

The experiment cited above is typical. It can be duplicated from attempts at transfusing blood, from observing thunderstorms, from watching the circulation of blood in the foot of a frog, from the trials of the effects of rarified air, from almost any page of Hooke's Micrographia. Always the attitude is the same; wonder and interest, experiment and observation, then a careful record and report, with conclusions. William Wotton, in his defence of the "Modern Methods of Philosophizing", writes :-

"1. No arguments are received as cogent, no principles allowed as current, but what in themselves are intelligible.

2. The Forming of Sects and Parties as Followers of a certain man is discarded. (Condensed).

3. Mathematics joined with Physiology is necessary to understand the economy of Nature. (Condensed).

4. The new Philosophers, as they are commonly called, avoid making general Conclusions, till they have collected a great number of Experiments or Observations upon the thing in hand; and, as new Light comes in, the old Hypotheses fall without Noise or Stir." 32

And he continued:- "Now as this Method of Philosophizing laid down above is right, so it is easie to prove, that it has been carefully followed by Modern Philosophers. My Lord Bacon was the first great Man who took much pains to convince the world that they had hitherto been in the wrong Path, and that Nature herself, rather than her Secretaries, was to be addressed to by those who were desirous to know much of her Mind." "33

Scientific investigation had not yet reached the point of specialization. Robert Boyle, whose experiment was noted above, was really a Chemist, but he made investigations in Physics, Astronomy,

${ }^{31}$ Phil. Transactions. Dec. 16, 1672.

${ }^{22}$ Wotton, William, Reflections upon Ancient and Modern Learning, p. 364.

* Ibid. p. 370. 
and Physiology as well, and even contributed to the Philosophical Transactions, February 22, 1675, an essay entitled "Theological Considerations about the Possibility of the Resurrection". The Philosophers had not yet learned that the whole province of knowledge was too broad. The scope of their studies was, therefore, practically unbounded. Dr. Wallis, a charter member of. the Royal Society, wrote in 1696:-“'Our business was (precluding matters of Theology and State affairs) to discourse and consider of philosophical inquiries, and such as related thereunto; as Physick, Astronomy, Geometry, Anatomy, Navigation, Staticks, Magneticks, Chymicks, Mechanies, and Natural Experiments; with the state of these studies, and their cultivation at home and abroad. We then discoursed of the Circulation of the Blood, the valves in the veins, the venae lactae, the lymphatic vessels, the Copernican hypothesis, the nature of comets, and new stars, the satellites of Jupiter, the oval shape (as it then appeared) of Saturn, the spots on the sun and its turning on its axis, the inequalities and selenography of the moon, the several phases of Venus, and Mercury, the improvement of telescopes and grinding of glasses for that purpose, the weight of air, and the possibility or impossibility of vacuities and Nature's abhorrence thereof, the Torricellian experiment in quicksilver, the descent of heavy bodies and the degree of acceleration therein, with divers other things of like nature, some of which were then but new discoveries, and others not so generally known and embraced as they now are; with other things appertaining to what hath been called the New Philosophy, which, from the time of Galileo at Florence and Sir Francis Bacon (Lord Verulam) in England, hath been much cultivated in Italy, France, Germany, and other parts abroad as well as with us in England". ${ }^{34}$

Some of the new philosophers, however, had well defined interests to which they devoted their best energies. Newton, although interested in theology, was a physicist and mathematician; Ray was a thoroughgoing botanist, as was his intimate friend Willughby; Leeuwenhoek, the Dutch scientist, who was so closely connected with the Royal Society, did his best work in microscopical physiology; Flamsteed was the Royal Astronomer from 1676 to 1719. The day of scientific specialization was dawning, but had

\footnotetext{
* Wallis, John, Account of some passages from his own life. Letter to the Royal Society, 1696.
} 
not yet fully come. In fact, everything was grist that came to the Royal Society's mill. They discussed a universal language, ${ }^{35}$ the power of imagination, ${ }^{36}$ the grafting of oranges, lemons and citrons, ${ }^{37}$ the teaching of Latin ${ }^{38}$ the best method of catching carp, ${ }^{39}$ the means "to facilitate the education of youth",40 considerations about the possibility of Resurrection, ${ }^{41}$ raising tobacco, ${ }^{42}$ and the philosophy of music. ${ }^{43}$ The new interest was practically universal.

The Royal Society early found need for a permanent record of its activities. It was agreed, therefore, that the secretary should prepare a transcript of all papers read before the Society and review new books of interest to science, and should describe the experiments performed at the meetings. As a consequence of this action, Henry Oldenburg, the first secretary, an enthusiastic and self-sacrificing scientist, made ready for publication a complete account of the meetings from the granting of the Royal Charter (1662) to the end of the year, (March) 1665. Oldenburg wrote and published the pamphlets on his own responsibility, the Society merely sanctioning the action. "Whereas 'tis taken notice of, that these Philosophical Transactions are published by the Royal Society, notwithstanding many circumstances to be met with in the already published ones, that import the contrary; the writer thereof hath thought fit, expressly here to declare, that that persuasion, if there be such indeed, is a meer mistake; and that he, upon his Private account (as a well-wisher to the advancement of usefull knowledge and a Furtherer thereof by such Communications, as he is capable to furnish by the Philosophical Correspondency, which he entertains, and hopes to enlarge) hath begun and continues both the composure and publication thereof." 44 It was he who first called these tracts the Philosophical Transactions, by which name they are known today.

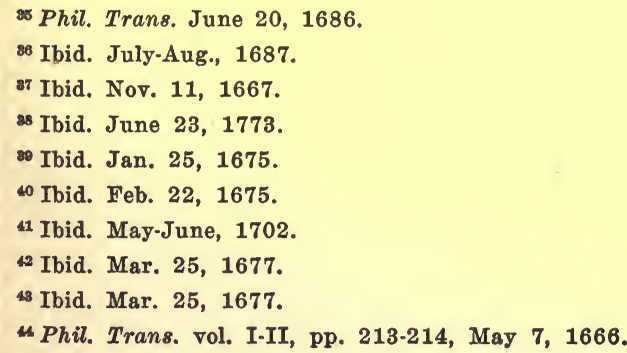


In this depository are to be found a reprint or a digest of the papers read before the Society at its regular meetings, letters received from foreign members or absent correspondents, reviews of books, and at least one drawing to illustrate some important article in each pamphlet. There was no attempt in the early volumes to classify material. The following table of the contents of volume one will show the heterogeneous character;-_"1. An Accompt of the Improvement of Optick Glasses. 2. Observations made in England on a dark Spot in one of the Belts of Jupiter. 3. Experimental History of Cold. 4. A Monstrous Calf. 5. Lead Ore in Germany, used for Essays. 6. Hungarian Balm. 8. Pendulum Watches at Sea." ${ }_{45}$ Here is evidence of an interest in astronomy, metallurgy, physics, and physiology, but there is no systematization, no specialization. It should be noted, however, that much of the investigation is practical, or purports to be.

The appeal in the new science was primarily to curiosity. There arose a desire to know the wonders of the world, to pry into causes of phenomena, to learn of the strange and weird. "The bare prospect of this magnificent Fabrick of the Universe, furnished and adorned with such strange variety of curious and useful Creatures, would suffice to transport us both with Wonder and Joy, if their Commonnesse did not hinder their operations". ${ }^{46}$ Running through the record of this entire period is an obvious interest in the unusual and the marvelous. May 8, 1665, there came a letter from Virginia on a method of killing rattlesnakes; August 16, 1669 , a paper on the "darting of spiders"; December, 1673, a description of "an odd lake in Crimea"; July. 21, 1673, "the effect of thunder on wheat and rye in granaries"; an earthquake September 17, 1683; "A ruminating man", May, 1691; Waterspouts in the Mediterranean, February-May, 1702; "the great frost", December, 1709; the lunar eclipse, February, 1726, etc. And clearly these extraordinary things would eatch the popular attention more quickly than solid learning and profound investigation. The temptation would be for the popular mind to understand these things to be the chief business of the virtuosi, for it is not easy for public opinion to distinguish between curiosity and scientific enthusiasm.

45 Ibid. March, 1665.

4 Boyle, Robert, Usefulness of Experimental Natural Philosophy, p. 3. 
Furthermore, the apparent interest of Charles II from the very beginning gave social prestige to scientific experiments, so that many fashionable gentlemen would assume this virtue, if they had it not. The King had a laboratory equipped in Whitehall, which Samuel Pepys describes. ${ }^{47}$ "It was almost necessary to the character of a fine gentleman to have something to say about air-pumps and telescopes". ${ }^{48}$ But there is nothing here of serious effort or of untiring application, both of which are essential to scientific accomplishment. If these things exist they will be found elsewhere. And so it was, when the movement had lost the first flush of its novelty, when fashionable society had turned its attention elsewhere, then the real workers were left. James II showed no interest; nor did William; Queen Anne was petitioned for aid to furnish the Society with suitable quarters, but she refused. ${ }^{49}$ In 1713 , however, she did send word to the Society that "ministers and governors who go abroad" should make reports of their observations. ${ }^{50}$ George II was asked to become a patron in 1727; he consented, but took no further interest. ${ }^{51}$

From the records it is perfectly clear that the serious scientific work was done by a few men. Several of them were men of means and leisure, as Sir Robert Boyle, Sir Hans Sloane, and Sir Kenelm Digby. The reader of the Philosophical Transactions soon grows familiar with the names of Boyle, Wilkins, Wallis, Hooke, Ray, Leeuwenhoek, Newton, Sloane, and Halley. And it is to be noted in passing that the most of these men are yet famous for scientific achievement. They were not dilettantes; they were students by nature and interest. And, though at times led astray from scientific activity, they were for the most part faithful, untiring, and assiduous. From them came the great discoveries of the period.

Even although the Royal Society itself was born in college halls, yet the universities were on the whole conservative toward the New Philosophy. It was during this period, however, that "Aristotle and the Schoolmen were to be displaced by the influence of

4 Pepys, Samuel, Diary of, May 30, 1667.

4 Macaulay, T. B., History of England, vol. I, p. 376.

40 Weld, C. R., History of the Royal Society, vol. I, p. 388.

o Ibid. vol. I, p. 420, quoted.

Ibid. vol. I, p. 45. 
Bacon and the discoveries of astronomy and physical sciences, and gradually (in the Cambridge schools) questions in moral and natural philosophy took the place of Aristotelian problems".52 There developed in the faculties "some jealousy of the Royal Society, and a prejudice against the work it was doing. Dr. South, the University Orator, at the Encaenia in Oxford in 1669, took occasion to inveigh against it in his satirical vein, denouncing its members 'as underminers of the Universities' ',.53 And there was doubtless some excuse for this attitude, because Dr. Sprat wrote in his apology for the Royal Society,- "I confess there has not bin wanting some forward Assertors of the New Philosophy, who have not us'd any kind of Moderation towards them; But have presently concluded, that nothing can be well done in New Discoveries, unless all the Ancient Arts be first rejected and their Nurseries abolished". ${ }^{54}$

The popularity of courses in science was apparently largely dependent on the instructor. In 1660 Dr. Barrow, Professor of Greek at Cambridge, said;-- "I sit lonesome as an Attic owl, who has been thrust out of the companionship of all other birds; while classes in Natural Science are full." ${ }_{55}$ Likewise, at the end of the century there was Richard Laughton, "the popular pupilmonger", whose classes were large; and the famous blind mathematician, "Saunderson", whose private lectures were well attended. ${ }^{56}$ On the other hand, in the Cambridge classes in Chemistry (1728), "there came as many as twenty-three (the fee being a guinea). Only fourteen came to the fourth course in 1735 ". ${ }^{.7}$

Inevitably, however, the conflict of the old and the new systems would occupy the minds of the professors in the Universities. Learned men were compelled to take sides, and especially the scientists. This controversial spirit was transferred to the students,--if one can accept the following as a fairly representative picture of the college boy; "And in the first place comes home the young pert soph with his atoms and his globuli; and as full of defiance of all country parsons, let them be never so learned and

62 Wordsworth, C., Scholae Academicae, p. 65.

Ibid. p. 194.

Hprat, Thomas, History of the Royal Society, p. 328.

t5 Hettner, Hermann, Englische Literatur, pp. 16-17, quoted.

6 Wordsworth, Christopher, Scholae Academicae, pp. 69-70.

67 Ibid. p. 189. 
prudent, and as confident and magisterial, as if he had been Prolocutor at the first Council of Nice. And he wonders very much that they will pretend to be Gownmen, whereas he cannot see so much as Cartes's Principles, nor Gassendus's Syntagma, lying upon the table; and that they are all so sottish and stupid as not to sell all their Libraries and send presently away for a whole wagon full of New Philosophy. 'I'll tell you, Sir,' says one of these small Whiflers, perhaps, to a grave, sober, and judicious Divine, 'the University is strangely altered since you were there; we are all grown strangely inquisitive and ingenious. I pray, Sir, how went the business of Motion in your Days? We hold it all now to be violent,-' " and so on. The "Whippersnapper's" criticism of the sermon is exquisitely sketched. Then follows a slash at the younger members of Gresham College, who ask "to what purpose is it to preach to people, and go about to save them, without Telescopes, and a Glass for Fleas?" 58

That the new science was being agitated in the universities is clear enough. And the larger ideas were fast being accepted by thinking men. "The study of the New Philosophy, and with it Mathematics generally, had gained some ground at our University (Cambridge) when Sir W. Browne went up there in 1707 . . . . By this time those studies (Principia, Optics, Arithmetica Universalis) were extensively diffused in the university, and copies of the Principia were in such request that in 1710 one which was originally published at ten shillings was considered cheap at two guineas".59 "From the moment of their appearance (Newton's discoveries), they rapidly made their way from one class of thinkers to another nearly as fast as the nature of men's intellectual capacity allows".

The character of the courses offered at the universities may be determined from the following, which is the outline of a series of lectures in Chemistry: "An Encomium on Dr. Friend, the first who applied Newtonian philosophy to Chemistry. Calcinations. Distillation of Hartshorn. Analysis of Plants distilled in the Great Alembic. Distillation of Vitriol. Tincture of Myrrh, Aloes,

\footnotetext{
ss Euchard, John, Observations on the Inquiry into the Grounds and Occasion of the Oontempt of the Clergy, 1671, pp. 142, 147.

6 Wordsworth, C., Scholae Academicae, p. 69.

60 Whewell, William, History of Ind. Science, p. 421.
} 
Laudanum, Steel, and Antimony, and by Digestion. Acids and Alkalis. Experiments of Phosphorus. A short Course on the four Elements." "61

The amount of attention given to seientific studies during this period is shown by these proposed schedules, recommended to new Students by Robert Green, a Cambridge tutor;- "Second Year; Corpuscular Philosophy, Arithmetic, Algebra, (texts; Cartes, Boyle, etc.). Third Year; Experimental Philosophy, Chemistry of Minerals, Plants, and Animals (texts Boyle, Phil. Trans. etc.). Anatomy, Philosophy of Animals, Plants, Vegetables, Minerals, Optics. Fourth Year; Mechanical Philosophy (texts, Boyle, Newton, Halley.) Astronomy (texts, Gassendus, Flamsteed, Newton, etc)."'62

The knowledge of the new Science was disseminated by four different means;-(1) The Philosophical Transactions were on sale at the bookstalls in various places in London, Cambridge, Exeter, Bristol, and perhaps in some towns in Ireland and Scotland. ${ }^{63}$ (2) The students at the universities inevitably came into contact with it in the classroom and in private discussion. (3) Popular lectures were given by various ones of the new philosophers in London. "General diffusion of these opinions took place not only by books, but through the labors of various experimental lecturers, like Desaguliers, who removed from Oxford to London in 1713; where, he informs us, 'he found the Newtonian philosophy generally received among persons of all ranks and professions, and even among the ladies by the help of experiments'.",64 (4) From time to time scientific books were published, when some piece of work had been completed; as Evelyn's Silva, Boyle's History of Cold, Newton's Principles, Hooke's Micrographia, etc. The lay world, at least those who made any pretense to learning, would very likely know the gist of what was being done. It must, however, be observed that the people not directly connected with the scientific activity, would not take the time or the pains,--granting them the ability-to follow thoroughly the researches that were made, or the proofs that were given. As today, the general conclusions, the unusual facts, the weird, the marvelous, the monstrous,--these attracted popular attention.

\footnotetext{
1 Wordsworth, C., Scholae Academicae, p. 189, quoted.

2 Green, Robert, A Scheme for Study, 1707.

- Trail, H. D., Social England, vol. IV, p. 562.

* Whewell, William, History of Inductive Science, p. 426.
} 
Great credit is given by writers to this period for scientific achievement. "There is no period in the history of mankind so distinguished by great and important discoveries or so remarkable for the development of the human intellect as the seventeenth century". ${ }^{65}$ "The age was emphatically an age of Discovery and Invention". ${ }^{66}$ "The human intellect had reached the bounds of the "Wonderland' of Modern Science", ${ }^{67}$ It is now our task to refute or justify these assertions. As stated above, there was no definite specialization at this time. The various fields of science were being surveyed and the boundaries were being defined. It is difficult, therefore, to classify the achievements. For the sake of convenience the following headings have been made: 1. Antiquarianism. 2. Astronomy. 3. Botany. 4. Chemistry. 5. Geography. 6. Mathematics. 7. Physics. 8. Physiology. 9. Mechanical Inventions. The progress made during the period will be traced as briefly as possible.

Interest in Antiquarianism was not a new thing in 1660. As early as 1572 there was a Society of Antiquarians in London. ${ }^{68}$ A "collector of rarities" was the hero of a comedy for the English stage in $1641 .^{69}$ The first great collection of note was begun by John Tradescant, a traveller, who arrived in England about 1600. Under Charles I he was Keeper of the King's Garden. In 1650 he died and left to his son the great collection he had made. The son continued the work of the father and at his death gave the collection to Elias Ashmole, himself an antiquarian and an eminent virtuoso. He in turn gave it to Oxford at his death in 1682, "twelve waggon loads". ${ }^{70}$

The Royal Society also found an interest in collecting rarities. It was voted to pay "fifty pounds to buy a collection of rarities by Mr. Hubbard". ${ }^{71}$ Then, in the last years of the seventeenth century and the early years of the eighteenth, there was aroused a keen interest in the ancient Roman remains in certain parts of

${ }^{65}$ Ency. Brit., Astronomy, vol. 21, p. 220. 15th Edition.

Owen, J., Glanvil's Scepsis Scientifica, Introd. p. XXXIX.

or Ibid. p. XL.

${ }^{68}$ Ency. Brit., Zoology, vol. XXIV, p. 800. 15th Ed. Cf. Leland's New Year's Gift and Bale's Index, and cf. Camden, Selden and others.

* Shackerly, Marmion, The Antiquary, 1641.

70 Weld, C. R., History of the Royal Society, pp. 187-8, 64.

71 Birch, Thomas, History of the Royal Society, vol. II, p. 64. 
England. The first report of these investigations was received by the Royal Society in March, $1683,{ }^{72}$ in a letter read by Martin Lister, who was at the time one of the Secretaries. From this time on the reports are frequent. Many of the gentlemen of leisure found entertainment in this search. From time to time the Royal Society received a number of rarities, and kept them in a room at Gresham College, which Dr. Seth Ward called the "Monster and maggot room". By 1665 the Coffee Houses had began to advertise collections. This was the period also, it must be remembered, of an awakened interest in and an eager search for old and rare manuscripts. Junius published his Anglo-Saxon texts in 1655; Thwaites edited the Heptateuchus in 1698; Hickes's Thesaurus appeared in 1705; Oldys, after years of Antiquarian research, began his edition of the Harleian Miscellany, 1744. These are only indications of a strong undercurrent of scholastic antiquarian interest. There is an interesting account of "the hunt for old books" in the Life of Lady Winchelsea. ${ }^{73}$ Later, Gray and Wharton undertook a history of early English Literature. This spirit of renaissance scholarship united with the new philosophy and developed an interest, largely to be sure for diversion and relaxation, wholly apart from "the bitterness of party" and the disputes of theology.

The impulse toward antiquarian research was due to curiosity. The work was not thorough, nor was it really scientific. "They do indeed neglect no opportunity to bring all rare things of remote countries within the compass of their knowledge and practice. But they still acknowledge their most useful informations to arise from common things, and from diversifying their most ordinary operations upon them". ${ }^{74}$ Careful classifications were made by some of the curators, but except in the case of such men as Ralph Thoresby, Llwyd, and his associate, Dr. Plot, antiquarianism was little more than dilettanteism. The sum total of the work done during this period was to discover some remains of Roman towns and camps, to gather together curious odds and ends from many parts of the world-Jamaica, America, India, etc. The Royal Society received an elephant's tooth, a rattle-snake's skin, a piece

72 Phil. Trans. Feb. 21, 1666.

7s Reynolds, Myra, Wks. of Lady Winchelsea, Introd., pp. XIV, XVII. Cf. Hallam, Introd. to the Lit. of Eur., vol. IV, pt. IV. Chap. I, sec. 2.

it Hooke, Robert, Micrographia, p. 24. 
of petrified wood, the horns of a moose, ${ }^{75}$ etc. The prime incentive here, it is to be noted, is not usefulness.

The best scientific work of the period was done in Astronomy. ${ }^{76}$ This is directly due to the invention of the telescope and apparatus for grinding lenses. From the earliest records of the work of the Royal Society, papers were read on astronomical observations. ${ }^{77}$ Comets were reported; new stars were discovered; the milky way was seen to be a multitude of distant stars; eclipses were accurately predicted. ${ }^{78}$ All scientific men were interested in this work, so that it became fashionable to look at the heavens. Sorbiere found a public telescope when he was in London. "Dans le pare le Roy a fait dresser un grand mast pour des Telescopes, avec lesquels Monsieur de Chevalier Robbert Moray me fit voir Saturne, et les Satellites du Jupiter'".79

It was during this period that the struggle between the old Ptolemaic theory of the cosmogony and the comparatively new Copernican theory came to a final issue. The earth ceased to be the center of the universe, and, like other visible planets, began to move around the sun. What caused them to move? What was the course of their movement? men began to ask. The questions were fully answered and the answer was mathematically demonstrated by the greatest scientist of the period,-Sir Isaac Newton. In him were combined all the elements of the new science. He used the latest and the most improved mechanical apparatus; he tested his own theories by numerous experiments, and urged others to do the same; he demonstrated his conclusions by mathematics. The nobility of his character and the candor of his mind did much to dignify scientific research, and to impress his revolutionary astronomical ideas upon the minds of men.

The leading astronomers of this period were:-Huygens, noted

75 Phil. Trans. July 10, 1683; Nov. 20, 1683; Jan. 20, 1684; April 20, 1684; Dec. 20, 1684 ; May 20, 1685 ; Nov., 1685; Nov.-Dec., 1686 ; Sept.-Oct., 1687; June, 1693 ; May, 1694; Nov., 1697; May, 1698; Sept., 1698; April, 1700; Sept.-Oct., 1700; Feb., 1701 ; Jan.-Feb., 1702 ; Nov.-Dec., 1702; Feb., 1705; Jan.-Mar., 1706; Apr.June, 1711; July-Sept., 1712 ; Jan.-Mar., 1717.

76 Lodge, Oliver J., Pioneers of Science, p. 136.

7 Phil. Trans. Mar., 1665.

${ }^{78}$ Ibid., Apr. 3, 1665; May 8, 1665; Mar. 12, 1666; July 2, 1666; Aug. 14, 1671;

Feb. 21, 1675; Sept., 1699; Sept.-Oct., 1732; Apr., 1733 ; Oct., 1742.

79 Sorbiere, Relation D'Un Voyage En Angleterre, 1669, p. 32. 
for his discovery of the explanation of the rings about Saturn, his pendulum clock, and his micrometer; Robert Hooke, a mechanical genius, who constructed a spring watch, an air-pump for Boyle, and who suggested the law of gravitation; Flamsteed, the Royal Astronomer, whose chief work consisted in the collection of data about the moon; Halley, who experimented with the magic needle, who brought to perfection the "lunar theory"; Descartes, with his new scheme of planetary motion, by means of "vortices"; Newton, with his law of gravitation demonstrated and sustained against all "adversaries"; Bradley, with his "aberration of the fixed stars", and his study of the earth's motion.

The scientific work of the astronomers was of a high character. The whole tendency was to destroy the superstitions of astrology, although there was even yet some extravagance in the claims of knowledge about the moon. "Astrology and Alchemy", wrote Macaulay, "had become jests" Although these pseudo-sciences continued to flourish, ${ }^{81}$ there is not a hint of the old astrological beliefs in the Philosophical Transactions; there is no investigation of the subject. Nor indeed could the new science be other than an enemy of astrology, with its purpose so definitely stated,- to seek "natural" causes as distinguished from supernatural. The contribution to astronomy of this period was solid and substantial, and, while the study may have "silenced the stars", 82 it also expanded the horizon and stimulated the imagination.

"All that was known in the sixteenth and the beginning of the seventeenth century of the phenomena of life in plants was scarcely more than had been learned in the earliest times of human civilization from agriculture, gardening, and other practical dealing with plants. It was known, for instance, that the roots serve to fix plants in the soil and so supply them with food; that certain kinds of manure, such as ashes and, under certain conditions, salt, strengthen vegetation; that buds develop into shoots; and that the blossom precedes the production of seeds and fruit". ${ }^{83}$ But "sys-

80 Macaulay, T. B., History of England, vol. I, p. 378.

81 The famous astrologers were,-William Lilly, Evans, Hart, Captain Bubb, Jeffrey Neve, Dr. Ardee,-Besant, Walter, London in the Time of the Stuarts, p. 162. Cf. also Ashmole's Theatrum Chymicum.

82 Elton, Oliver, The Augustan Age, p. 270.

83 Sachs, Julius von, History of Botany, p. 359. 
tematic botany was begun in the last thirty years of the seventeenth century"'.84 The great names in the study of botany were:-Morison, Grew, Ray, Willughby, Leeuwenhoek, Tournefort, and Malpighi. Morison "helped in the discrimination of genera and got an idea of lineal descent"; Ray and Willughby developed the theory of sex among plants and called attention to striking analogies between plant life and human life, their chief work, however, being a descriptive classification of 18,600 plants (Historia plantarum Generalis); Grew and Malpighi used the compound microscope to study the cellular structure of plants; Tournefort, also a systematic botanist, was the author of Institutiones Rei Herbarias, "without a doubt the best book to appear before the time of Linnaeus"; 85 a long series of his papers are given in the Philosophical Transactions. ${ }^{86}$

With the passing of these men botanical science must await Linnaeus in the second half of the eighteenth century. But the accomplishment during this period was noteworthy. The microscope had been of great aid in discovering the cellular structure of plants, in tracing the flow of sap, and in classifying the species. From 1725 to 1740 the Royal Society received yearly for its repository fifty plants from the Chelsea Gardens. ${ }^{87}$

"The true use of Chemistry", Paracelsus (1493-1541) had said, "is not to make gold, but to prepare medicine". This was still largely the belief, the popular conception of a chemist being either the "sooty Chymist", vainly seeking to transmute the baser metals into gold, or the apothecary. There was, however, a new element contributed by Sir Robert Boyle, i. e., that all chemical changes were due to fire. Add to this the Stahl Phlogiston theory (during combustion phlogiston, the inflammable element, makes its escape, and is the cause of light and heat), and the great contributions to Chemistry in this period end. But there is a new attitude in chemical investigation, as elsewhere. The new science tended to destroy alchemy ${ }^{88}$ as the new astronomy tended to destroy astrology. Ben

84 Ibid. p. 66.

85 Thomson, T., History of the Royal Society, p. 33.

${ }^{86}$ Phil. Trans. Aug.-Sept., 1674; Aug.-Sept., 1675; June, 1683 ; Feb., 1685; JulyAug., 1693; Sept.-Oct., 1694, etc.

${ }^{87}$ Cf. Phil. Trans. 1725-40.

${ }^{88}$ Ency. Brit., Chemistry, 11th Ed. Cf. Ashmole's Theatrum Chymicum; Hathaway's The Alchemist, Introduction. 
Jonson's satire was no longer pertinent for the new scientists. The Royal Society never sought for the Philosopher's Stone.

The spirit of travel and exploration was active in this period. Dampier's Voyages is a conspicuous example. And, not only did Sorbiere, Moncony, Evremont, Voltaire, and other foreigners visit England for purposes of inspection, but many Englishmen likewise returned the compliment. Ray, Willughby, Lister, Thoresby made journeys to the continent to gather data for the new natural history; Halley sailed to South America to make astronomical observations; Sir Thomas Browne made a tour of discovery into Iceland. The later archaeological investigations of Lord Montagu in the far East are well known. Connected with this interest was a desire to make accurate geography. The work of the Sansons in France is perhaps the most important. Helvelius's map of the moon, inspired of this same spirit, furnished a good mark for the satirists. Related to the geographical interest is the study of the structure of the earth itself. Geology had not yet really begun, but the work of Woodward is noteworthy. He endeavored to explain the presence of sea fossils found far inland on the basis of Burnet's Sacred Theory. ${ }^{89}$ At the time of the deluge, he claimed, the waters pent up within the crust of the earth burst their bounds, and when the various substances again settled to the layer where their varying weights carried them, these fossils were thus displaced. The explanation was ingenious but not convincing even to his contemporaries. ${ }^{90}$ It may now be seen, however, that Woodward narrowly missed discovering the strata of the earth's crust, the great achievement of the following years.

In mathematics there was great activity through these years. As has been shown, Descartes brought this pure science to the aid of philosophical problems, making it the handmaid of astronomy and physics. There could, however, be little to attract the popular mind developed from its study. There was a dispute that lasted for several years between Descartes, Hobbes, Wallis, and others, over the possibility of squaring the circle; and Newton and Leibnitz quarreled over their respective claims to priority in the invention of

${ }^{80} \mathrm{Cf}$. Woodward's Account of the Deluge.

${ }^{80}$ Cf. Arbuthnot's An Examination of Woodward's Account of the Deluge, Wks., vol. II, p. 196. 
differential calculus. ${ }^{91}$ The great names in mathematics were:Descartes, Wallis, Wilkins, Isaac Barrow, and Newton. There is no great service that it performed alone, but it entered vitally into the new study of astronomy, physics, and scientific calculations generally.

The study of physics was pursued with great vigor, and the accomplishments were noteworthy. There were experiments made of falling bodies, of heat, light, cold, color, of atmospheric weight, of elasticity of air, of magnetism, and, growing more frequent in the last years of the period, of electricity. ${ }^{92}$ The great names in this science were;-Descartes, Boyle, and Newton. Descartes developed his "vortex theory" of motion; Boyle discovered the law of the compressibility of air that bears his name; Newton, by means of mathematical demonstration, established the law of gravitation, and explained the phenomenon of prismatic colors. There was, furthermore, considerable interest in navigation; Charles II performed some experiments in this branch of science in his laboratory at Whitehall. ${ }^{93}$ This interest lead to experiments with the compass, and hence with magnetism. "The greatest Modern Inventions seem to be," said Sir William Temple in defense of ancient learning, "those of the Load-Stone and Gun-powder". ${ }^{94}$ And then Hauksbee began in 1705 a series of interesting electrical experiments which culminated in the work of Benjamin Franklin, whose letters were received by the Royal Society in 1746 . The period is clearly fruitful in discoveries and the tendency is towards things of practical use.

The study of living bodies was greatly stimulated by Harvey's discovery of the circulation of the blood, and was augmented by the invention of the microscope. "By means of the Telescopes, there is nothing so far distant but may be represented to our view; and by help of the Microscopes, there is nothing so small, as to escape our inquiry; hence there is a new visible world discovered

91 Phil. Trans. Mar. 16, 1668; Apr. 13, 1668; Feb. 5, 1669; June 21, 1669. Cf. Arbuthnot's Advantages of Mathematical Studies and Berkeley's New Arithmetic.

${ }_{22}$ Phil. Trans. Mar. 6, 1665; Nov. 15, 1669; June 17, 1672; July 15, 1672 ; Nov. 8, 1672; Feb. 28, 1673; Jan. 24, 1676; Jan.-Feb., 1707; May-June, 1708; Oct.-Dec., 1714 ; Nov.-Dec., 1732; April-June, 1736; July-Oct., 1739; Jan.Feb., 1741; Jan.-Feb., 1742.

Pepys, Samuel, Diary, 1665, Jan. 15, 1668-9.

94 Temple, Sir William, Miscellanea, pt. I, Some Reflections, etc. 
to the understanding". ${ }^{95}$ This was the period of the beginning of histology and anatomy, with the descriptions of bone structure, of blood composition, of valves in the veins, etc. There were experiments in respiration, in the structure of the skin, and particularly with medicinal plants. ${ }^{96}$ "A garden of medical plants was created by the Company of Apothecaries as early as 1673, and it was greatly improved in the early years of the 18th century, chiefly through the influence of Sir Hans Sloane"'.97 It is claimed that Leeuwenhoek really discovered the existence of bacteria by means of his microscopes. ${ }^{98}$

Many of the members of the Royal Society were physicians, who willingly accepted "the new Method of Philosophizing". Their interest concentrated all biological investigations upon their relationship to medical practice. This, however, does not seem to have been greatly improved. "Medical science had been somewhat improved, but the practice of lowering the constitution by excessive bleedings was so general that it may be questioned on the whole whether it did not kill more than it cured". ${ }^{99}$ Surgery, which was differentiated from the practice of medicine, was not changed appreciably by the new science. It continued cruel and crude until the discovery of anaesthetics. Perhaps the most striking single thing in medical science during this period was the introduction of inoculation against small-pox, in which Lady Mary Wortley Montague took such an important part.

Medical superstitions still persisted through this period. Sir Kenelm Digby, a charter member of the Royal Society, believed in the power of sympathetic powder $;^{100}$ Robert Boyle defended the mysterious power of "Amulets, or other external Remedies" ;101 Richard Wisemann, Surgeon-General to Charles II, assisted at cures of scrofula by royal touch. ${ }^{102}$ Elias Ashmole was an adept in Rosicrucian mysteries. It was the period of the famous Great-

\footnotetext{
${ }^{95}$ Hooke, Robert, Micrographia, Preface, p. 9, 1665.

${ }^{86}$ Lecky, W. E. H., England in the Eighteenth Century, vol. I, pp. 621-2.

87 Ibid. vol. I, p. 622.

${ }^{98}$ Phil. Trans. 1675.

${ }^{99}$ Lecky, W. E. H., England in the Eighteenth Century, vol. I, p. 621.

100 Phil. Trans. April-June, 1714.

101 Boyle, Robert, Usefulness of Natural Experimental Knowledge, p. 238.

102 Trail, H. D., Social England, vol. VI, p. 46.
} 
orix. "Boyle, Henry More, Meric Casaubon, Baxter, Cudworth all believed fully in witcheraft". ${ }^{103}$ But even then all these beliefs were considered vagaries. The influence of the new science was consistently and strongly to destroy all such untenable and undemonstrable theories. The quack doctor still continued to exist and no doubt to flourish, but he was neither created nor nutured by the new philosophy. What, indeed, could be more fatal to medical chicanery than the requirement to explain by natural causes the origin of diseases and their cures? In medicine, as in Chemistry and Astronomy, false doctrines were being broken down. What had been a secret and magical art was fast becoming an open and sensible science. The most famous physician among the new philosophers and the great exponent of commonsense in medical practice undoubtedly was Sydenham.

Mechanical inventions were always included within the realm of scientific investigation. There were two reasons for this; first, because these inventions were for the most part laboratory apparatus or the direct result of laboratory experiments; second, because the Royal Society had specifically declared its intention "to improve all useful Arts, Manufactures, Mechanick Practices, Engynes and Inventions by Experiments". ${ }^{104}$ They were satirically known as "Physico-Mechanical Inventions". ${ }^{105}$ The list is not an unworthy one; indeed, surprises one in its extent. To this period should be attributed the improved telescopes for the new methods of grinding glasses revolutionized this invention. The microscope belongs here for the same reason; the Torricellian barometer was at this time first understood and used; a primitive thermometer came out of the experiments with mercury; the compass was improved; the pendulum clock was made so as to avoid variations on the sea; the spring clock was invented; a magic lantern of a crude sort was made; the air-pump was contrived by Robert Hooke under the direction of Boyle; asbestos was manufactured; and a weaving loom was constructed. ${ }^{106}$ Both Wilkins and Hooke thought they

${ }^{103}$ Owen, J., Glanvil's Scepsis Scientifica, Introd., p. XLIV.

104 Supra, p. 6.

105 Shadwell, Thomas, The Virtuoso, Act. I. sc. 1.

108 Phil. Trans. Mar. 6, 1665; June 5, 1665 (M. Auzout, On Telescopes); Feb. 12, 1666 (Barometer); Oct., 1798 (Magic Lanthorn); March 11, 1666 (rarifying engyn); also, Nov. 22, 1675 ; Dec. 27, 1675; Feb. 21, 1676; Aug.-July, 1678. Savery's steam engine doubtless belongs here in the list (1698). 
had a method that could be made practicable by which men could fly. Besides all these there must have been scores of abortive attempts. Lord Worcester's A Century of Inventions contains hundreds of wild-eyed schemes for doing useful and extraordinary things by mechanical contrivances.

From the foregoing facts it is clear that the new philosophers were sincere in their stated purpose to be practical and to make their knowledge useful. This learned group of men did not consider it beneath their dignity to give up a meeting to the discussion of a new kind of "bee-house" 107 or to a consideration of new agricultural implements. ${ }^{108}$ Sir Robert Moray devoted one entire letter to the Royal Society from Hungary to the description of a new kind of airshaft for ventilating mines. ${ }^{109}$ There was a drawing of a proposed speaking trumpet given Sept.-Nov. 1678. An article found a place in the Philosophical Transactions on preserving ice and snow by covering them with chaff. In the copy for March 25, 1669 , on an equal basis with a new instrument for drawing an object in perspective, observations of Saturn, and a paper by Lower on the motion of the heart, is a letter from France on melons, the best varieties and how to raise them. Certainly the new philosophers did not despise the day of small things, and certainly they desired to be practical, and however many of them were drawn aside, and however far, into wild vagaries and the following of false lights, the sum total of their efforts is a noble achievement.

The movement has been defined, and its progress has been traced through the period, with some account of the activity in the various fields of interest. A general survey, therefore, should show the scientific ideas revealed to the world by this company of experimenters. They preached, in the first place, a new scientific attitude of mind that was fundamental and far-reaching, and that would affect the mode of thinking of all men who came in contact with it. It was an insistence upon absolute intelligibility in philosophical discussions,-a "working upon Intelligible Principles in an Intelligible Manner". The first element of Descartes's method "was to accept nothing as true which I did not clearly recognize

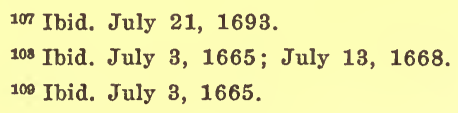


to be so". "No arguments are received as cogent, no principles allowed as current, but what in themselves are intelligible". ${ }^{110 *}$ The point can hardly be over-emphasized, for the influence of this insistence is pervasive. It is a demand for commonsense and reasonableness in all thinking. This is the attempt "to get a true relation between form and substance", 111 as found in English prose style of the time. And not only is intelligibility insisted upon, but carefulness alșo. There must be an accumulation of data, a course of experiments, a period of preliminary thinking, an avoidance of snap-judgments and broad generalizations. Finally, this is the period of practical knowledge; learning must tend to some useful purpose if it is to be worth while.

Out of the scientific activity came certain new ideas affecting man's conception of the physical world. Newton wrote in his System of the World (1689) a new description of the heavens and the earth, showing the position and the motion of the planets, and their relation to the sun, and gave a new conception of the infinity of space. He also explained the phenomena of colors and analyzed the rays of light. The air was found to be a substance, with weight, compressible, expansive, a thing of interest, comprehensible. The microscope revealed a new world of minutiae, and raised to a plane of dignity in the minds of the scientists, the meanest creatures. Even the least were found to be fearfully and wonderfully made. The structure of objects generally was studied,- the bark, the fruit, the sap of plants. Then came the larger idea that they belonged in great families. The telescope, likewise, stimulated the imagination by extending the horizon, by discovering countless multitudes of stars in the "infinite meadows of the heavens"; while mathematics demonstrated the order and beauty of their motions. Comets lost their mystery, eclipses were explained, selenography was written, the sunspots observed. In a new sense the "heavens were declaring the glory of God and the firmament showing His handiwork". With this expanding horizon came a

110 Wotton, supra, p. 12.

111 Elton, Oliver, The Augustan Ages, p. 420.

* That an idea should become intelligible to the New Philosophers it must "have in some sense a Mechanical Conception." Oldenburg, Henry, Phil. Trans. vol. XVII, Preface. 
sense of man's insignificance; but the human body received its attention. The course of the blood was traced completely when the microscope discovered the capillaries. The structure of the eye, of the skin, of the bones, was investigated, and the function of the lungs in respiration. Some conception was gained of the existence of ether, of oxygen, of the wonderful power of magnetism and electricity. There was a crude effort to apply the force of steam to mechanical uses. Some notion of past races was secured from their remains, though sought largely through curiosity. And finally, through the system of correspondence established by the Royal Society, a feeling of unity of interest drew the nations of Europe nearer together. "It was not till now that the notion of 'Europe, as for intellectual purposes, one great confederation', could be said to glimmer before the modern mind". ${ }^{112}$

112 Elton, Oliver, The Augustan Ages, p. 420. 


\section{CHAPTER II \\ The Conflict of Old and New Ideas}

The new philosophy, as an intellectual impulse, entered all avenues of thought, but not without opposition. It was challenged in turn by prejudice, inherited belief, and accepted authority. Bacon had early bid defiance to the scholastic authority; "the real beginning of English philosophy is to be dated from Bacon's break with scholasticism". But to carry on the struggle to certain victory was left to his disciples. The second step was for the new-science to free itself from the domination of theology, "to assert the freedom of the scientific intellect". This was done by the valiant little group of men at Gresham College, who formed the nucleus of the Royal Society. They pledged themselves to avoid the problems of "Divinity, Metaphysicks, Moralls, Politicks, Grammar, Rhetoric, and Logic" ; ${ }^{2}$ they "set themselves to read in the Great Book of Nature, to walk in its Garden and taste its plenty, instead of idle talking and wandering."

With their field of inquiry thus bounded and with their "reason free and unpossest", the new philosophers were ready to search for the truth by means of experiment and observation, and to lay the broad foundations for the new natural history of the world. The reward of their effort was almost instantaneous; flushed with the triumph of discovery, they entered the "wonderland of modern science" as revealed by the telescope and the microscope. And they naively expressed their hope that "as new Light comes in, the old Hypotheses will fall without noise". 3 But this was, of course, psychologically impossible, for old hypotheses, especially those which concern personal faith, do not yield in silence. "The gradual ebbing of an ancient faith leaves a painful discord between the imagination and reason. The idols gradually lose their sanctity; but they are cherished by poets long after they are disowned by philosophers, and the poet has the greatest immediate influence with the many." It is this "painful discord" in the period of

1 Seth, James, English Philosophers and Schools of Philosophy, p. 10.

${ }^{2}$ Wallis, John, Account of Some Passages in my Life, 1696.

Wotton, William, Reflections, p. 364.

- Stephens, Leslie, History of English Thought, vol. I, p. 16. 
transition, this effort of the mind to measure itself with a new rule of reason and commonsense, this struggle of the imagination to adjust itself to new imagery, which forms the subject of this chapter. Those men of literary genius who were brought into intimate contact with the new philosophy in its full encounter with the traditions of ancient faith will here be discussed.

The transition from the old to the new attitude is well illustrated in the writings of Sir Thomas Browne. The Religio Medici (1635-6) was written under the domination of the "ancient faith" There is found in it a frank avowal of the old spirit of acceptance, the attitude of non-reason against which the new philosophers revolted. "I believe all this (divine mysteries) is true, which indeed my reason would persuade me to be false; and this $I$ think is no vulgar part of Faith, to believe a thing not only above, but contrary to reason, and against the arguments of our proper senses". 5 Besides this quiescence of reason in The Religio Medici there is also the old physical conception of the world. "To make a revolution every day is the nature of the sun, because of that necessary course which God ordained it, from which it cannot swerve but by a faculty from that same voice which did first give it motion". "Astrology, although curiously modified, also finds expression here. "We need not labor with so many arguments to confute Judicial Astrology; for if there be a truth therein, it doth not injure Divinity; if to be born under Mercury disposeth us to be witty; under Jupiter to be wealthy; I do not owe a Knee unto those, but unto that Merciful Hand that hath ordered my indifferent and uncertain Nativity unto such benevolous Aspects"'? Many of the old beliefs are here in more or less direct form. "For my part, I have ever believed, and do now know, that there are Witches".8 "I conceive there is a traditional Magick, not learned immediately from the Devil, but at second hand from his Scholars". "Therefore, for Spirits, I am so far from denying their existence, that I could easily believe, that not only whole countries,

5 Browne, Sir Thomas, Religio Medici, vol. I, p. 18.

Ibid. vol. I, p. 25.

7 Ibid. vol. I, p. 30 .

8 Ibid. vol. I, p. 45.

- Ibid. vol. I, p. 46. 
but particular persons, have their tutelary or Guardian Angels". ${ }^{10}$ Nor had the stars yet been silenced for him: "For there is a Musick wherever there is harmony, order, or proportion; and thus far we may maintain the Musick of the Spheres". ${ }^{11}$ This frank adherence to the old doctrines is given, although the new ideas were not unknown to him. While Browne writes in the terms of the old astrology, for instance, the new astronomy is familiar to him. "I conclude, therefore, and say, there is no happiness under, or (as Copernicus WILL have it, above) the sun". ${ }^{12}$

It may be seen, therefore, that Sir Thomas Browne has given his allegiance to the old faith. There is only a faint hint of "the freedom of the scientific spirit" in the Religio Medici. So equivocal, however, is his position on certain points that the reader suspects the mind of the man to be outgrowing the "ancient faith"; but nowhere in this book does he take the new attitude. The new mental impulse was yet to come to him, the impulse destined to destroy entirely the attitude of non-reason and most of the beliefs in this book.

The ten years from 1635 to 1645 made a radical change in the point of view of Sir Thomas Browne. Early in the Vulgar Errors (published in 1646) the most typical characteristic of the new philosophers finds expression;-namely, a defiance of ancient authority. "But the mortalest enemy unto knowledge, and that which hath done the greatest execution upon truth, hath been the peremptory adhesion unto authority, and more especially of our belief upon the dictates of Antiquity"'. ${ }^{13}$ Against the unqualified acceptance of the "dictates of Antiquity" Browne finds seven reasons, which any member of the Royal Society would have endorsed. 1. Men impose a thraldom upon their times by too great reverence for antiquity. 2. The ancient times were once present times (from Bacon himself). 3. The testimonies from antiquity are not always exact. 4. The fabulous condition of the accounts should be considered. 5. Men applaud merely ordinary things in the Ancients. 6. Men argue the authority of the Ancients on points that do not

\footnotetext{
10 Ibid. vol. I, p. 48.

11 Religio Medici, vol. I, p. 100.

12 Ibid. vol. I, p. 111.

13 Vulgar Errors, vol. I, p. 152.
} 
need it. 7. Men have already deserted antiquity on some things. ${ }^{14}$ These are strange words from the pen of the author of the Religio Medici; they voice a mental attitude in perfect accord with the founder of the new experimental philosophy. "Bacon's protest against the principle of authority is no less vigorous than that of Descartes". ${ }^{15}$

But not only has this philosophical physician largely the mental attitude of the new scientists, he has also an active interest in the reconstruction of the new natural history. For, first of all, the aim in writing Vulgar Errors was to correct false notions that had found lodgment in the minds of the common people. ${ }^{16}$ The author becomes here a true virtuoso, testing by experiment and observation these long accepted theories, and reporting with care the facts and his conclusions. "No metal attracts, nor animal concretion we know, although polite and smooth; as we have made trial in Elk's hoofs, Hawk's Talons, the sword of the Sword-fish, Tortois-shells, Sea-horse, and Elephant's teeth, in Bones, in Harts-horn, and what is usually conceived Unicorn's horn', ${ }^{17}$ This reads like a report to the Royal Society, and shows beyond a doubt that Sir Thomas Browne was by this time, both in attitude and method, one of the new philosophers. The "divine mysteries" were no longer accepted on faith, but must be "strongly erected upon the two great pillars of truth, experience and reason". ${ }^{18}$ In the same manner he proceeded to explain by natural causes the noise of the Deathwatch, ${ }^{19}$ and to prove that "crystal is not concreted Ice or Snow" ${ }^{20}$ It was he who found the natural cause for "the raining of wheat from heaven", which created so much excitement among the virtuosi at Gresham College. "1 "What was found this year in many places and almost preached for wheat rained from the clouds, was but the seed of the ivy-berries, which somewhat represent it"..22

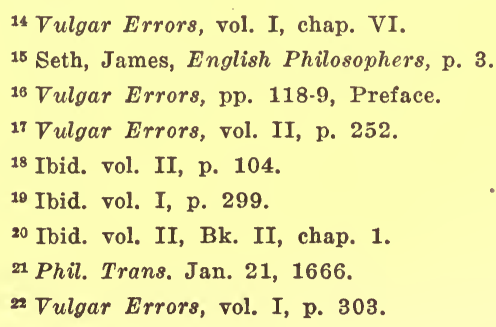


The vulgar error that "a Dove or Pigeon hath no gall" seemed to him repugnant to experience, for "anatomical enquiry discovereth in them a gall". ${ }^{23}$ Furthermore, he had made experiments with glow-worms; he had tested distilled waters; he was familiar with and approved Helvelius's selenography ${ }^{24}$ he was acquainted with the conflicting theories of magnetism as pronounced by Descartes ("whether these effluviums do fly by striated Atoms and winding particles as Renatus Descartes conceiveth" ${ }^{25}$ ) and by Sir Kenelm Digby (" or glide by streams attracted from either Pole and Hemisphere unto the Equator as Sir Kenelm Digby excellently declareth" ${ }^{26}$ ). To his judgment there was sufficient proof for the acceptance of that curious theory,-likewise listened to with much respect by the Royal Society-that music had great power over Tarantulas. The citation will serve as an illustration of how strong "the two great pillars of truth, experience and reason," must be to support belief. "Some doubt many have of the Tarantula, or poisonous spider of Cabbria, and that magical cure of the bite thereof by Musick. But since we observe that many attest it from experience; since the learned Kircherius hath positively averred it, and set down songs and tunes solemnly used for it; since some also affirm the Tarantula itself will dance upon certain strooks whereby they set their instruments against its poison; we shall not at all question it"'.27

There is reason for surprise that Sir Thomas Browne was not elected Fellow of the Royal Society, for he was much respected among the new scientists, as proved by their request that he should write for them an account of Iceland whither he had travelled. ${ }^{28}$ For years, also, he was actively interested in antiquarian researches in England. The results of his investigations are found in The Urn Burial, Brampton Urns, and many of his miscellaneous tracts. In all of this effort he was helping in the work of reconstructing the natural history of the world.

From the foregoing discussion it is evident that Sir Thomas

29 Ibid. p. 317, 318.

24 Ibid. vol. II, p. 99.

${ }^{25}$ Ibid. vol. II, p. 398.

${ }^{26}$ Vulgar Errors, vol. II, p. 218.

27 Ibid. vol. II, p. 106.

${ }^{28}$ An Account of Island, alias Iceland, at the Request of the Royal Society. 
Browne had been thoroughly converted to the new scientific attitude, and that he must have relinquished many an old theory which could not adjust itself to experience and reason. And yet to the last he clung to certain old beliefs that were rapidly yield ing before the attack of the new science. Concerning astrology he wrote;-- "We do not hereby reject a sober regulated astrology. . . . . We do not deny the influence of the stars". ${ }^{29}$ He still held to the Ptolemaic system;- "And first we can not pass over His Providence, in that the sun moveth at all, for if it stood still, and were fixed like the earth, there had been then no distinction of time, either of day or year, of Spring, of Autumn, of Summer, of Winter". ${ }^{30}$ He continued to believe in omens and portents, and in general evaded the whole Copernican Theory. ${ }^{31}$

Sir Thomas Browne has been treated with some minuteness because he represents so clearly the struggle between the old and the new beliefs during this transitional period. He was, in the first place, a physician and was brought by his profession into close contact with the new scientific inquiries. In the second place, he was gifted with imagination and felt an impulse to give literary expression to what he thought and felt. His experience will serve as a type in prose for this early period,- - the transition from the old science to the new, the breaking down of vulgar errors such as traditions, superstitions and "romantic stories", and the establishing of a new system of truth founded on the two great pillars, experience and reason.

Across the minds of the poets who were brought into direct contact with the new philosophy, there fell the sudden light of the new discoveries. "Every atom became a standing miracle" through the lenses of the microscope; and the old heaven and the old earth passed away before the telescope. The old physical imagery grew obsolete; the conceptions of the old science became outworn. In this period, "when the traditions of the ancient faith met in full encounter with the forces of the new philosophy", poetic imagination was struggling to adjust itself to new conditions. This literary phenomenon is illustrated in the work of Cowley, Waller, Den-

\footnotetext{
${ }^{29}$ Vulgar Errors, vol. II, p. 200.

30 Ibid. p. 318.

31 Ibid. vol. II, p. 194; vol. II, p. 318.
} 
ham, the Duchess of Newcastle, Milton and Dryden. ${ }^{32}$ The problem presented is two-fold;-(1) To what extent the poets were influenced by the new ideas, and (2) how adequately they gave literary expression to them.

Cowley was early an ardent advocate of the new scientific inquiries, and took an active part in their encouragement. Like Milton and Evelyn, he was interested in educational reform and published in 1661, A Proposition for the Advancement of Learning. This is a prose essay in which the author has outlined specifically a plan for a new technical school. He has even given the number of instructors to be employed and the salaries to be paid them, and the number of students to be enrolled. By means of this institution he hoped, according to the preface, to encourage "the inquisition into the nature of God's Creatures, and the application of them (principles discovered) to Humane Uses (especially the latter".) ${ }^{33}$ It may thus be seen that Cowley was brought fairly into contact with the new science; he knew its method, its spirit of inquiry, and its early achievements.

The passages in his poetry, however, that reveal any influence of the new philosophy are surprisingly few. Such admiration as he expressed was for the character and work of Bacon and Harvey. In his Ode to the Royal Society, he praises Bacon for his revolt against the power of ancient authority.-

"Authority . . . . . . . made

Children and superstitious men afraid,

The orchard's open now and free;

Bacon has broke the Scare-crow Deitie". ${ }^{34}$

This great scientist, like another Moses, has led men forth from the bondage of scholasticism; like a new star that "does to Fools a Meteor show", he has added new beauty to the heavens. But through all the extravagant flattery of this "unnavigable" poem, one may clearly see that the quality in the work of Bacon which Cowley best understood and by which he was most attracted was not

Courthope, W. J., History of English Poetry:- "No more lively or characteristic representative can be found of the thought of an age when the traditions of an ancient faith met in full encounter with the forces of the new philosophy".-On Donne, vol. III, p. 168.

3 A Proposition for the Advancement of Learning, Preface.

at Ode to the Royal Society. 
his widening of the physical and intellectual horizon, but "his candid stile". Bacon's style, however, influenced him only in his "Montaigne-like" essays. ${ }^{35}$

Harvey's physiological discoveries aroused Cowley's admiration which found a somewhat awkward expression in an Ode to Dr. Harvey. There is in these lines a curious attempt to adapt the old classical imagery to these new scientific ideas. The effect is almost grotesque. Harvey's search for truth in nature is compared to the pursuit of Daphne and to Jason's journey after the golden fleece; his great discovery of the circulation of the blood is the capture of a modern Proteus;- "Held the slippery Proteus in chain". ${ }^{36}$ The clearest and strongest lines in the poem describe the new process of investigation.-

“'Thus Harvey sought for truth in truth's own book,

The Creatures, which by God himself was writ;

And wisely thought 'twas fit,

Not to read Comments only upon it,

But on the Original itself to look". ${ }^{37}$

All in all, it is a poor showing that the new science makes in Cowley's verse. Where an attempt is made to give poetic expression to the new ideas the lines become awkward and "unnavigable", or else they are conventional, and classical imagery obscures them. No new vision of the heavens has come to him through the telescope; the "crowds of golden globes on high", 38 the milky way, the falling meteors, "gilding the passage as they flie", were all beheld by poets before the advent of the new science. Cowley's mind was fettered by classical and out-worn imagery, but clearly also his imagination was struggling to harmonize that "painful discord" with reason. The sum of his expression of the new philosophy, "the great and only heir of all the Ages", is the encouragement of interest and enthusiasm, a few awkward attempts at literary expression, and a scant half dozen new images.

Three other poets belong in the same group with Cowley. They, too, held over from the old regime and came late to the new point

${ }^{36}$ Gosse, Edmund, History of 18th Century Lit., p. 77.

O Ode to Dr. Harvey, st. 2.

s7 Ibid.

${ }^{2}$ Cf. Ode to the Royal Society, Clad in White, Reason, Maiden-head. 
of view. They, too, were intimately connected with the new scientists. Edmund Waller was elected to a fellowship in the Royal Society, and must, therefore, have evinced considerable interest in the new scientific research. But the effect of the new discoveries upon his mind was slight. A rather striking figure came to him from Descartes. "Besides their verses ran all into one another, and hung together, throughout the whole copy, like the hooked atoms that compose a body in Des Cartes". ${ }^{39}$ The physical imagery in his verse is almost always that of the old science; there are "the rolling planets and the glorious sun",40 "the influence of the stars", 41 and "the bright stars and milky way".42 A few items of scientific news he had gleaned, however, such as the newly discovered sunspots, the motion of the earth, ${ }^{43}$ and the cause of the winds. ${ }^{44}$ But not even these ideas are used with consistency. What a meagre expression is this for a poet who lived through those years of splendid scientific development from 1660 to 1680 . He may have come too late to adjust himself to the new ideas; certainly he was not inspired by them.

Denham, likewise a Fellow of the Royal Society, touched upon the new material in only one poem, The Progress of Learning. $\mathrm{He}$ manifested in these lines little confidence in the firm foundation that was being laid for a new natural history.

“Through seas of knowledge, we our course advance,

Discovering still new worlds of Ignorance,

And those discoveries make us all confess

That sublunary Science is but guess.

Matters of fact, to man are only known,

And what seems more is meer opinion." 45

This, then, was the boasted progress that learning had made through the ages; this was the kind of knowledge which "like the blood, must circulate"! All attempts to "anatomize the truth into

so Waller, Edmund, Poems, pt. II, Preface, p. XXI.

40 On the Fear of God, canto II, 1. 23.

41 Instructions to a Painter; the Presage of Rain.

12 The Night Piece.

4 Divine Love, canto IV, 15-18.

4 Divine Poesy, canto II, 15-16.

45 The Progress of Learning. 
Atoms" must needs be in vain. There is for Denham no inspiration in the new philosophy. The dearth of new ideas in his lines is striking. From all the discoveries of science he had caught these two figures; besides, in an abstract way, man's body had become to him a "microcosm" of the new philosophy. The influence of the new science upon him is negligible; the attempt to give poetic expression to what he must have known is slight. He did not, or could not, adjust himself to the new conditions.

Another member of this group, though remarkable in many ways, may be dismissed with a few words. The Duchess of Newcastle found an insatiable interest in philosophy. It is known that she once paid a visit to the Royal Society, a fact which caused a great flutter in London social circles. ${ }^{46}$ Long before this she had made up a fairly complete system of philosophy, for herself (1655). Her method was simple in the extreme. She took from Descartes and Hobbes the two fundamental principles of all creation outside of man himself, matter and motion. She held, therefore, that all physical forms were made by an infinite variety of motion. An animal would, according to her system, differ from a stone because of the different motion of the particles that compose the bodies. There was, also, the "innate" motion which gave life and spirit to men. It is, however, impossible to take her seriously. She has characterized her own mind as aptly as any satire could do it: "I dance a measure with the Muses, feast with the Sciences, or sit and discourse with the Arts". ${ }^{47}$ Not in such a manner can either the arts or sciences be advanced, nor thus can the Muses be highly honored. The Duchess was, in fact, merely an indefatigable scribbler; her mind was "ever bubbling over with phantasies". "Doctor", said the Duchess of Newcastle to Wilkins regarding his Discovery of a New World, "where am I to find a place for baiting at, in the way up to that planet?" "Madam", replied Wilkins, "of all the people in the world, I never expected that question from you, who have built so many castles in the air, that you may be every night at one of your own"..48

\footnotetext{
46 Pepys's Diary, May 30, 1667.

${ }^{47}$ Duch. of Newcastle, The Philosophical and Physical Opinions of, 28.

« Burnet's History of his own Times, p. 128.
} 
In her essay on philosophy and physics she has interpolated versified passages. One sample is enough.

"The Earth, Sun, Moon, the rest of Planets all

Are moved by that, we Vitall Spirits cal.

And like to Animals, some move slow,

And other some by quicker motion go.

And so some Creatures by their shapes do flye,

Some swim, some run, some creep, some riseth high.

So Planets by their shapes about do winde,

All being made, like Circles, round we finde." ${ }_{49}$

Aside from these uninspired attempts, her verse contains the most conventional imagery. She was obviously eager to learn the new philosophy, she was highly delighted with the experiments which the Royal Society performed for her; but she did not contribute anything toward the literary interpretation of the new science. On the contrary, she offered a splendid target for the "Wits and Railleurs".

This struggle between the old and the new ideas was also in the mind of John Milton, the belated Puritan. In his university days he was taught the old Ptolemaic doctrines which were held by both Cambridge and Oxford at that time. ${ }^{50}$ That his imagination first built upon the old physical conceptions can be demonstrated from his early poems. ${ }^{51}$ Behind The Hymn of the Nativity, The Arcades, and Comus lie the old scientific beliefs. It is true that much freedom should be granted the poet in the matter of poetic imagery; "he cherishes the old idols long after they have lost their sanctity and have been disowned by philosophers". The poetic use of Greek and Roman myths does not postulate an acceptance in the poet's mind. And yet, such lines as the following show an undistrubed confidence in the old science.

"When the sons of the morning sung,

While the Creator great

His constellation set,

And the well-balanced world on hinges hung. ${ }^{, 52}$

\footnotetext{
${ }^{40}$ Of the Motion of Planets, Phil. and Phys. Opinions, p. 24.

${ }^{50}$ Masson, David, Life of Milton, vi, p. 534.

Ibid. "Milton also inherited the Ptolemaic cosmology".

${ }^{62}$ Hymn on the Nativity, st. XII.
} 
The music-of-the-spheres idea finds repeated expression. Furthermore, when Milton was tutor to his nephews, 1642-7, he taught them astronomy from John Holyrood's De Sphaera. This man was a thirteenth century scientist, "entirely and especially Ptolemaic". ${ }^{53}$ In a word, Milton had his mind filled with the old natural philosophy when he began "brooding over the subject of his great epic".

The new philosophy, however, was not unknown to him. In 1638-9, he made a journey to Italy where he "saw and conversed with Galileo". ${ }^{54}$ From this interview it may be assumed that he gained a fairly clear idea of the epoch-making work of that scientist. That his mind was interested in scientific research is shown by his Tractate on Education, where he urges a greater study of science. $^{55}$ From 1642 to 1665 , while Paradise Lost lay in abeyance, the new experimental philosophy made great progress in England. Astronomy, as has been shown, was being revolutionized, and men's conceptions of the heavens were rapidly changing. Scientific inquiry had become popular in London; Sorbiere found a public telescope set up in St. James Park..$^{58}$ The time was drawing near for Newton to demonstrate the truth of the Copernican theory and define with accuracy the laws of gravitation at which Hooke and others had broadly hinted.

In the midst of this scientific readjustment Milton came to the writing of Paradise Lost. As might have been anticipated, the whole background of his cosmology is made up of the old science. There are suggestions of the spheres of Dante's world $;^{57}$ there are spirits that walk the earth unseen $;^{58}$ there are planets that are inhabited by the monstrous and abortive births from this world ;0 the stars move in a "mystic dance, and not without song" ";0 the rolling heavens turn on a great axle $;^{61}$ the stars shed their old-time

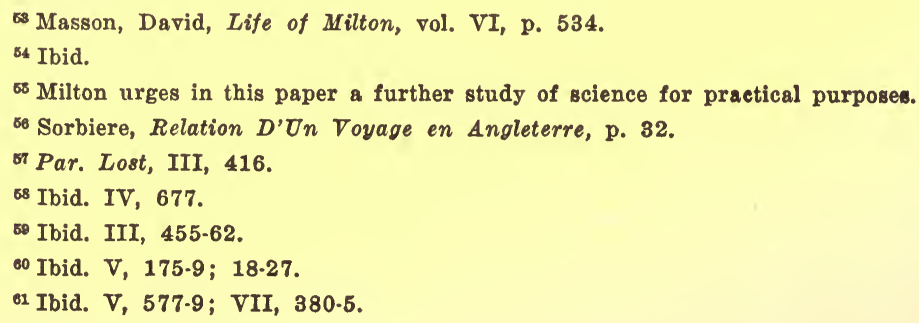


astrological influence $;^{62}$ the alchemists change the baser metals into gold in the regions below ; ${ }^{63}$ and; finally, man stands as the centre of the universe. These details show how Milton employed, apparently without hesitation, the old beliefs, and based his colossal fabric on the old physical conceptions. And so solidly did he build that even in the nineteenth century Huxley found it necessary to attack the science of Milton rather than that of Genesis.

But Milton's mind was not wholly undisturbed by the new ideas. The "optic tube" of Galileo rose persistently in the midst of his imaginings $;^{64}$ the poet seemed troubled by it, if not really fearful lest it should bring his whole house of cards tumbling about his ears. And he was right, too, in his apprehensions, for even as he wrote the scientists were grinding the lenses for a telescope that would enable them to see, beyond the shadow of a doubt, the false basis of his physical theories. But Milton had every reason to want to know the truth; he was purposing to write a poem which he hoped the world would not willingly let perish, and its foundations must be laid as firmly as possible. To Adam, therefore, he gave the inquisitive mind of the new philosopher who would not be satisfied with the old traditions and accepted explanations; to Adam he gave also a glimpse of the new conception, destined to revolutionize theology and philosophy, of man's comparative insignificance in the infinite expanse of the universe. Adam, like John Locke, began to doubt the long-accepted "anthropocentric idea"; "the scenery had become too wide for the drama". ${ }^{65}$

"Reasoning I oft admire", said the inquisitive Adam to Raphael, "how Nature, wise and frugal, could commit such disproportions". .6 The significant word "reasoning", at once put all the old beliefs upon the defensive; nullius in verba can be truly called Adam's motto as well as that of the new philosophers; he, like them, has proposed "to examine all systems, theories, principles, hypotheses". Raphael, at first, answered him evasively that "it makes no

62 Ibid. VIII, 511-3.

63 Ibid. VII, 346-8.

64 Ibid. I, 287-90; V. 261-2; III, 587-90; VIII, 74, 149; "In Paradise Lost there are nine references to Galileo and one to Copernicus".-Woodhull, Marianna, The Epic of Par. Lost, p. 310.

${ }^{65}$ Stephens, Leslie, History of Eng. Thought in 18th Cent., vol. I, p. 81.

6s Par. Lost, VIII, 15-36. 
difference whether the heaven or earth move, and that the Great Architect had not divulged this secret even to the angels" ${ }^{67} \mathrm{He}$ many have left it a mystery for the purpose of leading man on to wild conjecture in order that He might sit in the heavens and laugh at the "centric and eccentric, cycle and epicycle, orb in orb". ${ }^{68}$ Man ought rather to wonder and be content than to pry into these deep secrets. But the new philosopher will not be satisfied with this answer; some definite attitude must be taken towards those new ideas concerning the motion of the earth which were then rife in England. The result of this insistence was a skillful evasion. "Admitting motion in the heavens, not that I so affirm, though so it seem to thee who hast thy dwelling here on earth, it imports thee not. Or what if the sun be centre to the world, what if the light sent through the transpicuous air to the terrestrial moon make earth seem like a star, what if the moon be inhabited, ${ }^{69}$ what if there be other suns with their attendant moons ? ${ }^{70}$ Whether thus these things be, or whether not, whether the sun rise on the earth or the earth on the sun, ${ }^{71}$ solicit not thy thoughts with matters hid; leave them to God, Him serve and fear". ${ }^{2}$

"Be lowly wise,

Think only what concerns thee, and thy being;

Dream not of other worlds, what creatures there

Live, in what state, condition, or degree,

Contented that thus far hath been revealed

Not of earth only, but of highest Heaven." "73

What had been revealed to Adam in direct answer to his inquiry was precisely this,- these things may or may not be so. And this attitude seemed wholly satisfactory to Milton; once past this doubtful ground, he went confidently on, as when earlier he had followed implicitly the Mosaic account. There was apparently considerable relief expressed in that final apostrophe to science, when once he had gone by this lion in the way.-

67 Ibid. VIII, 70-85.

68 Par. Lost, VIII, 115-9.

${ }^{69}$ Ibid. VIII, 140-5.

${ }^{70}$ Ibid. VIII, 148-52.

71 Ibid. VIII, 159-62.

72 Ibid. VIII, 167-8.

73 Ibid. VIII, 173-8. 
"Mother of Science! Now I feel thy power

Within me clear; not only to discern

Things in their causes, but to trace the ways

Of highest agents, deemed however wise." ${ }^{74}$

From the background of this vast structure stands forth the simple query of the new philosophy,-How can these things be? Milton himself knew not what to answer. The Miltonic universe trembled to its foundation before the "wary and circumspect" attitude of the new scientists. The poet dared not scorn the new theories, nor could he wholly ignore them; and yet, he was afraid to accept lest he should be too hasty. "Raphael, while not denying the true astronomy, had not suffered Adam to deny the false". ${ }^{75}$ Such an attitude of doubt must find expression in equivocation, and equivocation is only a skillful means of evading an adjustment to new ideas. As a consequence, Paradise Lost represents the great scientific evasion of this period of transition.

Dryden, who was far more a poet of his period than Milton, was another literary member of the Royal Society. Although there is no record of his attending any of the meetings, he was certainly acquainted with some of the investigators and had a good opportunity to know the character of their work. But his real attitude toward the new philosophy is hard to define, for there is a heterogeneous mixture of what is old and what is new in his verse. The Annus Mirabilis, for example, has a striking figure based on the circulation of the blood, ${ }^{76}$ and references to the recent theories on the formation of ores underground ${ }^{77}$ and the causes of meteors. ${ }^{78}$ But woven into the very texture of the poem is the imagery of astrology. ${ }^{79}$ The new material is, however, directly out of the discussion of scientific circles; the poet has followed thus far the injunction of Bishop Sprat,- - to use experiments for poetic imagery.

One passage must be noted in detail, a prophetic address to the Royal Society, which shows some appreciation of the poetic possibilities in the new scientific ideas.-

74 Par. Lost, IX, 679-82.

76 Elton, Oliver, The Augustan Ages, p. 211.

${ }^{76}$ Annus Mirabilis, 5-6.

77 Ibid. 529.

${ }^{78}$ Ibid. 559.

${ }^{70}$ Ibid. 553-6. 
"Then we upon our globe's last verge shall go, And view the Ocean leaning on the sky;

From thence our rolling neighbors we shall know, And on the lunar world securely pry.

Till I foretell from your auspicious care, Who great in search of God and Nature grow;

Who best your wise Creator's praise declare, Since best to praise his works is best to know.

O truly royal! Who behold the law And rule of things in your Maker's mind;

And thence, like limbecs, rich ideas draw, To fit the levelled use of human-kind." 80

In the Epistle to Dr. Charleton there is high praise expressed for the leading scientists of the century, "the assertors of free reason's Claim".

"The world to Bacon does not only owe

Its present knowledge, but its future too.

Gilbert shall live, till loadstones cease to draw, And noble Boyle, not less in nature seen,

The circling streams, once thought but pools

From dark oblivion Harvey's name shall save."

There is, besides, such a recent scientific experiment as the transfusion of blood poetized by Dryden in his lines to Mrs. Anne Killigrew,- "Thy father was transfused into thy blood". But he had already transferred her soul to some neighboring star, which "moved with heaven's majestic pace"; the milder planets of the old astrology had combined to shine on her auspicious horoscope; and the spheres for her were musical, as Ptolemy had said. ${ }^{82}$ Elsewhere also, as in the poem Upon the Death of Lord Hastings, and in the lines To Sir Robert Howard, Dryden knows only the "dancing crystal spheres" and "the atoms casually together hurled". Even when polishing Milton's Paradise Lost into heroic couplets in The

80 Ibid. 653.

81 Epistle to Dr. Charleton.

${ }^{82}$ Lines to Mrs. Anne Killigrew, 41-2, 489-90. 
State of Innocence, and the Fall of Man, the earth is "self-centred and unmoved", while the "moving sun" brings the new day. ${ }^{83}$

From all of which it follows that Dryden was not deeply impressed with the new philosophy. It seems never to have occurred to him that it was a serious matter to know the truth about nature, or at least to be consistent about its representation. He never learned 'to read in the great book of nature, to walk in its garden and taste its plenty'. With his splendid opportunity to associate with the best scientific minds of his time, he cast them all aside with a word of compliment, and sought Will's Coffee House for political gossip. He was too much engrossed with the affairs of men, and his genius was too "narrow" for him to appreciate these new ideas. His general attitude is, therefore, not so much one of "doubting between belief and grimace", as of indifference and inappreciation.

To one "who examines historically the movements of imagination" this entire group of transition poets will illustrate the "strange contradictions of human nature". Living under the power of the new forces they wrote for the most part out of an earlier experience; they still dwelt in imagination among the idols which were fast being cast down by the new philosophy. And they were neither consistently faithful to the old nor courageously true to the new. In them imagination had not yet overtaken reason, and scientific facts came to them unwarmed with poetic emotion. 'The bare framework of formulae had not yet gathered round it the necessary associations' for a direct expression of their feelings in terms of the new science. ${ }^{84}$ Milton alone, even in his blindness and equivocation, found the broadened horizon of the new astronomy. For the rest, they were either indifferent, uninspired or inconsistent.

Some mention should be made of the attitude of Thomas Hobbes before passing from the poets to the sharp critical struggles which the new philosophy had with "the traditions of ancient faith". He should have been a good friend and well-wisher of the new science for this polemical philosopher, trained in the new method nnder Lord Bacon, was imbued with its spirit. But he failed to

The State of Innocence, and the Fall of Man, Act II, sc. 1.

stephen\$, Leslie, History of Eng. Thought, vol. I, p. 15. 
keep step with the progress of the men at Gresham College. In consequence, he put up a man of straw, "vain Philosophy," to serve as his antagonist. This "vain Philosophy" he confused with the Aristotelianism of his own university days. "Since the Authority of Aristotle is only current there," he says of Oxford in The Leviathan, "that study is not properly Philosophy (the Natare whereof dependeth not on Authors) but Aristotelity".85 But he had never read those valiant words of a new philosopher,-- "No principles are received as cogent, no principles allowed as current, but what in themselves are intelligible". He had only recently come under the fascination of mathematics. "Hobbes never opened Euclid until he was past forty. When he was at Oxford, Geometry made no part of a student's training". ${ }^{86}$ Remembering the universities as they were in his youth, and unaware that Oxford had outstripped him in scientific progress, he launched his criticism against a curriculum that had no mathematics in it, against an attitude that regarded this study as an "Art Diabolicall". But his criticism was late in coming; as for mathematics, Wallis, upon whom Hobbes later concentrated his hostility, was a far superior mathematician to that philosopher himself. When Wallis showed him his mistake in this matter, Hobbes continued his opposition through wounded pride. Wallis had also shown the absurdity of Hobbes's attempts to square the circle and to find a quadrature for the cube. ${ }^{87}$ The criticisms that Hobbes had to make were, therefore, due at first to ignorance and at last found support in perversity.

The task of writing the historical defence of the new science fell upon Bishop Sprat. The result of his efforts to perform this task was his History of the Royal Society (1667). He divided the book into three parts; the first giving only the origin and development of the Society up to the date of writing, the second devoted to the achievements of the virtuosi, and the third serving as a defense of the new philosophy. ${ }^{88}$ In this defense the author discussed the various benefits to be derived from the new study. The last of these benefits from experiments "is that their dis-

8 Leviathan, p. 496.

80 Traill, H. D., Social England, vol. VI, p. 79.

87 Phil. Trans. Mar. 16, 1668; Apr. 13, 1668; Feb. 15, 1669; June 21, 1669; Jan. 17, 1670.

History of $R$. S., pp. 323, 413, 417. 
coveries will be very serviceable to the Wits and Writers of this, and all future Ages .... . There is in Nature such an inexhaustible treasure of Fancy, and Imagination, which will be revealed proportionately to the increase of their Knowledge". 89

The Bishop is particularly anxious to secure the good will of the "Wits and Railleurs", for these, he thinks, can do more injury to the new cause than all the other detractors. His plea runs thus: 'In the material of experiments and consequent discoveries lies 'the most fertile subject of Fancy'. This new material is sorely needed, because the old virtues and qualities of things 'have long borne the burden alone, and have bin vex'd by the imagination of the Poets'. The imagery of the new science 'will make the most vigorous impression on Men's Fancies, because they do even touch their Eyes, and are nearest to their Nature. Of these the Variety will be infinite, for the particulars are so, from whence they may be deduced. They may be always new and unsullied, seeing there is such a vast number of Natural and Mechanical things, not yet fully known or improv'd, and by consequence not yet sufficiently apply'd'. ${ }^{90}$ Furthermore, he declares that "the English Tongue, as it contains a greater stock of Natural and Mechanical Discoveries, so it is also more enrich'd with beautiful Conceptions, and inimitable Similitudes gather'd from the Arts of Man's hands, and the works of Nature, than ever any Language could produce". ${ }^{91}$ And, finally, as an example of what the new scientific study of nature will do for the style of a literary man, Sprat cites Sir Francis Bacon. "The use of Experiments to this purpose is evident by the wonderful advantage that my Lord Bacon received from them. This excellent Writer was abundantly recompensed for his noble Labours in that Philosophy, by a vast treasure of admirable Imaginations which it afforded him, wherewith to express and adorn his thoughts about other matters". ${ }^{92}$

This appeal is strong and sensible, and later writers have dem-

89 Ibid. p. 417.

${ }^{00}$ History of the Royal Society, p. 416.

91 Ibid. p. 417.

92 Ibid. p. 416. 
onstrated the truth of his position. But Sprat himself, as a writer of verse, failed to bring his precepts into practice. His principles condemn his own poetry. The only reference to the material of the new science are found in his poems, To the Lord. Protector, and To Abraham Cowley. These lines, even, are filled with the imagery of the old Ptolemaic cosmology, ${ }^{93}$ the imagery of astrology, and medical superstitions..$^{94}$ The music of the spheres sounds on through his verse, in spite of Copernicus and Galileo. ${ }^{95}$ He had written against the belief in witches and fairies,- "the course of Things goes quietly along, in its own true channel of Natural Causes and Effects, for this we are beholden to Experiments". ${ }^{96}$ And yet, as a poet, he made use of sympathetic powder ${ }^{97}$ and judicial astrology. ${ }^{98}$ In brief, there is in Sprat's verse no use of the new material of scientific experiments and discoveries. When he wrote theory, he was sane and intelligible and progressive; whén he turned poet, he forgot his own doctrine. His theory was sound, but he brought nothing to practice.

In Sprat's History of the Royal Society is to be found the first evidence of the rising tide of opposition against which the new philosophy was destined to struggle for forty years. The new science fosters scepticism and nurtures atheism, said the churchmen; it is not in harmony with Plato and Aristotle, said the philosophers; it is a foolish humor, said the wits. To each of these Sprat makes reply. The last objection only has been discussed here, because the others appear later on. In his effort to propitiate the "Wits and Railleurs", Sprat has presented a remarkable example of how advanced a man may be in theory without bringing it to practice. In literary theory he anticipated the late eighteenth century poets; in poetic practice he belonged to the second quarter of the seventeenth century.

While it is true, through these years, that "philosophy was preoccupied with the problem of differentiation of science from

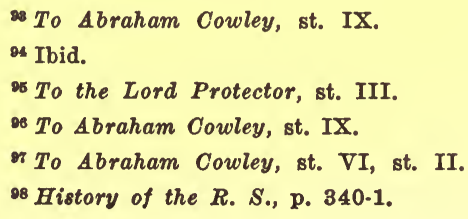


theology", 99 yet it was inevitable that the search for natural causes should arouse controversy among the clergy. One man of this period stood as the central figure in such an extended controversy. It partook of the character of theology, ${ }^{100}$ of philosophy, and of science, but belongs here because it found literary expression in the work of Joseph Glanvil, who has been more nearly forgotten than he deserves. As the result of an essay-Scepsis Scientifica, 1665-which is a fairly clear exposition of the "wary and circumspect" attitude of the new philosophers, he was elected Fellow of the Royal Society. "The Lord Brereton presented a book written by Joseph Glanvil, M. A., and entitled Scepsis Scientifica, dedicated to the Royal Society, the dedication of which was read. Mr. Glanvil was proposed as a candidate by Lord Brereton". ${ }^{101}$ And thus another man with literary bent and with a keen, imaginative mind was brought into direct contact with the new ideas. In his case it proved to be a stimulating, if not inspiring, experience, and quickened many a page of his philosophy. He seemed to feel that the mantle of Lord Verulam had fallen upon him and that he was called to complete the fragmentary New Atlantis. ${ }^{102} \mathrm{He}$ became, likewise, a staunch defender of the Royal Society against the venomous attacks of Dr. Stubbe, the hireling of Robert Grosse, sometime Oxford Fellow and upholder of Aristotelianism. ${ }^{103}$

In all of this Glanvil was a thoroughgoing new philosopher; but it is in the controversy concerning witcheraft that he represents the conflict between the old and the new ideas. He believed in witcheraft and undertook to explain it on a scientific basis. In this struggle he joined forces with Henry More, the Cambridge Platonist. As Mr. Greenslet says,--"In matters of witcheraft Glanvil and More hunted in couples". ${ }^{104}$ The new science had put the long-accepted belief on the defensive, and Glanvil's problem

${ }^{20}$ Seth, James, English Philosophers, p. 17.

100 Birch, Thomas, History of the Royal Society, p. 500.

101 There is an alluring field of investigation in the contribution of the new science to rational theology and to 18th century philosophy. Cf. Seth, English Philosophers, Stephen\&, History of English Thought, Remusat, Histoire de la Philosophie en Angleterre, Tulloch, Rational Theology, etc.

102 Essay VII, Anti-fanatical Religion and Free Philosophy.

108 Greenslet, F., Joseph Glanvil, p. 778.

104 Ibid. p. 154. 
was to reconcile that belief with the new demand for a reasonable and natural explanation, and at the same time keep in harmony with orthodox theology. Writing in the language of the new philosophy and especially of Descartes, he declared that "the best way to attain true knowledge is to suspend the giving our confirmed assent to those Receptions, till we have looked them over by an impartial inquiry; to reckon of them all as false, or uncertain, till we have examined them by a free and unpossest Reason; and to admit nothing but what we see clearly and distinctly perceive."105 This is in perfect accord with the "free philosophy" of the time; a "free and unpossest Reason" in search of truth in natural phenomena was the fundamental principle of the new science. This principle guided Glanvil confidently on to a certain point, where it met its old enemies, accepted beliefs and inherited prejudices. Further than this Glanvil's mind could not go. That point marked the dividing line between the free play of "unpossest Reason" and theological faith. "Now after all this, it will be requisite for me to add, that I intend not these Remarques in favor of any Conceits in Theology, to gain Credit to such by disparaging Antiquity; No, here the old Paths are undoubtedly best, quod verum id prius: And I put as much difference between the pretended New Lights, and old Truths, as I do between the Sun and an Evanid Meteor; Though I confess, in Philosophy I am a seeker"'. ${ }^{108}$ But a seeker who blind-folds himself before he begins an investigation of certain problems will surely break his shins upon some sharp-cornered inconsistency. And so it was with Glanvil.

In Essay VI, Upon Witches and Apparitions, he prefaced the whole discussion by a statement of his attitude that virtually begged the question, and was certainly inconsistent with his "vanity of dogmatizing". "If anything were to be much admired in an Age of Wonders, not only of Nature, (which is a constant Prodigy) but of men and manners; it would be to me matter of astonishment, that men, otherwise witty and ingenious, are fallen into the Conceit that there's no such thing as a Witch or Apparition, but that these are creatures of Melancholy and Superstition, fostered by

108 Essay I, p. 22.

106 Essay I, p. 28. 
Ignorance and Design". ${ }^{107}$ Once having espoused the belief it behooved him to establish it by scientific argument and by facts. This he endeavored to do by "evidence of authority and sense". The essay, which was later expanded into the book entitled Sadducismus Triumphatus (1681), contains a number of stories of witchcraft, the most famous of which is The Demon of Tedworth. ${ }^{108}$

There is no need to review the arguments here. The important point is to note the rise of the controversy, this final struggle between the accepted belief and the scepticism of the new science. This literary virtuoso employed his best talent in the defence of the old. He was a gifted man, who, with all his acumen and often far-sighted imagination, yet yielded obeisance to this figment of melancholy and superstition. Among the numerous essays against the belief, only two will be mentioned here. One was by John Webster,-Displaying of Supposed Witchcraft, 1676,-which called forth an answer by Glanvil and Henry More (Sadducismus Triumphatus). Webster declared that all witcheraft was founded on imagination, ${ }^{109}$ - a view presented before the Royal Society. ${ }^{110}$ The detailed answer was written by Glanvil, but he died before its publication. The Controversy did not cease, however, with Glanvil's death, (1680), for neither side would yield. "At least thirteen books in defence of the belief were published between 1680 and 1718, but they were powerless to check the sceptical tendency. Among these writers Glanvil was regarded as the great authority of their subject"'.111 Finally, in 1718, Dr. Francis Hutchinson wrote An Historical Essay Concerning Witchcraft, which silenced, if it did not convince, the defenders of the belief. It was his judgment,-it was undoubtedly sound-, that the Royal Society was the most potent cause of the decline of the superstition. ${ }^{112}$ The effect of this essay is illustrated in the different attitudes in Addison's De Coverley Papers (1710) and The Drummer (1715) and of De Foe's Satiric History of the Devil (1726).

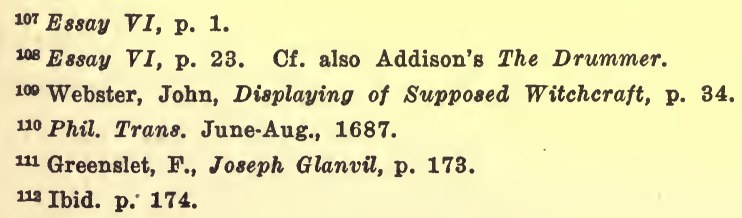


But here our interest ends, for, though private belief may long have continued, ${ }^{113}$ there was a virtual victory for scientific scepticism.

This controversy shows the limitations of Glanvil's mind, but within his field of appreciation he had remarkable power. Far beyond any of the contemporary poets is Glanvil's use of the inventions and discoveries of the new science for imaginative material. "The world of God, no doubt, is another thing, than the world of sense is; and we can judge but little of its amplitude and glory by the imperfect idea we have of it. From this narrowness of our senses it is, that we have been so long ignorant of a world of Animals that are with us, and about us, which now at last the Glasses, that in part cure this Imperfection have discovered; and no doubt, there is yet a great variety of living Creatures that our best Instruments are too gross to disclose; There is prodigious fineness and subtilty in the Works of Nature; And sometimes I fear that we scarce yet see anything as it is". ${ }^{114}$ And the "seeker in Philosophy" spoke forth with valiant courage in defiance of ancient authority in these words; " 'Twas never a Heresie to outlimn Apelles; or to out-work the Obelisks; Galileo without Crime, out-saw all Antiquity, and was not afraid to believe his Eyes, in reverence to Aristotle and Ptolemy. 'Tis no disparagement to those famous Optick Glasses that the Ancients never us'd them, nor are we shy of their Information, because they were hid from the Ages. We believe the polar virtues of the loadstone without certificate from the days of old, and do not confine ourselves to the sole conduct of the stars, for fear of being wiser than our Fathers". ${ }^{115}$

There is no well-constructed system in Glanvil's scientific ideas. Nor is there reason for wonder at this, even when his clear mind and sane judgment are known. He lived in a period of transition when an old system was crumbling and a new one was just floating into definition. Glanvil is at a stand about the movement of the earth, for the great Newton had not yet spoken; but his mind was open to conviction and ready to receive the demonstration of new ideas. When a man admits a grave doubt he cannot

\footnotetext{
113 John Wesley and Samuel Johnson are said to have believed in witches.

114 Es8ay I, p. 17.

116 Essay I, p. 26.
} 
construct a coherent system. "The gradual ebbing of an ancient faith leaves a painful discord between the imagination and the reason"..116 Glanvil should not, therefore, be discredited because of his inability to be consistent. His great literary achievement was that in the midst of this "imperfect fusion of experiment and dreaming" his mind could give life to the dry bones of scientific facts and formulae. This man had the prophetic vision inspired by the possibilities in science. "I dare not therefore mention our greatest hopes; but this I will adventure, That 'tis not unlikely but Posterity may by those Tubes, when they are brought to higher degrees of perfection, find a sure way to determine those mighty questions: Whether the Earth moves? or, the Planets are inhabited? And who knows which way Conclusions may fall?"'117 The glimpse he had caught of the "constant Prodigy" of nature had forced upon him the realization of the narrow bounds of man's real knowledge. "And when I look back upon the Main Subject of these papers, it appears so vast to my Thoughts, that me-thinks I have drawn but a cockle-shell of water from the ocean; Whatever I look upon, within the Amplitude of Heaven and Earth, is evidence of Human Ignorance: For all things are a great Darkness to us, and we are to ourselves; the plainest things are obscure, as the most confessedly mysterious; and the plants we tread on are as much above us as the Stars and Heavens". ${ }^{118}$ If this man had been a poet, he would have entered into the great inheritance of new material promised by Bishop Sprat. As it was, Glanvil used the new imagery much after the manner of Lord Bacon, and enriched his pages with new and vivid similitudes.

A second controversy, that grew out of the breaking up of the old system and that found literary expression, centres in the Sacred Theory of Thomas Burnet. It was a corollary to the reconstruction of natural history that an inquiry should be made into the harmony between the accepted notion of the beginning of the world and the experiences through which it passed, and the newfound scientific principles. A man of literary genius was required to give expression to the inquiry. Thomas Burnet was called

116 Stephens, Leslie, History of English Thought, vol. I, p. 15.

${ }^{117}$ Essay I, p. 20.

118 Essay III, p. 24. 
to this service. The first part of the Sacred Theory appeared in a Latin quarto, 1680, and was commended by Charles II. In 1684 an English folio was published dedicated to the King. Nine years later the second part came out; and three years afterward his Archaelogiae Philosophiae, the offspring of the former study, satirized the biblical account of the fall of man.

Then the battle was on. No sooner had the Sacred Theory been discovered than it was attacked. Erasmus Warren, Rector of Worlington in Suffolk, wrote the first eriticism. Burnet answered; Warren fell upon the theory again, adding a personal attack; Burnet retorted in kind. In $1698 \mathrm{Dr}$. Keill wrote an essay against the Sacred Theory, to which Burnet replied in A Review, etc. At almost the same time Whiston's New Theory of the Earth was published (1697). Then Blount praised Burnet's work in his Oracles of Reason. But the Bishop thought he had vindicated his theory and was afterwards silent. Dr. Keill, however, wrote a second criticism in 1734, which practically refuted the entire hypothesis upon which Burnet had built his wonderful fabrication. These "flytings" are all far inferior to the Sacred Theory itself, with which this discussion is to deal. It may be noted in passing what the judgment of the phlegmatic scientists was upon this book. Dr. Keill claimed "that it was his (Burnet's) unhappiness to begin at first with the Cartesian Philosophy, and not having a sufficient Stock of Mathematical and Mechanical Principles to examine rightly, he rashly believed it, and thought that there was but little skill required in those Sciences to become a Philosopher; and therefore, in Imitation of Descartes, he could undertake to show how the World was made, a task too great even for a Mathematician." 119 When the author made inquiry of Dr. Flamstead as to his opinion of the Sacred Theory that scientist's laconic reply was,- "There goes more to the making of the World than a fine turned Period". "The whole Theory", he said, could be overthrown in "one sheet of paper". ${ }^{120}$ The written page does not record the author's answer.

Burnet, however, was a writer of splendid imagination and possessed of a power of vivid description. He was also a man of

110 Sacred Theory, vol. I, Preface, p. XXXI.

120 Sacred Theory, vol. I, Preface, p. XXXI. 
considerable classical learning, for he could discuss with intelligence various possible renderings of Greek and Hebrew passages in the Old Testament. His scientific knowledge was just sufficient to make him rush in where Milton feared to tread. From Descartes he got the notion of the "liquid heavens where the planets were carried about the sun with the same common stream", 121 of "the true Principles that govern Nature, which are Geometrical and Mechanical", ${ }^{122}$ of the various spheres of homogeneous matter, ${ }^{123}$ of matter and motion, ${ }^{124}$ and of "plain and perspicuous style". ${ }^{125}$ He did not try to conceal his borrowings; "an eminent Philosopher of this Age, Monsieur Des Cartes, hath made use of the like Hypothesis". ${ }^{126}$ He had followed the most recent astronomical observations ; ${ }^{127}$ he knew the latest miscroscopical investigations upon the circulation of the blood $;{ }^{128}$ he was acquainted with the recent experiments with steam, and professed to have a theory of his own regarding it $;^{129}$ he had attained to the new conception of the infinite dimensions of the universe and the comparative littleness of man; he knew the latest geological observations on the strata of rocks. ${ }^{130} \mathrm{He}$ had cast aside the old belief respecting the stars,- "It is full Time now to sweep away these cobwebs of Superstitions, these Relics of Paganism. I do not see how we are any more concerned in the Postures of the Planets than in the Postures of the Clouds". ${ }^{131}$

The critics of the Sacred Theory doubted whether Burnet himself really believed his own hypothesis. In answer to this allegation the Bishop firmly asserted his unswerving allegiance to the cause. "I must profess my Assent to the Substance of that Theory; and am the more confirmed in it by the Weakness and In-

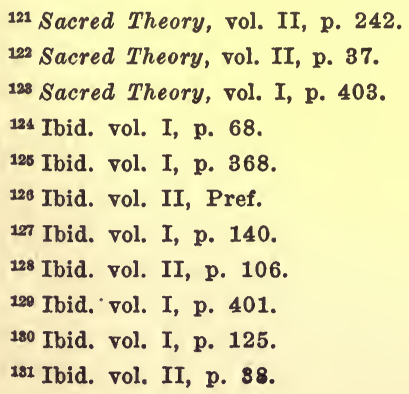


efficiency of these Exceptions". ${ }^{132}$ But the question of its validity has long since passed and its influence has been swallowed up in that of Paradise Lost, against which Huxley found it necessary to direct his attack instead of against the Mosaic account. Here it needs only to be pointed out that another literary mind has been brought into close contact with these new scientific ideas; here is another genius who has devoted his energy to a losing cause, and his attempts to adjust the accepted beliefs to the new knowledge, to harmonize the "painful discord" between imagination and reason, have found literary expression.

Burnet, like Glanvil, found new possibilities for literary expression in the new learning. Frequently he was as sublime as Milton himself, but his imagery belonged to this earth; he dealt with the "sublunary world" which he saw. In his hypothesis the earth was assumed to have arisen out of "original chaos", so that he could keep himself firmly planted on the solid ground. He attempted to give a strictly scientific account, "always guided by reason". ${ }^{133}$ But there were certain points where he could not restrain his aroused imagination. In the description of the deluge there is such a passage; "Thus the Flood came to its height; and 'tis not easy to represent to ourselves this strange Scene of Things, when the Deluge was in its Fury and Extremity; when the Earth was broken and swallowed in the Abyss, whose raging Waters rose higher than the Mountains, and fill'd the Air with broken Waves. with an Unusual Mist, and with thick Darkness, so as Nature seem'd to be in a second Chaos; and upon this Chaos did ride the distressed Ark, that bore the small remains of Mankind. No sea was ever so tumultuous as this. Nor is there anything in present Nature to be compared with the Disorder of these Waters; All the Poetry, and all the Hyperboles that are used in the Description of storms and raging Seas, were literally true in this, if not beneath it." "134

To him "the greatest Objects of Nature were the most pleasing to behold". Next to the great concave of the heavens, "there is nothing that I look upon with more Pleasure than the wide Sea

132 Sacred Theory, vol. II, p. 440.

139 Ibid. vol. I, p. 122.

194 Sacred Theory, vol. I, p. 122. 
and the Mountains of the Earth. There is something august and stately in the Air of those things, that inspires the mind with great thoughts and Passions". ${ }^{135}$ "See", he exclaims, "How scornfully they look down upon us, and bid defiance to all the Elements; they have borne the Thunder and Lightning of Heaven, and all the Artillery of the Skies, for innumerable Ages; and do not fear the crackling of thorns and shrubs that burn at their Feet". ${ }^{136}$ The writer of this passage is anticipating the poets of the late Eighteenth century in his appreciation of the grand objects of nature. And it was his interest in scientific observation that gave him sufficient familiarity to interpret their spirit. For Burnet the sky, the sea and the mountains were not the mere tinsel of poetic adornment, but objects of reality and wonder and inspiration. Here is a truly literary interpretation of new scientific knowledge: "The Continents were made of those three or four primary masses into which the falling orb of the Earth was divided; but the Islands were made of the Fractures of these, and broken off by the Fall, from the Skirts and Extremities of the Continents". ${ }^{137}$ The sea, too, had its inspiration for him. "I have observed in many places a Ridge of Mountains some Distance from the Sea, and a Plain from their Roots to the Shore; which Plain no doubt was formerly covered by the Sea, bounded against those Hills as its first and natural Ramparts, or as the Ledge or Lips of its Vessel". ${ }^{138}$ This is a successful attempt to translate into intelligible and striking imagery his scientific idea. One may smile at his antiquated hypothesis, - that the Lord threw up the mountains in a haphazard manner for men to wonder at, that the stars in the sky were more orderly before the fall of man, that the earth before the flood was as smooth as a table,- - but one must admire the vigor of his imagination and this remarkably successful effort to give literary life to a scientific discussion. One more illustration will suffice: "If we should suppose the Ocean dry, and that we looked down from the Top of some high Cloud upon the empty Shell, how horribly and barbarously would it look? and with what

\footnotetext{
195 Ibid. vol. I, p. 105.

186 Ibid. vol. I, p. 172.

197 Ibid. vol. I, p. 170.

138 Sacred Theory, vol. I, p. 125.
} 
Amazement should we see it under us like an open Hell, or a wide bottomless Pit? So deep, and hollow, and vast; so broken, and confused, so every way deformed and monstrous. This would effectually waken our imagination, and make us enquire how such a thing came in Nature; from what Causes, by what Force or Engines could the Earth be torn in this prodigious Manner? Did they dig the Sea with Spades and carry out the Molds in Handbaskets?" 139

Burnet has accomplished these things in his futile attempt to found a new system on the fragments of the old: I. He has shown that new scientific facts can be so infused with imagination as to become poetic. 2. He has secured the effects of Miltonic and Aeschylean imagery out of the solid material of this world. 3. He has been led through scientific interest to observe with clearness and enthusiasm the objects of nature.

The final assault upon classical authority found its best literary expression in Swift's Tale of a Tub and Battle of the Books. Here again the quarrel reached far beyond the new science. In so far, however, as the ancient scientists are defended against the moderns we are concerned. How Wotton persuaded Dr. Bentley to print his Essay on Phalaris as an appendix to his own Reflections Upon Ancient and Modern Learning is sufficiently familiar. ${ }^{140}$ It was this that precipitated the fight for supremacy between the old classical literature and the modern. But another quarrel that began in France between Fontonelle and Perrault on the one hand and Boileau on the other ${ }^{141}$ was caught up in England by Sir William Temple, who published in 1690, among other miscellanies, $\mathbf{A} n$ Essay Upon Ancient and Modern Learning. One part of this Essay was aimed directly against the claims of the new philosophers for the great progress of modern science both in discoveries and inventions, and particularly against their bold defiance of ancient authority. To this Essay William Wotton made reply,

130 Ibid. vol. I, p. 163-4.

140 Dyce, Alex., Works of Richard Bentley, Preface.

141 See Fontonelle and Perrault, Biographie universelle. Here belongs that remarkable man, Pierre Bayle, with his Letter (1682) and his "Learned notes" in the Dictionary (1697). The Letter begins with an attack on Astrology, but quickly passes over into Theology; the notes are a "scientific scrutiny" of history and classical lore.-Elton, Oliver, The Augustan Ages, p. 24. 
1697, in his Reflections, in defense of the Royal Society and its work. Temple answered at once with Some Thoughts Upon Ancient and Modern Learning. Then Dean Swift's satiric masterpieces laughed the quarrel away.

Sir William Temple's position can be stated briefly ; "Tis very true and just, all that is said of the mighty Progress that learning and Knowledge have made in these Western Parts of Europe, within these hundred and fifty years". ${ }^{142}$ But, "may there not have been, in Greece and Italy of old, such Prodigies of Invention and Learning in Philosophy, Mathematicks, Physicks, Oratory, Poetry, that none has ever since. approached them?"143 When he had surveyed the actual achievements of the modern scientists, he found the sum total to be nothing great. "There is nothing new in astronomy, to vie with the ancients, unless it be the Copernican System; nor in Physick, unless Harvey's Circulation of the Blood. But whether either of these be modern Discoveries, or derived from old Fountains, is disputed; nay it is so too, whether they are true or not; for though Reason may seem to favour them more than the contrary Opinions, yet sense can hardly allow them; and to satisfie Mankind, both these must concur. But if they are true, yet these two great Discoveries have made no change in the Conclusions of Astronomy, nor in the Practice of Physick, and so have been of little Use to the World, though perhaps of much Honour to the Authors". ${ }^{144}$ "The greatest of modern Inventions seem to be the Load-Stone and Gunpowder". ${ }^{145}$ The Society at Gresham College had been led into all sorts of vagaries and wild speculations,-“"wondrous Pretensions and Visions of Men". These were;- "The Universal language, the Philosopher's Stone, the Transfusion of Blood, the universal medicine, the art of flying, double-bottomed ships, the virtues of 'that Noble and Necessary Juice called Spittle', the discoveries of new worlds in the planets, ${ }^{146}$ the cause of thunder and lightning, the motion of the sun and earth".147 After this scathing arraignment he closed with the

\footnotetext{
${ }^{142}$ Essay upon Ancient and Modern Learning, Miscel., Pt. II, p. 36.

143 Ibid. p. 33.

144 Esay Upon Ancient and Modern Learning, Miscel. II, p. 42-3.

145 Some Thoughts, pt. III, p. 255.

148 Ibid. pt. III, p. 281-2.

${ }^{147}$ Essay Upon Ancient and Modern Learning, pt. II, p. 52-3.
} 
query which the new philosophers heard many times; "What has been produced for the Use, Benefit, or Pleasure of Mankind, by all the airy Speculations?" "148

The whole discussion shows, on the part of the writer, merely a superficial knowledge of the scientific activities of the day. Newton's Discoveries had already been published, yet the new worlds of the telescope and the microscope were veiled to Temple. Besides, while all but two of the vagaries he mentioned-the Philosopher's Stone and the Universal Medicine-had been discussed by the Royal Society, they were treated merely as speculations until demonstration was possible. Temple showed no appreciation of the famous group of men who were doing such important things, even while he wrote. All in all his discussion is unfair, prejudiced and superficial.

William Wotton, a Fellow of the Royal Society, took up its defense in a vigorous reply to Temple. He explained the aims and methods of the scientists, and gave an account of the discoveries and the inventions they had made. To him the future was bright for scientific progress, because "the Royal Society has weathered the rude Attacks of such sort of Adversaries as Stubbe, who endeavored to have it thought, That studying of Natural Philosophy and Mathematicks, was a ready Method to introduce Scepticism at least, if not Atheism, into the World; Yet the sly Insinuations of the Men of Wit, that no great Things have ever, or are ever like to be performed by the Men of Gresham, and that every Man whom they call a Virtuoso, must needs be Sir Nicholas Gimerack ; ${ }^{149}$ together with the public ridiculing of all those who spend their Time and Fortune in seeking after what some call useless Natural Rarities". ${ }^{150}$ As to the men themselves, he thinks "those excellent Men do highly deserve Commendation for those seemingly useles: Labours, and the more since they run the hazard of being laughed at by Men of Wit and Satyr, who always have their End, if they make their Readers sport, whether the thing which they expose, deserves to be ridiculed or not". ${ }^{151}$

148 Some Thoughts, pt. III, p. 281.

149 Shadwell's The Virtuoso.

150 Wotton's Reflections, p. 419.

261 Wotton's Reflections, p. 274-5. 
It was at this juncture that Swift came to aid his friend, Temple, with his satire in the Tale of a Tub, and the Battle of the Books. Once again scientific learning has only a small part in the quarrel. To Swift it was a personal matter, for he did not show himself really interested in the struggle to maintain classical authority. His actual position, as nearly as it can be ascertained, is summed up in this sentence from the essay, The Mechanical Operations of the Spirit: "It is hard to assign one art or science which has not annexed to it some fanatic branch; such are, the philosopher's stone, the grand elixir, the planetary world, the squaring of the circle".152 This is good sense, for these things were follies even at that time and deserved censure. The Tale of the Tub ridiculed Wotton as the defender of these absurd claims. "The whole school of Greshamites are too wild in their claims", says Swift, "the whole realm of human knowledge is too broad for one generation to conquer. Besides, the philosophers are working at foolish things." The new discoveries which Swift promised his readers to discuss are these: "My new help for smatterers or the art of being deeplearned and shallow read. A curious invention about mouse-traps. A universal rule of reason, or every man his own carver; together with a most useful engine for catching owls. All which the judicious readers will find largely treated on in the several parts of this discussion." "153 The best word that he had for Descartes was that he had been chosen as chief "in the academy of modern Bedlam". He declared Descartes's ambitions to be that he "reckoned to see before he died, the sentiments of all philosophers, like so many lesser stars in his romantic system, wrapped and drawn within his own vortex". ${ }^{154}$ But this is not a worthy criticism of that philosopher's theory, nor does it show any clear understanding of it.

In the Battle of the Books the greatest scene is a description of the battle itself. Here the scientists take their places in the battle line. "There came the bowmen (philosophers) under their valient leaders, Descartes, Gassendi, and Hobbs; whose strength was such that they could shoot their arrows beyond the atmosphere, p. 172).

${ }^{152}$ Swift, Jonathan, The Mechanical Operations of the Spirit, (Everyman's Edition,

158 The Tale of the Tub, (Everyman's Edition, p. 108).

154 Ibid. p. 107. Repeated in the Battle of the Books, p. 160. 
never to fall down again, but turn like that of Evander, into meteors; or, like the cannon ball, into stars." 155 Paracelsus led the "stink-pot flingers", Harvey the dragoons, Wilkins the "enginers". The victory went in this case to the ancients. "Homer slew Wesley, and then seized Perrault and hurled him at Fontonelle, killing both." "156 "Aristotle let fly an arrow at Bacon, and missing him, pierced the eye of Descartes." "157 The whole battle, however, closed in a draw, but the advantage had all been on the side of Temple and the Ancients.

This heroic burlesque shows what the layman might be expected to know of the activities in science. Swift, in his early years, had expressed a great admiration for scientific research. It would seem that this interest might have led him to considerable knowledge of the new experiments. In these two satires, however, where he is a special pleader, only the most obvious things, the most sensational things are mentioned. He made the most of the satiric possibilities in the sensational claims of the new philosophers. But of the real workers, of Newton, Boyle, Hooke, Halley, Hans Sloane, Ray, Willughby,-all of them already famous Englishmen-he makes no mention. Of the great accomplishments,Boyle's law, Newton's Gravitation theory, the Copernican system, the revelations of the microscope and the telescope-he is either ignorant, or wilfully omits them.

The effect of these satires was to sweep aside this vain controversy. It was not a victory for Temple and the Ancients, nor did it leave the field wholly in possession of the Moderns. This result was just what Swift must have desired: He had defended Temple and had shown the Moderns the unreasonable lengths to which their claims had gone.

As this period saw the defeat of witcheraft, the sweeping away of untenable physical hypotheses, and the banishment of a foolish reverence for antiquity, so it beheld the downfall of "judicial astrology". This pseudo-science, which clung like a parasite to the new philosophy, had long since lost prestige among the learned, ${ }^{158}$

155 The Battle of the Books (Everyman's Edition, p. 155-6).

156 Ibid. p. 160.

157 Ibid.

158 There were men, of course, who had not given it up entirely; for example John Dryden, who is known to have "inclined to a belief in it". For the famous astrologers of the day see supra, Chap. I, p. 20, note. 
but continued to hold sway over the ignorant by means of almanacmakers. It was Dean Swift, the man who defended Temple and the Ancients, that gave the death blow to this false doctrine in the so-called Partridge Papers. This famous practical joke upon Partridge is too well known to need extended discussion. It may be briefly shown, however, that it was a part of the struggle for the supremacy of reason and commonsense.

Swift defined his position on the question of astrology in his Predictions for the Year 1708. "I must add one word more: I know it has been the opinion of several learned persons, who think well enough of the true art of astrology, that the stars do incline, and not force the actions or wills of men $;^{159}$ and therefore, however, I may proceed by right rules, yet I cannot in prudence so confidently assume the events will follow exactly as I predict them". ${ }^{160}$ He then predicted among other things the death of Partridge "on the 29th of March next, at about eleven at night, of a raging fever". ${ }^{161}$ This trick of Swift's eaught the humor of London; the wits were curious to see Partridge hoisted with his own petard. In due time Partridge's death was announced in a detailed account of his last moments. The account found some credence in spite of Partridge's vigorous protest that "the reports were exaggerated".

Almanac-making did not cease with this incident, but judicial astrology. became a laughing-stock for the town. Commonsense with satiric lance had driven it from the field, so that it was henceforth "pensioned in dotage" among all those who pretended to learning. By this means another stronghold was taken by reason.

This survey of the conflict between the old and the new scientific ideas has been made by an examination of the salient examples. The discussion has constantly been centred upon the meeting of imagination and science. The conflict was far more permeating than that reaching into religion, moral and human philosophy, and politics. Nor did the conflict cease with the early years of the

\footnotetext{
${ }^{150}$ Burton's Anatomy of Melancholy, p. I; "They incline but do not compel . . . and so gently incline that a wise man may resist them. . . They rule but God rules them." Cf. Browne's Vulgar Errors, vol. II, p. 200; "There is in wise men a power above the Stars."
}

160 Swift's Works, vol. VIII, p. 402-3.

161 Ibid. vol. VIII, p. 443-4. 
eighteenth century, for new ideas, new physical conceptions must fight their way today. But this transition period has offered such phenomena as can be duplicated in more modern times only by the mid-years of the nineteenth century, when evolution first became a revolutionizing factor in human thought. The new ideas were making their way slowly toward an adequate literary expression, and toward a place of dignity in the minds of thinking men. With the last years of the seventeenth century there came a scientist whose genius was so superior, whose character was so irreproachable that all he did and all he said was looked upon with interest and attention. Men had only words of praise for Sir Isaac Newton.

Our study has revealed these facts: (1) The poets of the transition period, who were brought into close contact with the new scientific ideas, such as Cowley, Waller, Denham, and Sprat, were not able to throw off the yoke of conventional, outworn imagery of a discarded science. The influence of the new material upon them was surprisingly slight, both in inspiration and imagery. However much these men might support the new philosophy as thinkers, as poets they were uniformly of an earlier period of science. (2) In Milton was found the great scientific evasion, because he stood in doubt at the parting of the ways, distrusting the old and fearing the new. He was, therefore, forced to equivocate. Thus far, at least, he was a man of his period, and was fettered by the transition. (3) Here, too, was the final defeat of the longaccepted belief in witcheraft and sorcery among learned men; its last defense finding expression in the work of Joseph Glanvil, a man of unusually clear vision and sane judgment, and imbued with the new scientific spirit, but limited by inherited belief and superstition. (4) Likewise, there was the destruction of the power of ancient classical authority and a triumph for a "free and unpossest Reason". (5) Old false hypotheses, patched up with new facts but dimly understood, were fully refuted, as in the case of Thomas Burnet. It was in this destructive process that the "wary and circumspect disposition" of the scientists made itself felt most powerfully. (6) The pseudo-science of astrology was laughed to scorn by Swift, as Ben Jonson had earlier served alchemy. It was this new attitude of reason and commonsense 
entering into all the avenues of life that made men ready to discard the old idols and the "ancient faith".

Thus far, then, the men of imagination who had the best opportunity to know the new scientific ideas, with the exception of Glanvil and Burnet, show a general lack of appreciation of them and their literary possibilities. Milton, indeed, had found an infinite universe without abandoning the old science; to him the world had become a speck in space and man "an atom of an atomworld". But other poets had followed Hobbes's dictum,--"the subject of poetry is not natural science but the manners of men". ${ }^{162}$ The day had not yet fully dawned, "when, through the roof of the little theatre on which the drama of man's history had been enacted, men began to see the eternal stars shining in silent contempt upon their petty imaginings", ${ }^{163}$ or when "they began to suspect that the whole scenery was but a fabric woven by their own imaginations". ${ }^{164}$ And, finally, imagination had not yet overtaken reason, nor had the "framework of formulae gathered round it the necessary associations" for a direct expression of emotion, without the aid of an outworn hypothesis.

\footnotetext{
162 Hobbes, Thomas, Letter to D'Avenant, 1650.

163 Stephens, Leslie, History of 18th Century Thought, vol. I, p. 82.

164 Ibid. vol. I, p. 15.
} 


\section{CHAPTER III}

\section{The New Science ANd Comedy}

The new science did not escape the writers of comedy, who were constantly looking for some fresh, unexplored interest. It was, in truth, these "Wits and Railleurs" whom the virtuosi feared most of all, because their ridicule was more difficult to combat than the serious, but definite, opposition of others. The playwriters, moreover, were not careful, nor, indeed, were they desirous, to discriminate between true science and pseudo-science. Satirists do not look for the strong points in a new movement, but for its weaknesses. Almost inevitably, therefore, the new philosophy would be held responsible for all the absurd things done in its name; experimental science must support the follies and chicanery of pseudo-science and superstition. In this occult science there was a legitimate field for satire, because the whole basis was false and the professors of it were charlatans and imposters. The comic spirit had, in fact, entered the field of occult science long before the organization of the Royal Society. In 1610, Ben Jonson had held up Subtle, the alchemist, to public ridicule, and had made men ashamed to profess this "humour" seriously. But the new philosophy, also, was opposed to such false pretentions; and, while alchemy continued, ${ }^{1}$ with declining power, through the seventeenth century, the new demand of experimental science for natural causes tended to destroy the foolish hopes of turning the baser metals into gold and to discourage the absurd search for the philosopher's stone. ${ }^{2}$ Subtle, in The Alchemist, could not, therefore, be classed among the new Baconian philosophers, and Ben Jonson's satire was not pertinent in the Restoration period. ${ }^{3}$

With astonishing pertinacity the belief in witcheraft and sorcery held a place in the minds of men and found defenders even among the new philosophers. Bacon had early attempted to give scientific explanation of it ${ }^{4}$ Boyle confessed his faith in it;

1 Cf. Ashmole's Theatrum Chymicum; also, chap. I, p. 21.

2 Boyle, Sir Robert, Sceptical Chymist.

${ }^{3}$ The Alchemist was revived in 1663 , Pepys saw it in 1664, August 3d. It reappeared as The Empiric in 1672.

4 Traill, H. D., Social England, vol. IV, p. 87.

5 Boyle, Usefullness of Experimental Philosophy, p. 238. 
Glanvil declared that to doubt it was the first step toward atheism. ${ }^{8}$ This connection with the new science brings the satire against it within the scope of this investigation. "The well-known trials of the Lancashire Witches occurred in 1613, and again in 1634'". Comedy immediately took up the subject. Thomas Heywood's play, The Lancashire Witches, appeared in 1634, satirizing the trials; W. Rowley used the same theme in his Witch of Edmonton, 1658. Thomas Shadwell, in 1682, presented a play with the same title as Heywood's, The Lancashire Witches, in which an ingenious use is made of the power of witches to transform individuals into various shapes. There is no satire here, but in the introduction Shadwell wrote; "For the Magical Part, I had no Hopes of equalling Shakespeare.... There is not one action in the play, nay, scarce a word concerning it, but is borrowed from some ancient or modern Witchmonger, which you will find in the Notes, wherein I have presented you a great part of the Doctrine of Witcheraft, believe it who will. For my part, I am (as it is said of Surly in the Alchemist) somewhat costive of Belief". 8 The struggle of this superstition against the principles of the new science was so far lost in 1715 that Addison could make sport of it in his comedy, The Drummer, where the secret rapping of the spirit of the departed is shown to have a very natural, flesh-andblood origin.

Another pseudo-science, astrology, found many believers through the seventeenth century, but not among the new philososphers. For them the telescope had so far removed the superstitious awe of the heavens that Thomas Burnet could say, 1687,"I do not see how we are any more concerned in the Postures of the Planets than in the Postures of the Clouds".9 Comedy had already discovered the sham and pretense, for John Wilson satirized astrology in The Cheats, 1662. Mopus, in this comedy, is an astrological physician, and of course a quack, who showed himself of "no ordinary learning" in an advertisement which he posted;

' Glanvil, Joseph, Sadducismus Triumphatus.

7 Traill, H. D., Social England, vol. IV, p. 86.

${ }^{8}$ Shadwell, Thomas, Dramatic Works, vol. III, preface to Lan. Witches.

- Burnet, Thomas, Sacred Theory, vol. II, p. 38 . 
"As also (to let the world see how wide of their mark they are like to run that as boldly as ignorantly dare adventure on physic without the knowledge of astrology) I resolve the ensuing astrological questions. The sick, whether they shall recover or not; the party absent, whether living or dead. How many husbands or children a woman shall have, etc. etc., (Signed) A servant of God, and Secretary of Nature, Iatros Iatrophilus Mopus'". ${ }^{10}$ This character has some of the meaningless jargon that imposed upon the ignorant. To him a watch is a "trachleal horodeixe", an inkstand becomes a "ligneous pixid accommodated with two plumbeous recepticles or stormeous repositories for ink and sand". ${ }^{11}$ " 'Tis the way of the learned. Term is three-quarters of the Art". The claims of his ability are unlimited. "I wonder my boy comes not. I have sent him for a rosycrucian preparation has fetcht a man again after he has been dead a day and a half'". ${ }^{12}$ Mopus is plainly intended for a charlatan of the worse sort.

John Dryden used two astrologers most eleverly in the prologue to The Wild Gallant (1663), to forecast the success of the play. Again, taking freely of foreign material, he produced his comic situation in An Evening's Love (1665) by means of a "mock astrologer". His skillful use of the technical terms of this pseudoscience caused Sir Walter Scott to comment;- "Our author's use of the terms and technical phrases of judicial astronomy intimate his acquaintance with that pretended science, in which he is known to have placed some confidence". ${ }^{13}$ But whatever Dryden's private belief, he does not here defend or satirize this pretended science, nor does he in any way connect it with the new science. The author knew well enough that astrological studies were not pursued by the members of the Royal Society.

In all of these comedies the new science is not represented; nor in any instance is the material new or from contemporary English life. The interests of the new philosophers lay elsewhere, and only

- through ignorance of their designs and work could these characters be classed with them. There was one phase of their interest, how-

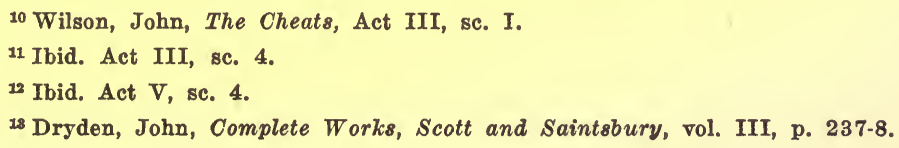


ever, that had been alive for many years even at the time the Royal Society was formed. It had straightway become a "humour" and found itself represented in comedy as early as 1641, in Shackerley Marmion's The Antiquary. ${ }^{14}$

Veterano, the Antiquary, does not indeed perform experiments; he knows nothing of such modern scientific apparatus as the telescope. He embodies, however, the wide-spread interest in collecting "rarities". As has been shown, this was an age of historical research; "antiques", ancient and modern, suddenly took on an enhanced value. The wits were quick to see the possibilities for comedy here; and, since the new philosophers aided and abetted this search for curiosities, it will be necessary to present this early antiquary and his successors somewhat in detail. Veterano is thus characterized by his nephew, Lionel, who in true comic fashion has designs on the old man's money,- "He is grown obsolete, and 'tis time he were out of date. They say he sits all day in contemplation of a statue with ne'er a nose, and doats on decays with greater love than the self-loved Narcissus did on his beauty". ${ }^{15}$ Veterano is of course made the scapegoat in the play. Having been tempted to drink too much, he lets himself be dressed as a fool and thus brought before the Duke. In this maudlin condi. tion he declares the breeches he wears once belonged to Pompey; the hat on his head was the possession of Julius Caesar; the spectacles astride his nose were worn by Hannibal when crossing the Alps. When he becomes sober enough to realize the ridiculousness of his garb, he is mollified only by the assurance that the fool's coat "did once belong unto Pantabolus the Roman Jester, and buffoon to Augustus Caesar". False antiques,-an old manuscript found in a wall, a book of mathematics-are palmed off on him at a handsome price. In his "sacred room" are found "a porirait of the sibyls", Venus and Cupid by Appelles, Hercules, Antaeus, Pallas, Jupiter, "a silver box that Nero kept his beard in", and an urn containing the ashes of the Emperors. The Duke, conniving with the Antiquarian's nephew, declares the collection of "rarities" is to be confiscated because their value is such that no private citizen should be permitted to own them. Thereupon Vet-

${ }^{14}$ Dramatists of the Restoration, vol. I, Shackerley Marmion.

${ }^{15}$ Act I, sc. 1. 
erano in despair wills his property to Lionel. He is altogether a despicable fool, the gull and dupe of everyone. But the sharpest satire underlies this dialogue between the Antiquary and his servant Petro.-

"Antiquary,-The very dust that cleaves to one of those monuments, is worth more than the ore of twenty mines!

Petro,-Yet, by your favour, Sir, of what use can they be to you?

Antiquary,--What use? Did not the Seigniory build a Statechamber for antiquities? And 'tis the best thing that e'er they did; They are the registers, the Chronicles of the age they were made in, and speak the truth of history better than a hundred of your printed commentaries". ${ }^{16}$

But in spite of such ridicule the interest in antiquarianism, as the search after all sorts and conditions of rarities and curiosities was called, increased through the succeeding years, and Veterano reappeared under the name of Sir Arthur Oldlove in Durfey's comedy, Madam Fickle, 1677. A glimpse into Oldlove's relic room is given in this play, where there is a "table with a skull, sword, vial, shooing horn, box, and picktooth". ${ }^{17}$ The skull, Oldlove declares, was one set on the shoulders of St. Gawain of the Round Table; the sword belonged to "Sir Lancelot du Lake"; the "shooing horn", the very first ever invented, "was left by the Queen of Sheba in Jerusalem when she visited Solomon"; the box, like Veterano's, contained Nero's beard; the vial was full of the tears of St. Jerome. The dramatist apparently forgot the "picktooth", or else his invention failed him.

Here is a full grown humor.

"As when some peculiar quality

Does so possess a man, that it does draw

All his affects, his spirits, and his powers

In their confluctions, all to run one way,

This may be truly said to be a humour". ${ }^{18}$

So it is with Oldlove. "Is there anything", he asks, "more pleasant than antiquities? The Knowledge of the distinction of the

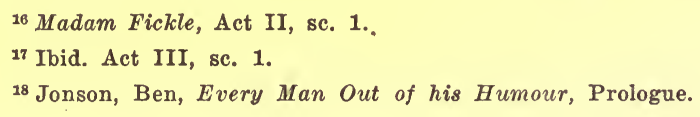


Ages, or the deeds and manners of the Ancients, I say, is there anything more pleasant?". ${ }^{19}$ "Rust adds to Antiquity; 'tis our Friend". ${ }^{20}$ Nothing that is new can please him, because it is new; all that is old delights him, because it is old.

Years afterward, in the eighteenth century, this character came again on the comic stage. The antiquarian interest was still alive, so that the "humor" could be appreciated by the audience. In 1773, Foote wrote a comedy entitled The Nabob. There is presented, in Act III, a meeting of the Society of Antiquaries at which Sir Matthew Mite, the Nabob, is elected president because he has discovered the secret meaning of "Worthington's eat". ${ }^{21}$ Sir Matthew is merely the resurrected Sir Arthur Oldlove in a new comic situation. Once more, just at the close of the century, 1798, John O'Keefe presented this old-time antiquarian "humour" in his Modern Antiques. But this has alreâdy extended far beyond the limits of our period.

Certain common characteristics of these comic representations are to be noted. In the first place, all the antiquaries are men of wealth; Veterano has a fortune which his nephew wants; Oldlove has thousands of pounds to spend for rarities; Sir Matthew Mite is exceedingly rich; the purchaser of "modern antiques" has only a fortune to recommend him. They are all persons of noble rank, or pretend to be so; Veterano is a noble, Oldlove likewise; Sir Matthew Mite shams nobility. And, in point of fact, the antiquarian interest belonged to the English gentlemen, for they alone had time to pursue it. The Society of Antiquaries was a Gentlemen's club. Furthermore, there is constant complaint in the comedies that much money is wasted in these investments in antiques, too often "modern antique", which might have been put to better use. There is no benefit to be derived from such pursuits, those unbitten by the humor declare, either to the collector himself or to mankind. They could not be expected to see that this spirit of inquiry, carried to a foolish extent in many cases certainly, this desire to collect relies of a by-gone age and to find a means of classifying them so as to interpret that former life,

\footnotetext{
10 Madam Fickle, Act III, sc. 1.

20 Ibid.

21 It means a cat-boat.
} 
would lead on the one hand to the writing of history and on the other hand to the study of Botany, Zoology and Geology. To the play-writers the search for old manuscripts, for antiques of literature, for art relics, for old coins, was only a transient fad. In reality it was an essential part of the new scientific movement whereby the natural history of the world was to be reconstructed. If no experiments were needed, yet careful observation was required, which was an equal part of the Baconian injunction. The antiquarians must find a place, therefore, among the new philosophers.

But the first real virtuoso, the comic archetype of the "tribe", appeared in Thomas Shadwell's comedy, The Virtuoso, 1676. Langbaine says,_- "No man ever undertook to discover the Frailties of such Pretenders to this kind of Knowledge before Mr. Shadwell". The author himself lays claim to originality in his characterization, in the prologue.

"In this are Fools, that much infest the town,

Plenty of Fops, Grievances of this Age,

Whose nauseous Figures ne'er were on the stage.",22

$\mathrm{He}$ is correct so far as purely experimental science and "PhysicoMechanical Inventions" are concerned, but one essential phase of the new scientific interest has already been discovered. Sir Nicholas Gimcrack is, however, the most complete comic conception of the new philosopher, and as such demands full consideration.

This virtuoso is without honor in his own country; his friends and relatives, with the exception of his admiring wife, do not hold him in esteem. Snarl, the cynic, says of him,-- "My nephew is such a coxcomb, he has study'd these twenty years about the nature of Lice, Spiders, and Insects". ${ }^{23}$ His friend Sir Samuel Formal, Rhetorician, asserts,-_ "He is an enemy to wit as all Virtuoso's are". Clarinda calls him "a sot that has spent $£ 2000$ in Microscopes, to find out the Nature of Eels in Vinegar, Mites in Cheese, and the Blue of Plums". "One, who has broken his Brains," adds Miranda, "about the Nature of Maggots, who has study'd these twenty years to find out the spots of a Spider, and never cared for understanding Mankind". Longvil, who has some

22 The Virtuoso, Prologue.

2 The Virtuoso, Act I, sc. 1. 
reason to denounce him, declares,-_" "I would rather be a Trumpeter to a Monster, and call the Rabble to see a calf with six Legs, than such a Blockhead." These opinions are not the offspring of envy, for Sir Nicholas has aroused no jealousy save among those philosophers at Gresham College. "The College indeed refus'd him; they envy'd him". ${ }^{24}$

The occasion of this general contempt becomes obvious when the virtuoso is revealed in his laboratory, "a spacious Room, where all his Instruments and fine Knick-knacks are". ${ }^{25}$ These "fine Knick-knacks" include microscopes, telescopes, thermometers, barometers, "pneumatick Engynes", "stentrophonical Tubes", fragments of dead insects scattered about, and special colonies of live ones in a corner. Into this room Shadwell has collected all the new laboratory apparatus of the Royal Society which he knew, just as he combined all its interests in this virtuoso. When the scene opens Sir Nicholas is in the midst of one of his ridiculous experiments; he is learning to swim by lying on the table and imitating the actions of a frog in a dish of water in front of him. "A most compendious method", announces Sir Formal, "that in a fortnight, has advanced him to be the best swimmer of Europe. Nay, it were possible to swim with any fish of his inches." But it suddenly occurs to Longvil to enquire,- " "Have you ever tried in the Water, Sir?"

Sir Nicholas,-_"No, Sir, But I swim most excellently on land". Bruce,-Do you intend to practice in the Water, Sir?

Sir Nicholas,-Never, Sir, I hate Water. I never come upon the Water, Sir.

Longvil,--Then there will be no use of swimming.

Sir Nicholas,-I content myself with the speculative Part of Swimming. I care not for the practick. I seldom bring anything to Use; 'tis not my Way. Knowledge is my ultimate End'. ${ }^{26}$

This quip at the close is the sharpest eriticism that was ever launched at the devotees of the new experimental science./Again and again the question of immediate use was asked; and there the defense was weakest. The microscope and the telescope had re-

24 Ibid. (Lady Gimcrack).

25 Ibid. Act II, sc. 1.

28 The Virtuoso, Act II, sc. 1. 
vealed new worlds; there were everywhere fresh fields of investigation; the minds of the scientists were constantly piqued with curiosity; there was a continued search for some new thing;but, naturally enough, thoughts of the "Practick" came only after curiosity had been satisfied.

The next experiment, however, was one to appeal to the imagination and to suggest the practical application of it. In the transfusion of blood, which Sir Nicholas has brought to "the Achme of Perfection", the most extravagant results were hoped for. Dreams of eternal youth were entertained; the possibility of an entire transformation of the natural characteristics was thought to have been discovered. Sir Nicholas had transfused the blood mutually between a mangy spaniel and a sound bull-dog, "making both Animals to be Emittent and Recipient at the same time". ${ }^{27}$ The effect was astonishing; not only did the spaniel become sound and the bull-dog mangy, but also the spaniel became a bull-dog and the bull-dog a spaniel. The recent experiment of a French Academician of transfusing the blood of a sheep into the veins of a madman fell far short of what this virtuoso had done. His patient "from being Maniacal, or raging, became wholly Ovine or sheepish; he bleated perpetually, and chew'd the Cud. He had wool growing on him in great quantities". ${ }^{28}$

Sir Nicholas had promised to dissect a "Chichester Lobster" for his visitors, but unfortunately the fishmonger failed to appear. The dramatist's reasons for omitting this operation are not clear, but several suggestions at once occur. Shadwell may not have known enough about the anatomy of the lobster, or he may have thought the thing would not be practicable on the stage. The promised lecture on science also is given up, and doubtless for the same reasons. Neither one would have made a good scene.

The strangest experiment of all is that of bottling the air. Sir Nicholas has an ingenious scheme for taking the country air while sitting at home in the midst of London. He has men employed in all parts of England-"Factors of Air"- - to bottle the different varieties and send them to him to be stored in a great vault under his house. He has collected large quantities from Newmarket,

$$
{ }^{27} \text { Ibid. }
$$


Banstead Down, Wiltshire, Bury, Norwich,-_"what you will". ${ }^{29}$ His custom is to choose the particular kind of air desired, and then, going into his chamber, to close the windows and doors, and draw the blinds. He now opens some forty gallons of the chosen air and snuffs it up eagerly with such exclamations as- " $O$, this Bury air is delicate! 'tis delicious! 0 , very refreshing!" "There is great advantage in thus taking the air for it tastes so much fresher from being bottled, as Liquors do. For, let me tell you Gentlemen, Air is but a thiner sort of Liquor".

He also weighs the air carefully. From his thorough study he can tell exactly the weight of a given amount from any district. That around the "Picque of Teneriffe is lightest in weight; from Sheerness and the Isle of Dogs comes the heaviest".

"Longvil,--To what end do you weigh this Air, Sir?

Sir Nicholas,-To what end should I? To know what it weighs. O, Knowledge is a fine thing!"'30

Other experiments in Physics had been made. The virtuoso produces his pneumatic engine, which, according to his own boast, he has used to "eclipse the Light of rotton Wood . . . . . and putrid Flesh, when it becomes lucid". "Tis the finest Light in the World. But for all that I could eclipse the Leg of Pork in my Receiver, by pumping out the Air; but immediately upon the Applause of the Air let in again, it became lucid as before."

"Longvil,--Is it so curious a Light?

Sir Nicholas,-I am now studying the Glow-worms; a fine Study! Curious Animal, I think I shall preserve them Light all the Year, and then I shall never use any other Light in my Study but Glow-worms and concave Glasses. . . I myself have read a Geneva Bible by a Leg of Pork'". ${ }^{31}$

He has also made experiments with the wonderful properties of May-dew; he is an adept in the rosicrucian mysteries; he is a physician who cures by general prescriptions. He delves into experimental science and pseudo-science alike and without discrimination. It was evidently Shadwell's purpose to make the whole realm of scientific investigation ridiculous. To this series of absurd ex-

29 The Virtuoso, Act. V, sc. 1.

so Ibid. Act II, sc. 1.

The Virtuoso, Act V, sc. 1. 
periments he added extravagant claims of achievements. He comes here near to the quarrel between the moderns and the ancients that was fought out a little later. Sir Nicholas seems to have far outstripped all the ancient and modern scientists; in most things he has reached "the Achme of Perfection".

In the study of insects there is the most sport for the dramatist; it is the most thoroughly canvassed comic element in the play. Special attention has been devoted to the ants, where the virtuoso has "discovered more curious Phenomena in these Animals, than in those of vaster magnitude". ${ }^{32}$ He knows their form of government, "which is a kind of Commonwealth, a Republic, resembling that of the States-General". Spiders have revealed to him more curious "Appearances of Nature, than to any man living". ${ }^{33}$ One spider had been so well trained that he recognized his name, "Nick", and followed Sir Nicholas around as a dog does its master. ${ }^{34}$ He has made a thorough investigation of "the delicate Spider, call'd Tarantula"; he has "travelled all over Italy, and had no other Affair in the World, but to study the Secrets of that harmonious Insect."

"Bruce,-Did you observe the Wisdom, Policies, and Customs of that ingenious People?

Sir Nicholas,-By no means. 'Tis below a Virtuoso to trouble himself with Men and Manners. I study Insects'". ${ }^{35}$

Snarl says that he cares not for this new philosophy, because it consists in good-for-nothing experiments upon flies, maggots, eels in vinegar, and the blue upon plums. ${ }^{36}$ The world of minutiae disclosed by the microscope meant only this to the play-writer.

The telescope has revealed the most marvelous things in the moon to the virtuoso. He has seen the mountains and valleys, seas and lakes of that place; he has recognized the larger animals, such as elephants and camels; he has been able to identify public buildings and ships. But the half has never been told;- "I have seen several Battles fought there. They have great guns, and have the

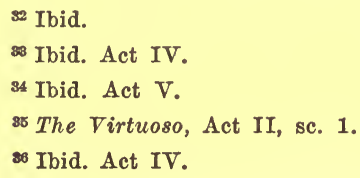


use of Gunpowder .... . There is now a Great Monarch who has Armies in several Countries of the Moon; which we found out because the Colours, which we see, are all alike. There are a great many States, which we take to be Confederacies against him. He is an ambitious Prince, and aims at universal Monarchy, but the rest will be too hard for him". ${ }^{37}$ The force of nature ean hardly go further than this.

A servant interrupts the Virtuoso's discourse on insects, by entering to announce,- "Sir, the Gentleman that's going for Lapland, Russia, and those parts, is come for your Letters and Queries, which you are to send thither". "Sir Nicholas;-I'll wait on him. I keep a constant correspondence with all Virtuoso's in the North and North East Parts. There are rare Phenomena's in those countries. I am beholden to Lapland, Finland, and Russia for a great part of my Philosophy. I send my queries there.",38

This custom was actually followed by the members of the Royal Society. In the first place the entire company was divided into committees, and a definite field of inquiry was assigned to each. Then, in order that they could keep in touch with scientific activities in other parts of the world, a system of correspondence was kept up. Oldenburg, the first secretary, complained because he was heavily burdened with the correspondence he was obliged to carry on. Letters poured in upon him from Italy, Spain, France, America, Germany, Holland, Sweden, Scotland, Ireland, Japan, China, Persia, and Turkey. From time to time long lists of queries were sent out by travellers to be answered either by themselves or by some scientific friend in the foreign parts. Visiting foreigners were formally invited to the meetings, and were often asked to address the Society.

Such a custom was destined to have a note-worthy effect./ So far from being the correct material for satire, it deserved high praise. Of course it had its weakness; many of the reports received were of the most fabulous character, yet they were represented to the Society and recorded in their minutes. This laid them open to satiric attack. The idea of such a system of international communication originated with Lord Bacon's New Atlantis. The

a7 Ibid.

28 Ibid. 
king of the Isle of Bensalem sent out groups of men, whom he called Factors, to make a study in all parts of the world of certain natural phenomena. It might be added that the whole pattern of the Society may be found in the same book. The humor in the mentioning of such places as Finland, Lapland and Russia is almost wholly lost on the modern reader. To the seventeenth century mind it was civilization asking barbarism and superstition to solve its perplexing problems for it.

Although, in general, knowledge is itself the ultimate end for Sir Nicholas, yet he has applied his skill to some practical inventions. He has gone far beyond anyone in improving the telescope. It was due to his superior apparatus that he could see so many more things than other observers. He. has improved the speaking trumpet "beyond all men's expectation" already, and hopes within "three months to improve it so that from a chief Mountain, Hill, Eminency, in a County, a man may be heard around the Country". The result will be that one person can preach to a whole county, and the King will be able to "take the Church Lands and serve all England with its Chaplains in Ordinary". 39

Bacon had declared that a man could, by study of nature, become complete master over her. Into this belief Sir Nicholas has fully entered;-“" "a man by Art, may appropriate any Element to himself. You know a great many Virtuoso's can fly; but I am so much advanced in the Art of flying, that I can already outfly that ponderous Animal call'd a Bustard; nor can any Grey-Hound in England catch me in the calmest Day, before I get upon Wing. Nay, I doubt not, but in a little time to improve the Art so far, 'twill be as common to buy a Pair of Wings to fly to the World in the moon, as to buy a Pair of Wax-Boots to ride into Sussex with". ${ }_{40}$

So learned is this virtuoso, at least in his own esteem, that ordinary words will not afford him free expression; he must have a "learned language". His dissertation at his first appearance, where he is learning the art of swimming, will serve as an example of the extravagance of his speech. "Let me rest a little to respire.

${ }^{30}$ The Virtuoso, Act V, sc. 2.

${ }^{40}$ Ibid. Act II, sc. 1. 
So ; it is wonderful, my Noble Friend (the French Dancing-master), to observe the Agility of this pretty Animal, which notwithstanding I impede its motions, by the detention of this Filum, or Thread, within my Teeth, which makes a ligature about its Loins, and though by sudden stops I cause the Animal sometimes to sink or immerge, yet with indefatigable Activity it rises, and keeps almost its whole Body upon the Superficies, or surface of this humid Element". ${ }^{41}$ Later, in explaining respiration, he declares the air is expelled from the lungs "farther to elaborate the Blood by refrigerating it, and separating the fuliginous Streams". He talks familiarly of the "follicular impulsion of Air", of the "Chrystalline from the coagulation of the Aqueous Juices", of "heterogeneous and homogeneous", "emittent and recipient", "cacochymious", "fluidity", "orbiculation", "fixation", "angulization", "plantananimation". Many of the recently coined scientific polysyllables are sown through his speeches in a wanton manner.

In the final scene Sir Nicholas Gimerack finds himself deserted by everyone; even his wife has turned against him when his money is gone. She threatens to publish his letters "and send them to Gresham College", where he will be "more despised than he now is there". All of his property is taken to pay for his instruments and the expenses of his experiments; a mob of weavers have threatened to take his life for inventing a loom to displace them. Under these circumstances he repents of his humor. "That I should know Men no better; I would I had studied Mankind, instead of Spiders and Insects.-Am I deserted by all? . Well, now 'tis time to study for Use; I will presently find out the Philosopher's Stone; I had like to have found it last Year, but that I wanted May-Dew, it being a dry Season"..42

"The Virtuoso, who piques himself on never intending anything that is of use, is certainly a very good character, but the scenes in which he explains his experiments, must be very heavy in presentation". ${ }^{43}$ This is just criticism; the character is good, but there is too obvious an attempt to get in all the possible hits on the new science. There are scenes, however, where Sir Nicholas

1 The Virtuoso, Act II, sc. 1.

42 The Virtuoso, Act V, sc. Ultima.

to Genest's Some Account of the English Stage, vol. I, p. 888-9. 
is not consistently possessed with this new humor, where he is not a scientist but a man about town, engaging in base intrigues like other comic characters. (Longvil) "For all his Virtue and Philosophy, this grave Fool will be in the fashion too". ${ }^{44}$ Into these scenes the dramatist did not bring his science as he brought Sir Formal with his Rhetoric, and Snarl with his hatred of everything later than 1642. Sir Nicholas must be in his laboratory, surrounded by his apparatus, his flies, spiders, mites and maggots, or his is an ordinary, indistinguishable comic character. His scientific humor, therefore, is superficial; it is obviously tacked on to him and not an essential part either of him or of the plot. The point is that Sir Nicholas is a pretender to this scientific knowledge and it is this pretense against which the satire is aimed, and not against the true-blue Greshamites.

Although Sir Nicholas Gimerack is Shadwell's master effort, he did return in other comedies to touch upon the scientific humor. In the Squire of Alsatia (1688) the father and the uncle of the young squire discuss the benefit of natural philosophy in the education of a gentleman.

"Sir Edward,- - He by the way read Natural Philosophy, and had an insight enough into Mathematics.

Sir William,-Natural Philosophy! Knows nothing; Nor would I give for any Mathematician, but a Carpenter, Bricklayer, Measure of Land, or a Sailor.

Sir Edward,--Some moderate skill in it will use a Man to reason closely.

Sir William,-Very Pretty, Reason! Can he reason himself into six Shillings by all this?"45

In The Sullen Lovers, 1688, there is a "virtuoso in the character of Lady Vaine Knowall". She prides herself upon her mercurial disposition. "On my conscience", says Lovell, "it is easier to fix quick-silver than your Humour, Madam".46 This capricious vivacity is really her humor, even although she pretends to knowledge extraordinary. "That Virtuosa, as calls herself, is the pleasantest creature I ever saw". ${ }_{47}$ In reality there is only a claim to

4t Act III, sc. Ult.

${ }^{45}$ The Squire of Alsatia, Act II.

*8 The Sullen Lovers, Act II, sc. 1.

${ }^{47}$ Ibid. Act II, sc. 1. Caroline. 
virtuosity. "Madam", says Lady Vaine, "d'ye think I, that am a Virtuosa, understand no better than to leave you, now you are not well?" ?8 But she has no experiments to show, no discoveries to disclose. She is only a "she-pedant" with a vague idea of what learning consists. A far more direct thrust at the new philosophy is given by Emilia,- "Others, after twenty or thirty years study in Philosophy, arrive no further than at the weighing of carps, the invention of a travelling wheel, or the poisoning of a Cat with the Oyl of Tobacco; these are your Wits and Virtuoso's". In the last act of the play it is stated on hearsay evidence that Sir Positive-At-All can fly; this is distinctly a virtuoso's acquirement.

The new science appeared later in Mrs. Aphra Behn's The Emperor of the Moon (1687). Dr. Boliardo, having spent a long time in the study of the "lunar orb", "so religiously believes there is a world there, that he Discourses as gravely of the People, their Government, Institutions, Laws, Manners, Religion, and Constitution, as if had been bred a Machiavel there". ${ }^{49}$

"Scaramouch,-How came he so infected?

Elaria,-With reading foolish Books, Lucian's Dialogues of the Lofty Traveller, who flew up to the Moon, and thence to Heaven; an Heroick Business called the Man in the Moon, if you'll believe a Spaniard, who was carried thither, upon an Engine drawn by wild Geese; with another philosophical Piece, A Discourse of the World in the Moon; with a thousand other ridiculous volumes too hard to name". ${ }^{50}$

A play, called The Man in the Moon, is to be presented before the moon-struck doctor with such realistic setting that he will be convinced of its reality. ${ }^{51}$ The purpose is to bring about an opportunity for the two young gallants to meet with the closely guarded young women, with whom they are in love. The doctor, with all his moon gazing, is jealous of any attention paid his wards.

In the second scene of Act II Doctor Boliardo enters "with all manner of mathematical Instruments hanging at his girdle; Scaramouch bearing a Telescope twenty or thirty feet long". This

48 Ibid. Act II, sc. 1.

49 The Emperor of the Moon, Act III.

${ }^{50}$ Ibid. Act I.

61 Ibid. Act I, sc. 1. 
telescope is pointed at the moon ready for new observations, but at that moment a visitor is announced, who proves to be a learned member of the virtuoso society in the moon, "a Cabalist of the Rosicrucian Order". In reality it is Charmante in disguise. The doctor and the stranger talk learnedly about the "Caballa of Eutopia"; a map of the moon-world is displayed, omitting "no Town, Village, or Villa; no Castle, River, Bridge, Lake, Spring, or Mineral".52 "Keplair and Galileus" enter "with Perspectives in their Hands"; they are come as "interpreters of the Emperor of the Moon". ${ }^{53}$ They say nothing themselves but only by means of an interpreter who uses a "stentrophon" (the "stentrophonical tube" of Sir Nicholas). At the end of the comedy Doctor Boliardo stands alone with the realization that his two wards have been stolen and he himself has been duped. "I see" he says, "there's nothing in Philosophy. Of all that he was the wisest Bard, who spoke this mighty Truth-

He that knew all that ever Learning writ,

Knew only this,- that he knew nothing yet".

It is difficult here to disentangle the new from the old studies of the moon. Doctor Boliardo is in part the old-time astrologer with new scientific apparatus,- "'his Microscopes, his Horoscopes, his Telescopes, and all his Scopes". But his brain has been cracked by the perusal of extravagant fiction, foreign and domestic, respecting the moon. Among these books is one by Dr. Wilkins, $A$ Discourse of the World in the Moon, who was a shining light in the Royal Society. It would seem fair to conclude that the dramatist had as confused an idea of the new science as Doctor Boliardo himself. She knew no distinction between astrology and astronomy.

The new science did not escape the comprehensive satire of the Rehearsal (1664-1667).

"Johnson,-But they are a new kind of Wits.

Smith,-New Kind! What Kind it that?

Johnson,-Why, your Virtuosi, your civil Persons, Your Drolls." ${ }_{54}$

${ }^{82}$ Ibid. Act II, sc. 3.

$\$$ Ibid.

${ }^{54}$ The Rehearsal, Act I, sc. 1. 
"Bayes,-A friend of mine at Gresham College has promised to help me to some Spirit of Brains." "55

These are but chance references and are practically negligible, except for the rather important fact that they could persumably be understood by all play-goers. Allusions to the new science, like those to puritanism and the "Good Old Cause", are made without appended explanations. As early as 1664 sufficient knowledge of what the Greshamites were doing had spread through London to make it a familiar source of allusion for wits.

John Lacy's The Dumb Lady appeared in 1672. "The main plot is taken from Molière's Mock Doctor; the catastrophe is borrowed from Molière's Love's the best Doctor'".56 And yet a little of the English science has erept into the character of Drench to give a touch of local color. Isabella praises his ability as a physician most extravagantly,_- "he brought a mad-woman to her wits again that was suspected never to have had any; nay, he has taken men's legs and arms off, and set 'em on sound again',.57 Jarvis thereupon declares "that's beyond Surgeon's Hall".

"Softhead,-I'll be hanged if this fellow be not a spy of the virtuoso's and is come to betray the sectreat of Nature". ${ }^{58}$

The farrier, Drench, once turned physician, goes the full course. By happy fortune he is endowed with remarkable wit, and having once served a montebank, who had taught Drench, had learned something of the "fanatic branches" of the new science.

"Gernette,-But, Sir, 'tis strange that you should know my daughter's disease from my pulse.

Doctor,-Sympathy does it. I find you have no faith in sympathetic powder, therefore, cannot know our sympathetical way of practice. When any man or woman is sick in Greenland, they always send the next of kin to the doctor; and by that pulse the disease is known and the patient cured. ......

Doctor,-Why, Sir, your men that have endeavored to find out perpetual motion have come near it, I confess, with their clocks and pendulums; but Aristotle says, Fix a dial plate to a woman's

$\omega$ Act II, sc. 1.

${ }^{50}$ Dramatists of the Restoration, John Lacy, Note to the Dumb Lady.

${ }^{57}$ Ibid. Act I, sc. 2.

${ }^{68}$ Dramatists of the Restoration, John Lacy, The Dumb Lady. Act. I, sc. 2. 
Mouth, and if the perpetual Motion be not there, let them never hope to find it". .59

In his practice as a physician, Drench, like the Greshamites, "works by natural sauses". ${ }^{60}$

The process here is obvious. Lacy has succeeded in pouring a little new wine into the old wine-skins without loss. He freely confesses his obligations to other wits and apologizes for his adaptations on the ground that he cannot help it. "There is a kind of charm in poetry-'tis like tobacco and chemistry; for if you once take the one and undertake the other, you are fixed to the freehold never to be parted". ${ }^{61}$ The dramatist has gathered a few scraps from the table of the new scientists and patched up the old character of the astrological physician.

This comic situation and this character reappear in Mrs. Centlivre's Love's Contrivance (1703), and in Fielding's Mock Doctor (1732). In the latter comedy Gregory, as Drench is there called, has a touch of the new science in him. He had once been a servant at the university, and being quick of wit, had absorbed some Latin and some scientific jargon.

"Gregory,-Sir, I can cure anything. Hark ye, Mr. Apothecary, you see that the love she has for Leander is entirely contrary to the will of her father, and that an immediate remedy is necessary. For my part, I know of but one; which is a dose of purgative running away, mixt with two drams of pills of matrimoniacy and three large handfuls of arbor vitae; perhaps she will make some difficulty to take them; but as you are an able apothecary, I shall trust you for the success. Go, make her walk in the garden; be sure to lose no time; to the remedy quick; to the remedy specific.

Sir Jasper,-What drugs, Sir, were those I heard you mention, for I don't remember I ever heard them spoke of before?

Gregory,-They are some, Sir, lately discovered by the Royal Society". ${ }^{62}$

59 Ibid. Act II, sc. 1.

60 Ibid.

1 Epistle to the Reader.

${ }^{62}$ The Dumb Lady, Act II. 
An amusing travesty on dissection is found in Ravenscroft's The Anatomist; or the Sham Doctor (1697). The comic situation is conventional enough. Old Gerard loves the young daughter of Monsieur Le Medecin, whose wife and daughter by the way are wholly English in name and speech. The doctor consents to the match for money; but the wife, who "wears the breeches", refuses. Young Gerard, who has been sent to college to prevent his becoming a rival to his father, loves Angelica, and is loved by her. Crispin, the mock doctor, is the servant of young Gerard and in love with Beatrice, the servant of Angelica. These two servants carry on the intrigues. Two of the scenes are laid in the laboratory where a body is to be brought for dissection. Crispin is first caught in here by Monsieur Le Medecin and is compelled to lie on the dissecting table simulating the corpse for dissection. The only thing that prevents his discovery or dismemberment is the hiding of the doctor's instruments by Beatrice. Once out of this predicament he resolves never to undergo such an experience again. The doctor returns before he can escape; he dons the dress of a physician, which he finds hanging on the wall, recalls a few phrases that he heard while lying on the table, and pretends to be a physician come to witness the dissection. Crispin is now the sham doctor,-_"medicus sum" -with a suddenly developed knowledge of astrology. He considers himself no unworthy member of the profession. "The world belies 'em or there are many physicians as great fools as myself". ${ }^{63} \mathrm{He}$ compels Old Gerard, who has come clandestinely to see Angelica, to lie on the dissecting table to avoid detection. Thereupon he frightens him with threats of "amputation" and "incisions", of deep carvings from the "Systole to the Diastole". He dispenses pills to all the patients,- "to find a lap-dog gone astray, to win the love of a serving girl for a love-lorn swain". All in all this is a roaring farce, full of fun and with the laboratory for the first time used with splendid comic effect. Although the knowledge of astrology clings still to the character of the physician, he is modern in his anatomy; the heart motions are known, the blood circulates, the microscope is in use.

Mention, at least, must be made here of The New Athenian Comedy (1693) by Elkanah Settle. It is a satire on the "Athenian Society," that, with Dunton at its head, promised to answer all

${ }^{63}$ The Anatomist, Act I, sc. 2. 
inquiries sent to it in the pages of its official organ, The Mercury. One section of this periodical was devoted to science and delivered to its readers second hand facts from the Royal Society, such as Swift suggested in his satiric Ode to the Athenian Society. Settle's work purports to be a comedy, but is in fact a "scurrilous dialogue" on the momentous question,-- "Which is the more noble Animal a louse or a flea?" The two scientists, "Jury Squirt, Casuist, and Physician in Ordinary", and "Joachim-Dash, Mathematician", who take part in this debate, have been identified as Mr. Norris and Mr. Sault, respectively. ${ }^{64}$ The ridicule was undoubtedly well deserved.

An adaptation of Moliere's Les Femmes Savantes was made by Thomas Wright in (1693-1697) The Female Virtuosoes. The female wits are to form a society, an "Academy of Beaux Esprits". "Woe then" says Sir Maurice Meanwell, "to the Royal Society; the glory of it will suffer a manifest eclipse". ${ }^{65}$ His wife, Lady Maurice, is the leader of these female wits; she is, in fact, much more of a "virtuosa" than Lady Vaine in Shadwell's Sullen Lovers. Her head is full of "projects". "I was yesterday with my Lord Mayor, to communicate to him a Mathematical Engine of my own, to keep the streets as clean, and as dry as a drawing Room all the year around". ${ }^{66}$ This wonderful invention was to consist of "timber posts" set around the city, to which bellows were to be attached for blowing the clouds away. My Lady, it appears, is a much better philosopher than wife, in the judgment of her husband.

"Sir Maurice,-A pretty thing indeed, to see these long spectacles of yours set on the Top of my House, for you to peep through, and tell how many Hackney-Coaches are going in the moon!"'.

"Sir Maurice,-A pox of Philosopher for a Wife, who the Devil would marry Wit". ${ }^{67}$

But Lady Maurice is not the only projector and observer. Lovewit has a huge limbeck in the process of manufacture-

64 Brown, Frank, Elkanah Settle, p. 98.

- ${ }^{85}$ The Female Virtuosoes, Act II, sc. 1.

Ibid. Act III, sc. 1.

or Ibid. 
"Sir Maurice,-To dissolve the Philosopher's Stone in?

Lovewit,-No, to extract the quintessence of all plays, to sell

by drops to poets of this age". ${ }^{68}$

Catchat has discovered "three men in the Moon fighting a duel in a Church-Yard" ;" she is just now engaged in "teaching a Flea to sing". "The little Creature", says she, "understands notes already; and if I live, she shall sing a song in the next opera that's acted". ${ }^{70}$ Even Witless has caught the scientific fever, for he and his tutor are projecting a "penny-post to the West Indies". ${ }^{71}$ Already he has made an exact and accurate Map, containing the most curious and most remarkable Signs upon the Road between Cambridge and London, with their several Motto's, Inscription and Devices, as they were faithfully taken and delineated by Timothy Witless, Batchelor of Arts, in his Tale of Travels. ${ }^{72}$ And Sir Maggot has his schemes abrewing, for "some virtuosi are to wait on him" about a scheme for the House (Parliament) to have all the Cities, Towns, Villages in England turned into Sea-ports. ${ }^{73}$

The cynic and scoffer of the play is Sir Maurice, who can find no good thing in all of this wit. He makes no claim to having the virtuoso's kind of knowledge; commonsense is still good enough for him. "I am no Scholar, and I thank my Stars for it; but with your leave, so much Commonsense has taught me". ${ }^{74}$ But what more could be expected of a man who would "affront a Teiescope"; one who is made up of a "strange Compound of Vulgar and Clownish Atoms". He embodies commonsense commenting on the "fanatic branches" of the new philosophy.

A worthy representative of the female wits is to be found in the character of Valeria of Mrs. Centlivre's The Basset Table (1706). She has, indeed, gone far beyond all previous "virtuosas" in the matter of experiments; she is "a Daughter run mad after Philosophy". ${ }^{75}$ In her first appearance she dashes upon the stage in the

68 Ibid. Act IV, sc. 2.

or Ibid. Act III, sc. 1.

70 Ibid.

71 Ibid.

72 The Female Virtuosoes, Act II, sc. 2.

Ibid. Act III, sc. 1.

74 Ibid.

${ }^{75}$ The Basset-Table, Act II. 
mad pursuit of "a huge Flesh-Fly", ${ }^{76}$ which she has just received from Mr. Lovely for dissection.

"Lady Reveller,-I àm glad the poor Fly escaped; will you never be weary of these Whimsies?

Valeria,-Whimsies! Natural Philosophy a Whimsey! Oh the unlearned World.

Lady Reveller,-Ridiculous Learning!

Alpiew,-Ridiculous indeed, for Women, Philosophy suits our Sex as Jack-Boots would do.

Lady Reveller,--My Stars! This Girl will be mad, that's certain.

Valeria,-Mad! So Nero banished Philosophers from Rome, and the first Discoverer of the Antipodes was condemned for a heretic.

Lady Reveller,--In my Conscience, Alpiew, this pretty Creature is Spoiled.-Well, Cousin, might I advise, you should bestow your Fortune in founding a College for the study of Philosophy, where none but Women should be admitted". ${ }^{77}$

A bluff sea captain, designed by her whimsical father for Valeria's husband, is announced as just returned from foreign parts.

"Servant,-Madam, here's Sir Richard, and a-

Valeria,-A-What, is it an Accident, a Substance, a Material Being, or a Being of Reason?

Servant,-I don't know what you call a Material Being, it is a Man.

Valeria,-Pshaw, a Man, that's Nothing.

Lady Reveller,--She'll prove by and by, out of Descartes that we are all Machines". ${ }^{78}$

When Valeria is left alone with the Captain, she distracts his wits with her philosophical queries.

"Valeria,-I would have ask'd you, Sir, if you had the curiosity to inspect a Mermaid-Or if you are convinc'd there is a World in every Star-We by our Telescopes, find Seas, Groves, and Plains, and all that; but what they are peopled with, there's the quere.

78 Ibid.

77 Ibid.

${ }^{78}$ The Basset-Table, Act II, sc. 1. 
Captain,-Let your next Contrivance be how to get thither, and then you'll know a world in every star . . . . . Are you always infected?

Valeria,-Dear, dear Philosophy, what immense Pleasures dwell in thee." ${ }^{\prime} 9$

The fish arrives which she has ordered for dissection, and the scene opens upon her laboratory, "where is a table, with books, a microscope, "and the fish lying on it'. Mr. Lovely has found his way here to woo Valeria in her scientific haunts.

"Valeria,-O, Mr. Lovely! Come, come here, look through this glass, and see how the Blood circulates in the Tail of this fish. Lovely,-Wonderful!

Valeria,-I'll shew you a curiosity, the greatest that ever Nature made. (Opens a Box). In opening a Dog the other Day, I found this Worm.

Lovely,-Prodigious! 'Tis the Joint-Worm, which the Learned talk so much of.

Valeria,-Ay, The Lumbricus, Lactus, or Faescius, as Hippocrates calls it, or vulgarly in English, the Tape-Worm . . . . . Oh, the profound secrets of Nature!',80

The bluff sea eaptain was soon "put out of conceit" with Valeria's "philosophic Cant", for, frankly, he did not value "the philosophical Gimcrack" worth a "Cockle-Shell". The father, Sir Richard, in great rage goes to the laboratory just as Lovely is urging Valeria to run away with him, and leave her "dear Microscope". As Sir Richard enters Lovely erawls under a tub that has held the fish.

"Sir Richard,--What, at your Whims,-and Whirligigs, ye Baggage! I'll out at the Window with them.

Valeria,-Oh, dear Father, save my Lumbricus Lactus. Oh, my poor Worm.

Sir Richard,-What is it good for?"

Lovely is of course discovered and his presence explained with comic extravagance. But he is not dismayed. One theory possesses him; if he can humor Valeria's hobby until she will deign

79 Ibid. Act II.

80 Ibid. Act III, sc. 1.

${ }^{81}$ The Basset-Table, Act III, sc. 1 . 
to hear his suit, he believes he ean win her. For him this is not "a mere Speculative Faculty", but for "the Practice". His perseverance is at last rewarded;- "Nay, there's no Philosophy against Love; Solon for that", as even Lady Reveller knew.

"Lovely,-Will not Valeria look upon me? She used to be more kind when we have fish'd for eels in Vinegar"' 82

This is the only instance of a woman working in a laboratory among insects and scientific apparatus. Valeria, however, goes to the full extent; she dissects her pet pigeon to test the "vulgar error" regarding its gall; she "opens a Dog"' to study its internal structure; she examines a fish through the microscope; she is not restrained by an unscientific tenderness or affection. "Can Animals, Insects, or Reptiles be put to a nobler Use than to improve our Knowledge? Cousin, I'll give you this Jewel for your Italian Grey-Hound". ${ }^{83}$ She is familiar with the nomenclature of the Cartesian philosophy; such as, "Accident", "Substance," "Material Being", and "Being of Reason". ${ }^{84}$ She is eager to make inquiry of travellers concerning the marvels in foreign lands. In a word she is thoroughly one of the new scientists, as comic writers knew them.

Mrs. Lovely, in A Bold Stroke for a Wife, (1718) has had four guardians appointed for her, each representing a different humor. Sir Philip Modelove is the fop of fashion; Tradelove is the merchant; Obidiah Prim is the religious fanatic; Periwinkle is the scientist. These four guardians quarrel about the character of the husband that is to be selected for their ward. Each demands that he shall be permitted to select a man dominated with his own humor. The young man, who rashly undertakes to please them all, deceives each in turn into promising to recommend him by impersonating the humors of each. To Periwinkle he is a Colonel, much-travelled, and greatly interested in the curiosities of nature. He has collected many "Rarities", "which are not yet come ashore"; as, an Egyptian Idol, two Tusks of a Hippopotamus, two pairs of Chinese Nut-crackers, one Egyptian Mummy" ${ }^{85}$

82 Ibid. Act $\mathrm{V}$.

$\$$ Ibid. Act II, sc. 1.

84 Ibid.

${ }_{85}^{4}$ Bold Stroke for a Wife, Act II, sc. 1. 
Sir John Tradescant becomes for the time being his uncle. These qualifications captivate Periwinkle; "I say Knowledge makes the Man". He, therefore, gladly recommends the Colonel to Mrs. Lovely; this is the ideal. "He shall be a man famous for Travels, Solidity, and Curiosity-one who has searched into the profundity of Nature. When Heaven shall direct such a one, he shall have my consent, because it may turn to the Benefit of Mankind." "88

"Mrs. Lovely,-The Benefit of Mankind! What, would you anatomize me?

Sir Philip Modelove,-Ay, Ay, Madam, he would dissect you. Tradelove,-or, pore over you with a Microscope, to see how your Blood circulates from the Crown of your Head to the Sole of your Foot." 87

Periwinkle is largely given over to the antiquarian humor. When he is duped into thinking he has inherited $£ 700$ a year, his mind begins to calculate "what a valuable Collection of Rarities" can be bought with it. "I may well reserve sixteen hundred of it for a Collection of such Rarities, as will make my name famous to Posterity".

"With Nature's Works I'll raise my Fame,

That Men till Dooms-Day, may respect my Name". 88

Mrs. Lovely's advice to him is to "study your Country's Good, Mr. Periwinkle, and not her insects-Rid you of your homebred Monsters, before you fetch any from abroad-I dare swear you have Maggots enough in your own Brain to stock all the Virtuoso's in Europe with Butterflies". ${ }^{89}$ And yet he knows other scientific interests also.

"Periwinkle,-Descartes tells us-

Colonel,-Descartes, with the rest of his Brethren both ancient and modern know nothing of the Matter.-You have heard of blazing comets? Those Comets are little Islands, bordering on the Sun". 90

If he has a laboratory it is not mentioned, but he must have a

s8 Ibid.

${ }^{87}$ Ibid. Act V, sc. 1.

${ }^{88}$ Ibid. Act IV.

${ }^{89}$ Tbid. Act III.

${ }^{\circ}$ Ibid. Act III, sc. 1. 
"sacred room" for his rarities. Let him, too, enter the ranks of the new philosophers, even although he is only "a kind of silly Virtuoso". ${ }^{91}$

The character of Carlos in Colley Cibber's Love Makes a Man (1701) is at first a pedantic philosopher. He is fresh from the university and the learning acquired there still obsesses him. His servant, Sancho, says of him,-- "Life, Sir! No prince fares like him; he breaks into his fast with Aristotle, dines with Tully, drinks at Helicon, sups with Seneca; then walks a turn or two in the Milky Way, and after six hours conference with the Stars, sleeps with old Erra Pater". But he is not a scientist; he is a classical scholar who at first is used as a foil to his man-of-the-world brother, Clodio. Carlos, however, quickly lays by all his speculative philosophy for the "Practick", when he falls in love with Angelina. The process of love making a man of him is his escape from pedantry to worldly commonsense; the transformation from a vague, absent-minded scholar to the manhood that prompts him to throttle his brother who has for long bullied him.

The prologue to The Refusal; or, The Ladies Philosophy (1721) characterizes Sophronia as "a Female Philosophic Saint". She proves to be a "she-pedant", not a natural philosopher; she knows the classics, quotes much Latin, but is far from science. She is considered among the experimenters, however, in certain respects. "A handsome Wench, that shuts herself up two or three hours with a young Fellow, only out of Friendship, is making a hopeful Experiment in Natural Philosophy indeed"'. ${ }^{92}$ As a result of this experiment, Sophronia herself says,-- "I am now a Proselyte to that Philosophy which says, Nature makes nought in vain". And to her is given the theme of the play in this rather fine sentence. "In life there's no philosophy like Love". ${ }^{93}$

John Gay's Three Hours after Marriage (1717) has for its hero Fossil, "a physician interested in rarities". Both of these phases of his character enter into the plot. In his character as a physician hits are made upon the practices of doctors. "Your pulse is very high, Madam", says Fossil to his newly-made bride,

91 Ibid. Dramatis Personae.

2 The Refusal, Act III.

2 Ibid. Act V. 
"you sympathize, I perceive".- "What might your Menstruum be", he asks of Plotwell who is disguised as a French Doctor, "Snow-water or May-dew?", Plotwell inquires if there is any secret in "hydrology, zoology, mineralogy, hydraulics, acoustics, pneumatics, logarithmatechny", which he desires to have revealed to him. "That", Fossil answers, "is all out of my way. Do you know any hermaphrodites, monstrous twins, antediluvian shells, bones, and vegetables?" 95

This virtuoso is interested, however, in the "Lapis Lydius, or Touch-stone of Virginity", and prepares to try his household by it. When he has called all of his servants before him, he divides them into two classes, "the Platonicks and the Cartesians". "The Platonicks are for Ideas, the Cartesians for matter and motion". ${ }_{96}$ While Plotwell is in the house in the guise of a French Doctor, Underplot comes in as a patient. A travesty at once follows on the method of diagnosing a case. Plotwell who recognizes his rival proposes the most violent treatment. An operation, he says, is unavoidable; the strongest glisters must be used. The scene when worked to this pitch falls tamely away.

As antiquarian Fossil has a famous museum, filled with his "dear pickled hieroglyphics". Even his new wife is to him "the best of my Curiosities". He decides to lock her up in this room when he leaves to make his calls, thinking she would thus be out of temptation's way. It so happens, however, that Plotwell has been previously carried in as a mummy and Underplot as an alligator. Fossil returns unexpectedly, with two of his friends, Drs. Nautilus and Possum. They are desirous of examining the two newly received curiosities much to the consternation of Mrs. Townley and the two intriguers. Mrs. Townley suddenly looks through the telescope that stands conveniently near and cries,-_."What do I see! Most prodigious! A Star as broad as the Moon in Daytime!", The three virtuosi rush to the instrument and quarrel as to which one shall first observe the phenomenon. Meanwhile

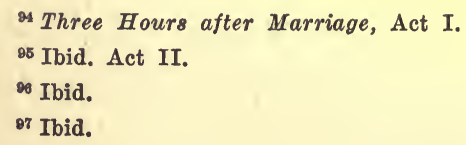


the opportunity comes for Plotwell and Underplot to escape. The scene is pretty well done.

This phase of Fossil's character is most thoroughly treated. "The Museum of the Curious", he says, "is a lasting Ornament. And I think it no degradation to a dead person of quality, to bear the rank of an anatomy in the learned World". ${ }^{98}$ Dr. Nautilus thinks the finest decorations for the "closets of Ladies" would be "preserved Butterflies, and beautiful Shells, instead of ChinaJars, and absurd Indian pictures." "99 "Ah, Dr. Nautilus", says Fossil, "how I have languished for your feather of Phorphyrion! - the dust of Manchora, the antediluvian Trowel, the fragment of Seth's Pillar, and the Entire Leaf of Noah's Journal".100 Mrs. Townley declares,- "A Mummy is his intimate Friend". The variety of Fossil's collection is astonishing. When Mrs. Townley finds two of her lovers in the museum, she turns to the other rarities with,-_ "I don't know but I may have twenty lovers in this collection. You Snakes, Sharks, Monkeys, and Man-Tygers, speak, and put in your claim before it is too late". ${ }^{101}$ The strange sailor finds his way to Fossil's house by the fame it has in the community for containing "the raree-show of oyster-shells and pebble-stones". So it be a rarity, it mattered not of what, there was a place for it in his museum.

Once more the "fanatic branches" of science do not escape. That strange theory regarding tarantulas is here.-Fossil,-- "Newmarried men are treated like those bit by the Tarantula, both must have music". ${ }^{102}$ Alchemy, too, finds expression here,-

"Plotwell,-Me make dat gold my own self of de lead of the great Church of Cracow.

Fossil,-By what operations?

Plotwell,-By calcination, reverberation, precipitation, sublimation, amalgamation, volatilization." ${ }_{103}$

Here again the old and the new science are confused. There

98 Three Hours after Marriage, Act III.

99 Ibid.

100 Ibid.

101 Ibid.

102 Ibid. Act I, sc. 1.

108 Ibid. Act II. 
seems to be no attempt to distinguish between the obsolete, "pretended sciences" and the new philosophy.

Fossil stands as a late comic representative of the scientific humor. He shows no progress over his predecessors; indeed, much of his scientific knowledge had appeared several times before him, and was certainly common property in the days of Sir Nicholas Gimcrack. There is nothing new in what he has to offer; even the "virtuosa", Valeria, could teach him experiments. But here he is as one "who never opposes a luciferous experiment; it is the beaten highway to truth", - at the time when Merital, in Fielding's Love in Several Masques (1728), could say,--"In town we look on none to be so great a fool as a philosopher, and there is no fool so out of fashion". ${ }^{104}$

James Miller wrote a comedy in 1726, called The Humours of Oxford. The chief humor, as might be expected, is pedantry, and the chief exponent is Lady Science, whom Clarinda, her niece, calls "Lady Gimerack". ${ }^{105}$ She is, indeed, wholly possessed with this pedantic scientific humor; every thought finds expression in scientific terms. "I might as easily make the most erratick Comet describe a regular circle, as reduce you within the Sphere of Understanding", ${ }^{108}$ she says to Clarinda. "I can't bear much malignant Defamation; but leave you as an Ignoramus of the first Magnitude", she cries is exasperation. "There is not an individual Angle in the whole Solid of my Body, but quakes when I come near her"'.107 When she discovers that she has mistaken Gainlove in disguise for Victoria's learned husband-to-be, she exclaims,-- "I am in an universal Fermentation at the thoughts of it-every Nerve and Fibre in my Frame is put into Vibration with the Fright." 108

Lady Science demands that the man she has chosen for her sonin-law shall answer certain interrogatories;-

"Lady Science,-In the first place, Sir-which Hypothesis are you of-the Ptolmaick, or Copernican?

${ }^{104}$ Love in Several Masques, Act I, sc. 1.

105 The Humours of Oxford, Act I, sc. 1.

100 Ibid.

107 Ibid. Act II, sc. 1.

108 Ibid. Act IV, sc. 2. 
Gainlove,-Which System? Why, the-the-

Lady Science,-The Copernican I suppose you mean.

Gainlove,-The Copernican.

Lady Science,-For the other is egregiously repugnant to Reason, and the usual Operations of Nature-But pray, Sir, have you any skill in Judicial Astrology-I think it absolutely necessary for one who has a Family, to be a considerable Proficient in that useful Science.

Gainlove,-Absolutely.

Lady Science,-Then without question you can erect Schemes, and calculate Nativities, Sir-You are acquainted with the Conjunctions and Oppositions of the Planets, their Houses and Signs-There is the Bull, the Bear, the Ram, the CrabGainlove,-Ay, Madam,-and the Crocodile, the Elephant, the Whale-

Lady Science,--Well, Sir, I have but one thing more to ask you, and you shall be conducted to your Bride-Do you think it ever possible to find out the Longitude, Sir?-it is such a vast Profundity, that I fear 'tis beyond the reach of any Man to fathom it.

Gainlove,-A vast Profundity.

Lady Science,-A Man of abundance of Learning! he still saith as I do". ${ }^{109}$

So far has this virtuoso gone into the toils of the scientific humor, that she applies the test even in matrimony.

Nearly all the varied interests of the new philosophers are represented here. Lady Science no longer doubts the existence of a vacuum, "for the Skulls of the young Girls and Fops of this Age, are Demonstrations sufficient." 110 She knows all the systems of philosophy from Socrates to Whiston; she discourses on Astronomy and Philosophy in eurtain lectures. ${ }^{111}$ The scope of her interest has extended to every scientific apparatus. When she repents of her philosophical humor she declares;- "I will destroy all my Globes, Quadrants, Spheres, Prisms, Microscopes, and Magick-Lanthorns-I'll throw out all my Lumber of Load-Stones, Pebbles, and Petrified Shells, to pave my Door-I'll convert my Air-Pumps into

${ }^{109}$ The Humours of Oxford, Act IV, sc. 2.

110 Ibid. Act I, sc. 1.

111 Ibid. 
Water-pumps, send all my Serpent's Teeth, Mummy's Bones, and Monstrous Births, to the Oxford Museum; for the entertainment of other as ridiculous Fools as myself". ${ }^{112}$ This ambitious philosopher, also, has taken the whole realm of knowledge to be her province.

But, with all her pretense to learning and college manners, she is despised by all the other characters. Her daughter and her niece mock her; Haughty deceives her; Ape-All derides her. "You know what a Pretender the old Lady is to learning and Philosophy","113 says Gainlove, even while he prepares to woo her. The "College Manners" so highly recommended by Lady Science to her niece, "like your College Learning are a Hodge Podge of Contradictions to every Thing in Practice, and only fit for the Place where they are taught". ${ }^{114}$ Like Sir Nicholas Gimcrack, she reforms at the end of the play. "I am justly made a Fool of, for aiming to be a Philosopher-I ought to suffer, like Phaeton, for affecting to move in a Sphere that did not belong to me". ${ }^{115}$

The special point to this comic satire is the pursuit of the new philosophy by women. The play-writer, however, has been carried so far beyond this end as to satirize all the university interests. There is not a single character who has come to college for serious endeavor. Young Ape-All thinks he has wasted two years of life because he followed his tutor's advice and studied Latin and Greek; Connundrum is a veritable travesty on all pretense to scholarship; Haughty is a rascal and a fraud. But there is an element of serious criticism in the speech given to Gainlove at the close of the play. "Wh", People of either Sex, Madam, are generally imposed on, when they concern themselves with what is properly the Business of the other. The Dressing-Room, not the Study, is the Lady's Province - and a Woman makes as ridiculous a Figure, poring over Globes, or through a Telescope, as a Man would with a pair of Preservers mending Lace". Philosophy may "fit men as Jack-Boots do"; but it is no business for women.

A very stupid comedy was published anonymously in 1742 , en-

112 Ibid. Act V, sc. 1 .

113 Ibid. Act I, sc. 1.

114 Ibid. Act II, sc. 1.

118 The Humours of Oxford, Act V, sc. 1. 
titled The State of Physick, which may be found in a volume of Comedies not Acted, that was edited by John Genest. Across the title page of this comedy in the copy that fell into the hands of the writer was written in a bold script the name, "Thos. Dickinson", but whether intended for the author or not is unknown. "This piece was never acted", says the Biographia Dramatica, "nor do we know who is the author; yet we conjecture it must have been some person of the faculty, since, if we may be allowed a paltry quibble, it is apparent, that even in the very title page, to make use of a vulgar phrase, He talks like an apothecary". ${ }^{118}$ But, whoever the author was, he made his purpose plain enough; namely, to expose medical quackery and the greed of apothecaries.

This study is concerned only with the three doctors, Mody, Runabout, and Easy. Mody is "A Physician of note, formal, and pretending to Learning'. $\mathrm{He}$ is in daily attendance upon Lady Humane and by his learned conversation keeps her bewildered into a constant fermentation. Connected with the waiting room of his office is his museum, with many shelves apparently filled with books. On inspection, however, Lord Humane finds them for the most part painted blocks of wood.

"Mody,-The Vacuities are embellish'd.-A shelf half filled has such a mean look, that your lordship will judge the improvement not despicable-

Runabout,-Nothing but the Fertility of your Cranium, Doctor, could have produced, and nothing but the Royal Society can merit so serviceable a production.

Mody,-It shall be communicated, to be through them, made public, for the general good." 117

This character is a replica of Dr. Fossil, with his rarities, his "fossils, shells, and butterflies". From his tongue flow glibly the cant phrases of medical quackery. When Goody, the apothecary, fails to include among some half dozen other ingredients a single powder, Mody exclaims,- " 'Twas the Vehicle of all you took: 'Tis the Alcahest of the Chymists, Primum Mobile of the philosophers, and Aqua Vitae of the Apothecaries". ${ }^{118}$ Later, when he

116 Biog. Dram. IV, p. 299-300.

117 The State of Physick, Act III, sc. 3.

118 Tbid. Act I, sc. 2. 
and his parasite, Runabout, are alone, he confesses,-_"But I did my Endeavor to soothe her up with the usual jargon contrived for the Amusement of her sex". ${ }^{119}$

Mody and Runabout, with all their pretense to learning have never taken a course at the College. Their knowledge has been gained in London, "The great English University". They have as associates rogues of other professions of as deep a dye as themselves. Mody has arranged for a dinner to which he has invited Orator Puff, Counsellor Certiorari, Alderman Commerce, and Dr. Gimcrack. And these raseals with their brazen affrontery are successful in deceiving their patients until Dr. Easy appears. He is, in fact, a thoroughgoing sentimental hero in his relationship with Miss Worthy; as a physician, he represents the first comic character who is deserving of respect. He makes no unfounded claims to knowledge; he charges no exhorbitant fees; he relies more upon commonsense than upon the nostrums from the apothecaries' shops. This quiet, modest man rescues Lady Humane from the clutches of Mody and Runabout, exposes them as rogues, and wins the heart of Miss Worthy. It is a matter for astonishment to one who has followed the comic type of physicians through this period to hear him speak as follows; -

"Lord Humane,-Who tells you, Nature is so potent as you make her?

Dr. Easy,-The great Hyppocrates, together with that modern Ape of his, good Sydenham. Men, my Lord,-

Who by discarding Hypothetic Rules,

With all the heavy Jargon of the Schools;

Observing Nature, Patriots in her Cause!

And being upright gain'd themselves applause!"120

This comedy, with all its dullness, is noteworthy for two reasons. It gives, in the first place, a clear, satiric exposition of the collusion between dishonest physicians and apothecaries. The very same knavery that aroused the ire of Samuel Garth in the Dispensary (1699) was still extant. This was proper material for satire and thoroughly deserved the lashing it received. In the second place, there is shown the first worthy doctor, who represents the earliest

119 Ibid.

120 The State of Physick, Act IV, sc. 4. 
evidence that this profession was attaining respect. Both the good and the bad physicians lay claim to the new science, but here the true representative is successful.

This is the last representation of the new science in comedy so far as this investigation has gone. There remain the casual references to the new interest and activity, which can at best be only indicated. Such allusions will naturally be found for the most part as figures of speech. Chemistry has furnished many; (Bellamour) "A little of thy Chemistry, Tom, may extract gold from that dirt"..21 (Malwit) "Thy Chemistry has from that one Virtue extracted all the rest". ${ }^{122}$ (Setter) "Sublimate, if you please, Sir, I think my achievements deserve the epithet". ${ }^{123}$ (Camillo) "Tis the very quintessence and extract of it. (Vidette) I do not like your Chemical preparations of love". ${ }^{124}$ Astronomy is likewise a familiar source of allusion. (Angelica) "What a bustle did you keep against the last invisible eclipse".125 (Cynthia) "You have looked through the wrong end of the perspective". ${ }^{126}$ (Lady Frothwell) "Well, I swear, Mr. Brisk, you understand astronomy like an old Egyptian. (Brisk) Not comparable to your Ladyship; you are the very Cynthia of the skies, and queen of stars. (Lady Frothwell) That's because I have no light but what's by reflection from you, who are the sun. (Brisk) You have eclipsed me quite". Nondescript references occur, usually as compliments; (Lord Formal) "Your Ladyship's eyes are two loadstones that attract the admiration of our whole sex". ${ }^{127}$ (Young Pedant) "Logick is in learning, what the compass is in navigation. It is the guide by which our reason steers in the pursuit of true philosophy"..128 (Valentine) "She is harder to be understood than a piece of Egyptian antiquity or an Irish manuscript". (Sir Paul Plyant) "I am provoked into a fermentation". (Bellamore) "A Fool is a vacuum in $\mathrm{Na}$ -

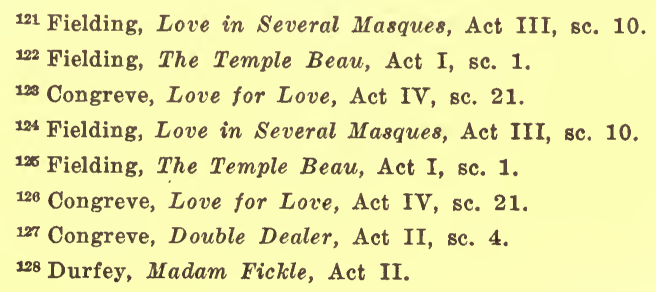


ture." These are some of the chance fragments blown about by the wind of literary allusion. They reveal merely the extent to which scientific activities had entered into the familiar thought of literary men. Presumably they would be understood by the readers or hearers without footnotes, such as Shadwell found necessary in The Lancashire Witches. Gradually the new scientific ideas were making their way into the minds of men, but outworn beliefs were still "pensioned in dotage" for literary purposes.

This study of the representation of new science in comedy has revealed a fact, which might have been deduced $a$ priori, that the same material has been used over and over again. The writers of comedy would not be expected to become thorough students of science; if they had, their satire would doubtless not have been written, for then they would have understood more clearly the splendid work that was being done and they would have appreciated more fully the sterling character of the leaders in scientific thought. If, then, their knowledge was not deep, it might be expected that they would use the most obvious sources. What are they?

It has been shown that the Royal Society was the centre of scientific interest in England. Everyone seemed to understand the references to Gresham College where this society had its beginning and where it continued for many years. Its official organ was the Philosophical Transactions, which was put on sale at many of the bookshops in London. Here, then, was one obvious source of knowledge for the wits. It was to this source that Thomas Shadwell went for almost all of his material, practically all of his allusions and a good part of his phraseology may be traced to the reports of experiments in the Transactions, just preceding the presentation of his comedy, The Virtuoso. For example, on respiration, see Swammerdam's letter Oct. 26, 1667, and the experiment of Robert Hooke, Oct. 24, 1667; on the transfusion of blood, see the report for May 6,1667 , and the experiment of Drs. Lower and King at the Arundel House, Nov. 16, 1666, for spiders, a discussion by I. Wray,"On Spiders"-1668, for tarantulas, review of S. W. Senguerdius's "de tarantula," 1668, Phil. Trans. vol. III, p. 660 ; on eels in vinegar, see the letter from Leeuwenhoek, dated Delft, April 21, 1676; 
on glow-worms, see the report of Robert Boyle, February 15, 1672; on speaking trumpets, see Phil. Trans. Jan. 27, 1672, a report by Sir Samuel Moreland. It would seem, therefore, that Shadwell had access to certain volumes of the Philosophical Transactions and had "crammed up" for his comedy. As soon as it appeared, the comedy itself would become a new and more easily accessible secondary source for Shadwell's successors, just as the scientific facts were warmed over and served diluted in the columns of the Athenian Mercury.

A second source of material was the books that were being written by the virtuosi. Sir Nicholas Gimcrack's wild claims of being able to fly had its origin in a book by Dr. Wilkins, The Discoverer of a New World; Or, a Discourse Tending to Prove that 'tis Probable there may be another Habitable World in the Moon, 1638. To this was appended, says Anthony a Wood, a Discourse Concerning the Possibility of a Passage to the World in the Moon. ${ }^{132}$ Watts attached to this note of Wood's the following,-- "When at Wadham College he (Wilkins) attempted to make the art of flying practicable". Lord Worcester kept the idea alive by including in his Century of Inventions (1655) this statement (77),- "How to make a Man to Fly; which I have tried with a little Boy of ten years old in a Barn, from one end to the other, on a Hay-Mow". ${ }^{133}$ Ten years later Robert Hooke wrote,- " "The way of flying in the air seems principally impracticable, by reason of the want of strength in humane Muscles; if therefore that could be supplied, it were, I think, easier to make twenty contrivances to perform the office of wings'". ${ }^{134}$

When Valeria, in her eager search for truth, sacrificed her pet pigeon on the altar of science in order to discover whether the popular tradition that a pigeon and a dove have no gall was true or false, she was taught so to do by Sir Thomas Browne's Vulgar Errors. He records that he tried the same experiment. ${ }^{135}$ His surgical practice may have given him greater skill in dissection, for

132 Wood, Anthony a, Athen. Oxon. vol. III, col. 969.

${ }^{133}$ See also Milton's History of Britain, 1670, on Elmer, a Monk of Malmesbury, Kennet's History of England, vol. I, 1706, Friar Bacon's Miracles of Art, Nature, etc., 1659.

134 Hooke, Robert, Micrographia, Preface, p. 19.

196 Browne, Sir Thomas, Vulgar Errors, vol. I, p. 317. 
he found the tradition false while Valeria thinks it is true. To Sydenham's Book of Fevers and a Discourse on Fermentation (by W. Sympson, 1675) was due the popular "fermentation" idea. Ray's book of travels was an inexhaustible fountain for the comic spirit. ${ }^{136}$

Another source of material was the popular lectures on the new science. Yearly there was a free course of lectures given in London on the Boyle Foundation, beginning early in the 90 's. The ablest scientists were called to this service, and large crowds of people assembled to hear them. At these lectures experiments were performed, at least on occasion, for Desaguliers, a popularizer of science during the first half of the eighteenth century, developed his Royal Lectures into a book of two volumes, entitled $A$ Course of Experimental Philosophy, 1744. This scientist also gave private popular lectures year by year in the city, as did others. ${ }^{137}$

A fourth source of material was rumor. The sensational experiments, such as the transfusion of blood from a sheep into a man, would spread by report through the city. According to Pepys, there was a long discussion over the advisability of inviting the Duchess of Newcastle to attend a meeting of the Royal Society lest the town should be full of ballads on the event. ${ }^{138}$ If such a simple incident would be noised abroad, how much more a sensational experiment.

Another method by which scientific activity became known was the return of students from the university. The "pert young Soph" would not only boast of his knowledge of "violent Motions", of "Atoms and Globuli", ${ }^{139}$ but would also report whatever was sensational. The physicians, for instance, had difficulty in keeping their dissections private; wild stories were spread abroad as to the source of the bodies and the manner of dissecting them. A burlesque on such practices is contained in F. Coventry's Pompey The Little, 1750.

The collecting of "rarities" had become such a fad by the early years of the eighteenth century that no dramatist needed to want

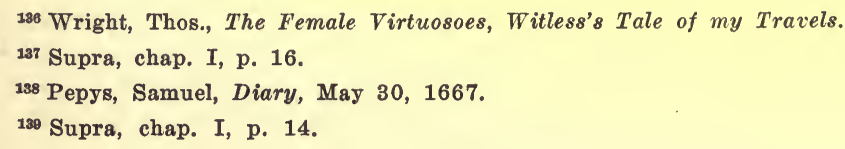


for material. John Tradescant of Lambeth was the great leader of the new interest in the seventeenth century, from whose efforts the Ashmolean Museum was first stocked. But countless others were "infected". The older seventeenth antiquarians were Burton, Browne, Walton; the later ones were Llwyd, Plot, Ralph Thoresby, Elias Ashmole. In the eighteenth century all the physicians who pretended to social distinction had their collections $;^{140}$ and gentlemen and ladies of leisure sought for curiosities, coins, manuscripts, old and rare copies of books, "pickled hieroglyphics", and whatever rust had corrupted and age had dimmed. Such gentlemen of distinction as Lord Montague and Lord Winchilsea were much interested in antiquarian researches in England and elsewhere. The interest lived on through the Whartons, Gray, and Horace Walpole, and has not yet passed away. Besides, before the end of the seventeenth century coffee-houses were advertising collections of "rarities". ${ }^{141}$ There was, also, the work of such scientific classificationists as Ray, Morison, Willoughby, Grew, Malpighi, and Woodward. ${ }^{142 a}$ To the lay mind these men, too, were hunting curiosities. Everywhere there was material ready at hand for the writers of comedy.

The men and women who professed a dominating interest in science were, in the seventeenth century comic parlance, fools, one and all; that is, they were possessed by a humor. "No Phantastick", says Bruce of Sir Nicholas, "that has lost his Wits in Revelation, is so mad as this Fool". "You are mistaken", Longvil answers, "this is but a faint Copy to some Originals of the Tribe". ${ }^{142 b}$ Valeria is a "Daughter run mad after Philosophy"; Periwinkle has "maggots enough in his own brain to stock all the virtuosoes in Europe with butterflies" ; Lady Maurice is "possessed"; Crispin believes that, unless "the world belies 'em, there are many physicians just as great fools as myself"; Mopus is following "Quixotism in Philosophy"; Gainlove thinks "there is no great Difference between a Philosopher and a Lover only the first is the more reasonable

140 Besant, Walter, London in the 18th Cent., Medicine.

141 Supra, chap. I, p. 18.

142a Woodward, Physician and Antiquarian, was satirized by the triumvirate, Gay, Pope, Arbuthnot, in Three Hours After Marriage. Cf. also the farce Harlequin Hydaspes; or, The Greshamite, 1722.

142b The Virtuoso, Act V. 
Madness of the two". And yet to be a "fool" with Boyle and Newton is better than to be witty-with some dramatists.

Fools are pretenders. The knowledge which the scientists profess in comedy is all bluff; if it be a virtue, they have it not. Sir Nicholas, when face to face with the mob, confesses he never did anything of use; Valeria deserts her "dear, dear Philosophy" for the arms of her lover; Veterano, for all his study of "rarities", is easily fooled with some "modern antiques"; Dr. Boliardo, after" years of observing the moon, is deceived into thinking he sees a nymph up there when Scaramouch holds a picture before the telescope; Fossil can not distinguish between a real mummy or a real alligator and men dressed in costumes from the theatre. Mopus finds "terms" (learned language) to be three-fourths the physician's knowledge; Drench and Gregory become doctors without a course in medicine; Lady Science is "a great Pretender to Philosophy". None of these "inferior members of the tribe" have the learning which they profess.

But, even although they did have the knewledge, says comedy, it would be of no use. Here is the essential criticism in all of this satiric representation of science. "This foolish Virtuoso does not consider that one Bricklayer is worth forty Philosophers". ${ }^{143}$ "So it is Knowledge, 'tis no matter of what", ${ }^{144}$ says Longvil of Sir Nicholas. "And yet, by your favor, Sir, of what use can they be", ${ }^{145}$ Pedro inquires of Veterano, the Antiquary. The greatest virtuoso of them all had not "invented even so much as an Engyne to pare Cheese with". ${ }^{146}$ The study of antiquities only wasted good money; the study of insects and fishes and all the phenomena of nature merely cracked the brains, spoiled women for wives, ${ }^{147}$ men for husbands, ${ }^{148}$ made girls foolish, ${ }^{149}$ boys pedantic. ${ }^{150}$ Such knowledge might be a very fine thing; but "there's no Philosophy like Love", there is no science equal to commonsense. Therefore, Sir

143 The Virtuoso, Act IV, Bruce.

144 Ibid. Act III.

145 The Antiquary, Act II.

146 The Virtuoso, Act V.

${ }^{147}$ The Female Virtuosoes, Sir Maurice,- "Who would marry Wit".

148 The Cheats, Mrs. Mopus,- "I wonder what I'm better for a husband in you. Here you sit moping and moping all day upon a book," Act I, sc. 3.

$149 \mathrm{Cf}$. Valeria and Sophronia.

150 Cf. Carlos. 
Nicholas repents; Dr. Boliardo sees "there is nothing in this Philosophy"; Carlos is "made a man" out of a pedant by discarding learning; Valeria flings away Philosophy for a lover; Sophronia finds "there's no Philosophy against Love,-Solon for that". Here are good demonstrative reasons why philosophy is worthless. Once these men and women were blinded with this scientific humor. but now they see with the eyes of commonsense.

"So I think these excellent men do highly deserve Commendation for these seemingly useless labours, and the more, since they run the hazard of being laughed at by Men of Wit and Satyr, who always have their End, if they make their Readers Sport, whether the thing which they expose deserves to be ridiculed or not":151 Wotton has here expressed accurately the attitude of the writers of comedy who "exposed" the scientific humor. There is no discrimination between the good and the bad, between true worth and pretense. A part of this attitude was due to the spirit of the age which was to "expose" everything that was exposable; the wits were no respecters of persons. Another part was due to the general lack of understanding of what was actually being done. Such opponents of the Royal Society as Dr. Henry Stubbe would not hesitate to create the wrong impression of the scientific work, if only they could make their point. Hobbes expended a vast deal of energy combating his "man of straw". The very fact that Sprat and Boyle and Glanvil and Wotton took pains to explain at great length the nature and possible value of the Royal Society's work shows a wide-spread misunderstanding. "I observe the incompetency of their Judgments, who are enemies to the Real Experimental Philosophy, in that they do not (as I intimated) at all, or very little, understand what they condemn. This I have some reason to say, since in the whole compass of my Acquaintances, which is not very narrow, I profess I know not one who opposeth the Modern Way, that is not almost totally unacquainted with it'". ${ }^{152}$

A third part of the attitude grew out of a wilful and conscious misrepresentation of facts. Shadwell deliberately garbled his quotations from the Philosophical Transactions. Sir Nicholas's dis-

151 Wotton, William, Reflections, etc. pp. 274-5.

${ }^{152}$ Glanvil, Joseph, Essay III, p. 53 and Glanvil, Joseph, Essay III, pp. 274-5. 
courses on ants, for example, was taken from a report by Dr. King, March 11, 1666, "Concerning Emmets or Ants, their Eggs, Production, Progress, Coming to Maturity, Use, etc." ${ }^{153}$ This is a case of malicious misrepresentation. The experiments are puerile enough to be sure, but the effort is an honest one; the truth, whether worth knowing or not, is sincerely sought. By Shadwell's own definition this is not a legitimate field for his satire; for here is no affectation, no presumption. Or, again, he consciously misrepresented facts in his satire on "eels in vinegar", which appears in The Virtuoso and was copied from it in The Basset-Table. The source of this material is a letter to the Secretary of the Royal Society by Leeuwenhoek from Delft, April 21, 1676. ${ }^{154}$ This scientist had been making some microscopical experiments with "wine of last year's growth". "In this wine, I have divers times observed small living Creatures, shaped like Eels", etc. "Eels in vinegar" are ridiculous enough, but the discovery of microbes (bacilli) is a great and serious scientific event. Or, finally, there is a culpable vilification in the satire on the transfusion of blood, which was in fact a seven days' wonder in London. ${ }^{155}$ This operation was tried many times in England as well as in France and Italy. The first case reported to the Royal Society was June 20, 1665,-a transfusion between two dogs. During the month of July, 1667, news reached London of two operations performed in Paris, in which the blood was transfused from a sheep into a maniac. Several members of the Society being therefore eager to try it for themselves, a committee waited on Dr. Allen, Physician to the Hospital (Bedlam) to ask for a "victim". "The truth on it is, we shall never get any but Mad-men for that operation". ${ }^{156}$ The request was not granted, but in November, 1667, the experiment was really performed at the Arundel House where the Society was then meeting. Arthur Coga, a poor student, offered himself a willing sacrifice for a guinea. Pepys says the fellow was "phantastic", and Dr. King writes of him,-_"He spoke Latin well, but that his Brain was sometimes a little warm". About twelve ounces of

158 Phil. Trans. Mar. 11, 1666.

164 Ibid. April 21, 1676.

155 Cf. Phil. Trans.

156 The Virtuoso, Act IV, Sir Nicholas Gimcrack. 
blood was transfused with success and reported benefit. The operation was repeated December 12th of the same year, again with success. At once the imagination began to picture the most wonderful possibilities, according to the writers of comedy. The words of Oldenburg, however, are words of sober sense and express more clearly the conservative attitude of the scientists. "It seems not irrational to guess aforehand, that the exchange of Blood will not alter the Nature or Disposition of Animals, upon which it shall be practiced; though it may be thought worth while for the satisfaction and certainty to determine that point by Experiments". ${ }^{157}$ "The most probable Use of this Experiment may be conjectured to be that one Animal may live with the Blood of another'. ${ }^{158}$ Modern science has proved this to be true. Thus were facts transformed in the Great Alembic of satire.

As the physicians in the eighteenth century were distinguished by their "full-bottomed wigs, cloudy-headed canes, and sober demeanor," so the scientist was known by his "learned language",in comedies. Sir Nicholas's "emittent and recipient", "humid element", "superficies", cacochymious", Valeria's pedantic Accident, Substance, Lumbricus Laetus, Fossils, Lapis Lydius, were assumed to be the general learned style of speech and writing. The representation is manifestly unfair. Bishop Sprat has stated the ideal of scientific writing fully, ${ }^{159}$ and followed it himself. Boyle has a clear, unaffected style; Glanvil and Hooke wrote in a terse, compact, direct manner, far on the road toward Addison. The generality of scientists could write and did write, simply and unaffectedly. "The virtues of scientific writing spread ..... and wrought with the instinct of conversation and social amenity, and with the love of argument and pleading and oratory, to form modern style." ${ }_{160}$ Though the terms in comedy are the real terms of science, the style is the style of the rhetorician, not the scientist.

Not all scientific material was suited for comedy. The wits.

${ }^{157}$ Phil. Trans. Dec. 17, 1666, p. 357.

158 Ibid. p. 358.

159 Sprat, Thomas, History of the Royal Society, "And to accomplish this they have endeavor'd to separate Knowledge of Nature from the Colours of Rhetoric, the Deceits of Fancy, or the Deceits of Fables," p. 62. "Preferring the language of Artizans, Countrymen, and Merchants, before that of Wits and Scholars." p. 113.

160 Elton, Oliver, The Augustan Ages, p. 420. 
knew this and selected with some care the more sensational experiments. By thus emphasizing and exaggerating the startling things all scientific endeavors were made ridiculous. If there had not been a substantial basis of commonsense for the new philosophy, if it had not really been largely established upon "the two great pillars of truth, Reason and Experience", it would have been laughed away, as Cervantes served chivalry.

When a general survey is taken of this form of literary expression for the new science, a sense of disappointment is felt. Among all these "Wits and Railleurs" there is a lack of appreciation of both men and achievements. There is not a single character in the comedies worthy of respect so long as it is dominated by the scientific humor, not one but bears the contempt, justly earned, of all his friends, with the single exception of the sentimental hero, Dr. Easy, in The State of Physick. The man of science, as the play-writers presented him, is despicable because he is a "fool", engaged in the vain pursuit of useless knowledge, a pedant, a pretender to learning, wholly absorbed in an interest outside the social realm of London society folk. He is never wholly relieved from the taint of pseudo-science, but he is no longer a "vague, peevish pedant, much occupied with physiognomies, dreams, and fanatic ideas as to the properties and powers of various substances". ${ }^{161}$ This was the old student of occult science, not the Baconian philosopher. The worst fault of the new scientist was to devote his time and money to the investigation of insects and to the collection of rarities; he did not study his "country's good but her insects."

The actual achievement in science was not appreciated by the play-writers. In comedy the scientist frittered away his time in gazing at the moon, in poring over insects, or in useless speculation; he never invented anything so useful as a mouse-trap or an engine to pare cheese with; he collected curiosities only to have a house built for them; he sought knowledge for its own sake. In reality, the scientist discovered the law of gravitation and founded modern botany, geology and physiology; he invented the air-pump, the thermometer, the barometer, the steam-engine; he prepared the way for the later writing of history and saved many a manu101 Shipley, A. E., Cambridge History of English Literature, VIII, 419. 
script which the world would not now willingly let perish. A bricklayer was worth forty philosophers of comedy; and yet the period produced some immortal names. One is led to guess shrewdly that the superficiality of the scientist in comedy is due largely to the superficial knowledge on the part of the play-writers. To them it was a humor and nothing more. 


\section{CHAPTER IV}

\section{The New Science and Poetry}

The new science was but a minor interest in a complex, unsettled period and was forced to compete with politics, society, and religion for popular attention. It is true, that, where the conflict between "ancient faith" and new philosophy was sharpest, where commonsense and reason met in mortal combat with witchcraft, astrology, and inherited beliefs, science came into due prominence. It was like the breaking of a wave upon a rugged shoreline, the force of the onward movement being revealed by obstruction. But, necessarily, to the vast majority of men the new interest was a thing apart from the real life of London, merely a voice faint in the distance, and the new ideas were incidental. For the group of men comprising the Royal Society was never large, the active investigators never numbering above a dozen, and they had avowedly sought refuge in study from the turmoil and publicity of the times.

The work of the new philosophers, however, while not set on a candlestick, was not hidden under a bushel. Some knowledge of their observations and experiments made its way into the popular mind through publications, popular lectures, the universities, and rumor. "The town was filled with ballads", it must be remembered, upon the visit of the Duchess of Newcastle to a meeting of the Royal Society. ${ }^{1}$ The virtuosi appeared frequently upon the stage in comedies; Sir Nicholas Gimcrack gave his name to scientific apparatus and "rarities" as early as 1676. One may assume that practically all educated men in London and vicinity knew something of the new science. It could not fail, therefore, to receive some manner of representation by the poets of the period, aside from those who were brought into intimate contact with it. A discussion of this literary expression falls naturally into three parts: (1) The exploitation of the new interest by the satirists, (2) the appreciation which the new philosophy found among the men of poetic imagination, and (3) the contribution of "imaginations and similitudes" to poetic imagery.

1 Pepys's Diary, May 30, 1667. 
The satirists of the period, the "Wits and Railleurs", represent in general one kind of attitude and may, therefore, be classed together. Their avowed purpose was to unmask pretense; they professed to wage war against vice. "Sincere or not, satire is essentially a kind of writing which pretends to unmask pretense". ${ }^{2}$ Joseph Hall, the father of this kind of verse in England, wrote,-

"The satire should be like the porcupine

That shoots sharp quilles out in each angry line, And wounds the blushing cheek and fiery eye Of him that hears, and readeth guiltily.

Meanwhile, sufficeth me, the world may say

That I these vices loath'd another day.", 3

Andrew Marvell eloquently declared that "when the sword glitters over the judge's head and the churchmen are silenced through fear, then is the poet's time, 'tis then he draws and single fights forsaken virtues cause." "Satire," wrote Dryden, "is a kind of poetry ..... invented for the purging of our mind; in which human vices, ignorance, and errors, and all things hesides, which are produced from them in every man are severely reprehended".5 Swift said, "There are two ends that men propose in writing satire, one . . . p private satisfaction and pleasure of the writer . . . . the other . . . . a public spirit prompting men of genius and virtue to mend the world as far as they are able". ${ }^{8}$ The great master of satiric verse, Pope, added,"And indeed there is not in the world a greater error, than that which Fools are so apt to fall into, and Knaves with good reason to encourage, the mistaking a satirist for a Libeller; whereas to a true Satirist nothing is so odious as a Libeller, for the same reason as to a man truly virtuous nothing is so hateful as a Hypocrite." The purpose of satire, thus expounded, seems worthy and justifiable. No man need be ashamed to fight for virtue and truth against vice and error.

2 Wendell, Barrett, The Temper of the 17th Century Lit. p. 336.

Ball, Joseph, Bk. $\nabla$, Sat. III.

4 Marvell, Andrew, Tom May's Death, 11, 63-66.

5 Dryden, John, Essay on Satire.

- Intelligencer III.

'Pope, Alexander, Satire and Epistles of Horace, Advertisement. 
This high satiric ideal, however, was not always followed. Too many writers of verse found "the easiest way to be witty is to be cynical" ; others were "goaded into inspiration" by malice or personal grudge; others, still, followed the fashion set by their betters and railed indiscriminately against the world; too few sought with fairness and candor to discover truth and laugh follies away. Satiric verse, like the satiric comedy, exploited the humors of men. Weaknesses were exaggerated; foibles were magnified; characters were defamed. To the satirists men were either "Fools" or "Knaves", and this age was counted the most deplorable in the history of the world. Their general attitude was one of contempt. "However exalted the satirist's aims, or aimable his temper, a basis of contempt is the ground work of his art". 9 "A man could not write with life unless he were heated by revenge," said Burnett of the Earl of Rochester. ${ }^{10}$

It was not to be expected, therefore, that the new philosophers would receive fair treatment from these wits, or that the new ideas would find appreciation among them. In spite of their protests to the contrary the satirists were looking for someone or something from which to raise a laugh. "To make jests, to live and move in the ludicrous, to find fun in everything under heaven and over hell, or even within these realms themselves, so far as they were voted to exist, was the business of the popular Restoration writers". ${ }^{11}$ They were merciless in their ridicule and undiscriminating in their attacks. Hence, the new science was an easy prey for them, for "of all men the most subject to ridicule are philosophers". ${ }^{12}$

Early in the period rises the sullen and morose figure of Samuel Butler, whose poetic fame rests upon Hudibras. In this poem he ridicules with utter abandon "every theory of the physical order of the universe, whether founded on the deductive or inductive system of philosophy". ${ }^{13}$ His attack was aimed primarily at astrology. Sidrophel and his servant Whachum embody that pseudo-science. But the claims of the master are unbounded,-

8 Stephens, Leslie, History of the Literature and Society in 18th Cent., p. 63.

Ency. Brit., XXI, p. 317, 15th Ed.

${ }^{10}$ Lives, p. 204.

11 Masson, David, Life of Milton, vol. VI, p. 343.

12 Ibid. vol. VI, p. 284.

18 Courthope, J. W., Hist. of Eng. Poetry, vol. III, p. 304. 


\section{" He had been long t'wards Mathematics, Optics, philosophy, and statics, Magic, horoscopy, astrology, And was old dog at physiology." 14}

Here is a quack who has taken over the interests of the true science also. He has made all the new discoveries in the moon, has located the seas, lakes and mountains there $;^{15}$ he "cures warts and corns, with application of medicines to the imagination" $;^{16}$ he has studied maggots in cheese, mites in vinegar and wood; ${ }^{17}$ he is an antiquarian, learned in "hieroglyphics mute of birds" on the oriental obelisk $;^{18}$ he is a star-gazer like Galileo and the other astronomers $;^{19}$ and, in general, he professes a universal knowledge. ${ }^{20}$ And yet he could not tell the "natural cause" why no painter ever draws a full moon on a sign but always the half. ${ }^{21}$ Here is a type characteristic of the writers of comedy; in other words, here is an exploitation of a humor.

This work of exploitation is thoroughly done; almost nothing escapes. The vortex theory of Descartes, ${ }^{22}$ the new atomic theory in physiology, ${ }^{23}$ transfusion of blood, ${ }^{24}$ the stentrophonic tube, ${ }^{25}$ botanical study, ${ }^{26}$ the use of pendulum watches, ${ }^{27}$ "Napier's bones", ${ }^{28}$ mathematical calculations, ${ }^{29}$ sympathetic powder, ${ }^{30}$ the collection of "monstrous births", ${ }^{31}$, chemistry, "bottled

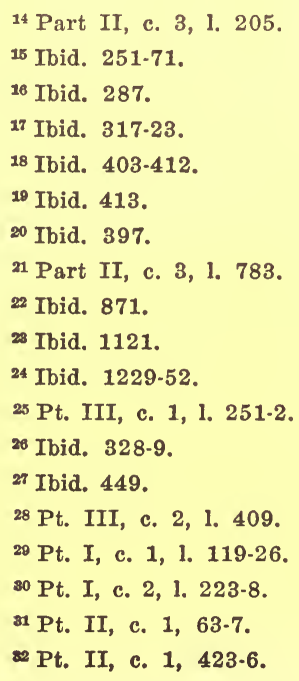


air", ${ }^{33}$-all are here turned to ridicule by this satirist soured by long deferred hope of advancement. There is evidence that he knew what the virtuosi were doing, but there is no reason to believe that he saw any good in their efforts. His real attitude is hard to determine, as is that of every satirist; but, prima facie, he classed Sidrophel, who is probably the famous almanac-maker Lilly, among the new philosophers and on an equality with them. The telescopic investigation of the heavens was to him only a continued study of astrology; physiology was medical quackery; mechanical inventions were mere toys; and geometry was useful for "taking the size of a pot of ale".

Some new light, however, may be thrown on Butler's satiric motive by his later poems, which deal with the same subject. The Elephant in the Moon was inspired by personal animosity towards' Sir Paul Neal, who had persistently declared that Butler was not the author of Hudibras. The inference from his declaration was that Butler could not have written such a poem. This was taken as an affront and was never forgiven. It was well known that the nobleman was a member of the Royal Society; Butler took advantage of this fact in the poem, where he represented Sir Paul Neal and a group of the philosophers as meeting for an observation of the moon through a telescope into which by chance a mouse has crept. Neal sees the mouse in the tube and thinks it an elephant in the moon. The others look and verify his report. Immediately they set to work to write up this sensational discovery for the Transactions, but before they have completed the report some boys look into the telescope and identify the mouse. Great disappointment results among the virtuosi at the loss of this sensational story. Finally, they decide to report it even though false, with the understanding that all will swear to its truth. Their position is thus stated,-

"It is no wonder we're cry'd down, And made the talk of the town That rants and swears, for all our great Attempts, we have done nothing yet, If ev'ry one have leave to doubt, When some great secret's half made out;

$\approx$ Pt. II, c. $2,343-4$. 
And, 'cause perhaps it is not true, Obstruct, and ruin all we do. As no great act was ever done, Nor ever can, with truth alone; If nothing else but Truth w' allow 'Tis no great Matter what we do, For Truth is too reserv'd and nice, T' appear in mix'd societies."

It is, they say, far easier to create a thing like truth than to take the pains to discover truth itself. "But nature would not be thus forsworn, and for their pretended knowledge Butler paid them scorn".

Butler apparently nursed his wrath to keep it warm against Sir Paul Neal. Nor, indeed, did he confine his animosity to this one virtuoso. Other characters can be identified in the poem, as Evelyn, Hooke, Leeuwenhoek, and perhaps Boyle. The whole group were under his ban and were ridiculed without discrimination.

A later fragment, A Satire upon the Royal Society, shows that Butler's mind returned to this theme persistently. It is clear that he contemplated an extensive satire on the new philosophers. These fragmentary lines contain merely an enumeration of the various scientific activities. Comets, meteors, light, magnetism, the course of the sun, the moon, the atmosphere,-these were all their learned speculations,

"And all their constant occupations;

To measure wind, and weigh the air,

And turn the circle to a square;

To make a powder of the sun,

By which all doctors should b' undone;

To find the Northwest passage out,

Although the farthest way about;

If chymists from a rose's ashes

Can raise the rose itself in glasses;

Whether the line of incidents

Rise from the object or the sense;

To stew the Elixir in a bath

of hope, credulity, and faith;

${ }^{34}$ Butler, Samuel, The Elephant in the Moon. 
To explicate, by subtle hints,

The grain of diamonds and flints;

And in the braying of an ass

Find out the treble and the bass;

If mares neigh alto, and a cow

A double diapason low"'.35

In general, Butler's attitude is severely satirical. He finds nothing to praise in the new interest. To him all scientific learning is "but a corn or wart in the skin of Judgment, Sense, and Art";38 scientific apparatus consists of "Gimcracks, Whims, Jiggumbobs" ;7 and the whole result of scientific study is "to crack a man's brain in plodding on to know that which is never to be known". ${ }^{38}$ Whether his judgment admitted the truth of any of the new discoveries cannot be determined. He seems in real doubt about the motion of the earth, -

"The motions of the earth or sun

(The Lord knows which) that turn or run"'.39

But this is as near a serious position as he ever attained. The rest is mockery.

Hudibras, as is well known, was immensely popular. Even the king read it, laughed over it and quoted it. The author was praised; preferment seemed at hand; and then he was neglected. Such, it would appear, was the general effect of this satire. "What effect," wrote Dr. Johnson, "this poem had upon the publick, whether it showed imposture or reclaimed credulity, is not easily determined. Cheats can seldom stand long against laughter. It is certain that the credit of planetary intelligence wore fast away." But it has already been shown that another force was at work destroying the pseudo-science of astrology, i. e. the search for natural causes. Butler was keenly aware of the hypocrisy in this business and was justified in his presentation of Sidrophel and Whachum. His mistake, however, was to let his personal feeling

${ }^{35}$ A Satire Upon the Royal Society, 85-104.

se Hudibras, Pt. III, c. 1, 108-9.

37 Upon Human Learning.

${ }^{38}$ A Fragment.

30 Sat. upon Weaknesses and Misery of Man.

40a Johnson, Samuel, Lives of the Poets, I, p. 216. 
blunt his power of discrimination, so that he was led to scoff at the whole new movement. "There is a great difference", said Shaftesbury wisely, "between seeking how to raise a laugh from everything, and seeking in everything what justly may be laughed at. For nothing is ridiculous except what is deformed; nor is anything proof against raillery except what is handsome and just"..40 Here was Butler's defect and this greatly nullified the influence of his satire. The new science was destined to increase; Butler's power was sure to decrease.

In other satiric verse of this early period the new science finds only incidental expression. In Charles II's Court was a group of scoffers who sharpened their wits against men and manners, but they were almost wholly engrossed with polities and society. The leader of this "mob of gentlemen who wrote with ease" was John Wilmot, Earl of Rochester. His attitude is typical. To him it is folly to leave the pleasures of society for useless, or at most altruistic, studies.

"Nature's as lame in making a true fop,

As a philosopher; the very top,

And dignity of folly we attain

By studious search and labor of the brain,

By observation, counsel, and deep thought'". ${ }^{41}$

This flippant treatment is found generally. The Earl of Dorset ridicules Boyle's study of light in this fashion, -

"So have I seen in larder dark

Of Veal a lucid loin;

Replete with many a brilliant spark,

As wise philosophers remark,

At once both stink and shine",.42

Lord Buckhurst, in his burlesque on Sir Robert Howard's Duel of the Stags, describes in mock heroic style a fight between two crabs. But whether they fought with proboscis, or horns, or tusks,--

"Some Greshamite perhaps, with help of glass, And poring long upon't, may chance to guess." 43

40 Characteristics, vol. 1, p. 85.

41 Artimisia in Town to Cloe in the Country.

22 On the Countess of Dorchester, 1680.

4 The Duel of the Crabs. 
It was at this time that Andrew Marvell's pen flowed with vitriolic wit. He sought chiefly to correct political abuses, but touched again and again upon the new science, and always to ridicule it. The atomic theory is derided in The Clarendon HouseWarming; ${ }^{44}$ the telescopic observations of the sun in To the King; transfusion of the blood in Britannia and Raleigh. A selection from his Instructions to a Painter about the Dutch Wars, 1667, will illustrate his attitude.

"With Hooke then through your microscope take aim,

To see a louse brandish a white staff,

Paint then again her Highness to the life

Philosopher beyond Newcastle's wife". ${ }^{45}$

There follow some absurd experiments by which to restore virginity after childbirth and to mature royal heirs quickly.

"Hence Crowder made the rare inventress free

Of 's Highness's Royal Society."

Many miscellaneous satirical references occur. John Oldham satirized the art of flying in his Satire on Jesuits. ${ }^{46}$ The Duke of Buckingham poked fun at the new inventions in The Rump-Parliament. Physiological studies were ridiculed in An Occasional Reflection on Dr. Charleton's "Feeling a Dog's Pulse at Gresham College". ${ }^{47}$ The investigation of mineral springs found satiric treatment in Tunbridgia; or, The Pleasures of Tunbridge. ${ }^{48}$ Sir Samuel Morland's inventions were ridiculed in Cullen with his Flock of Misses (1679). ${ }^{49}$ New projects, in the virtuoso's manner are discovered in the poem On the Late Inventions of the New Light, ${ }^{50}$ and on The Late Invention of the Penny Post, ${ }^{51}$ In 1691 Alicia D'Anvers sent a Country bumpkin to Oxford, where he beheld with wonder and amazement the scientific apparatus and the rarities of the virtuosi. ${ }^{52}$

${ }^{44}$ St. XV.

${ }^{45}$ Sat. III.

48 11. 141-7.

${ }^{47}$ Attributed to Butler.

48 Poems on State Affairs, vol. II, p. 205.

${ }^{49}$ Ibid. I, p. 133.

${ }^{50}$ Ibid. II, p. 244.

${ }^{61}$ Ibid. II, p. 246.

${ }^{52}$ Academia; or, The Humours of Oxford in Burlesque Verse. 
Throughout all of this verse the attitude is the same. The satirists came to this new interest to scoff. They were never serious, never sincere, never fair, never candid. New science was to them another folly, another evidence of England's decadence, and those who followed it were fools and knaves, as much to be scorned as the veriest fop, as much to be ridiculed as the worst quack, as much to be despised as the religious hypocrite, and as much to be lashed with satiric whips as the most dishonest political intriguer. There is here no appreciation of unselfish devotion to truth, no respect for men of high and noble character, no belief in the possibilities of the new philosophy.

William King stands between the wits of the Restoration and those of Queen Anne's reign. Besides, for his own sake he deserves individual treatment. He was a writer of charming cleverness and of brilliant wit. His satire was keen yet full of fun. $\mathrm{He}$ wrote apparently with ease and facility. Politics, society, and religion occupied his pen for the most part, but he glances again and again at the new science. In Just as you Please; or, The Incurious, there is an experiment made by a virtuoso who had a mind to see a man that would never disagree with any expressed opinion; in The Stumbling Block, there is a good-natured satire on the old atomic theory and on the new atmospheric studies, -

"A Vacuum's another maxim;

Where, he brags, experience backs him;

Denying that all space is full, From inside of a Tory's skull". ${ }^{53}$

But it was in the Transactioneer (1700) that he struck out most boldly against the Royal Society and its work. This was intended to be a burlesque on the Philosophical Transactions. ${ }^{54}$ These headings, "taken at random", will illustrate the nature of the subjects treated; "Eggs in the Cauda of a barnacle. Four sorts of Lady's Bugs. A Buck in a snake's belly. A Shower of Whitings. A Shower of Butter to dress them with." "55 The sole purpose, it may be seen, was to raise a laugh. The same is true of King's satiric verse. Here is a specimen of some crude lines in ironic vein,-

53 The Stumbling Block, 1. 308-11.

54 The Transactioneer, with some of his philosophical fancies, in two dialogues.

${ }^{5}$ Quoted in Weld's History of the Royal Society, p. 352. 
"The Merchants on the Exchange doe plott

To increase the Kingdom's worthy trade;

At Gresham College a learned Knott,

Unparalleled designs have laid,

To make themselves a Corporation,

And know all things by demonstration.

This noble Corporation

Not for themselves are thus combin'd,

But for the public good o' th' nation,

And general benefit of Mankind.

These are not men of common mould

They covet fame, but condemn gold.

The College will the whole world measure,

Which most impossible conclude,

And navigation make a pleasure,

By finding out the longitude;

Every Tarpaulian shall then with ease

Saile any ship to the Antipodies.

The College Gresham shall hereafter

Be the whole world's university;

Oxford and Cambridge are our laughter;

Their learning is but pedantry;

These new collegiates do assure us

Aristotle's an ass to Epicurus". ${ }^{58}$

The awkwardness of these lines do King an injustice, but they show the spirit of his raillery. Again there is a desire to raise a laugh at whatever expense. There is no calling of knaves and fools, but he usually accomplishes that most difficult feat of making "a man appear a fool, a block-head, or a knave, without using any of those opproprious terms". ${ }^{57} \mathrm{He}$ was a master of "the nicest and most delicate touches in fine railery of which satire consists". ${ }^{58}$

At the turn of the century there are found a number of satiric thrusts at the new science. Samuel Garth, angered at the quarrel between the physicians and apothecaries over dispensing drugs

${ }^{8}$ See Weld, History of Royal Society, vol. II, p. 323.

${ }^{87}$ Dryden, Discourse concerning the original and progress of satire.

${ }^{6}$ Ibid. 
free of charge to the poor, wrote The Dispensary (1699) "to purge his mind". The satire is on astrologers and physicians, and generally confines itself to the abuse among the men of these two fraternities. Like other satirists, however, he does not always discriminate; Sloane and Bentley are no better than Lilly and Charles Boyle. ${ }^{59}$ The author was much praised on account of this poem because the general reader felt he was a true champion of the opressed. John Pomfret repeats this satire in Reason (1700). "More than once", he says, "we have seen that blundering Sloane, missing the gout, by chance has hit the stone. Among the 'impious race' of physicians there is a continued war between alkalis and acids". The sting of his satire is found in these two lines,-

"What's all the noisy jargon of the schools,

But idle nonsense of laborious fools?"

Blackmore, in his eagerness to establish orthodox belief, found himself denouncing all forms of human philosophy, in the first two books of The Creation. "There is no philosophy", he cries, "without a God". ${ }^{60}$ Descartes, Gassendus, Copernicus, Ptolemy, Kepler, Newton pursued their studies in vain. "Move, which will please you, earth or sun", ${ }^{61}$ account for the mountains by myth or for the tides by the motion of the earth or the influence of the moon, ${ }^{62}$ turn the world as you will and by what force you will, magnetism or gravitation, ${ }^{63}$ in the final analysis the true solution to every question is,- "This is done by the power of God". It was poetic enthusiasm that carried Blackmore to this point of utter repudiation. As will be shown later, he was really in accord with the new ideas, at least in physiology. And even here in spite of his opposition he has caught a new glimpse of the immensity of space.

"Regard the orb sublime, in ether borne,

Which the blue regions of the skies adorn;

Compar'd with whose extent this low hung ball,

Shrunk to a point, is despicably small." ${ }_{64}$

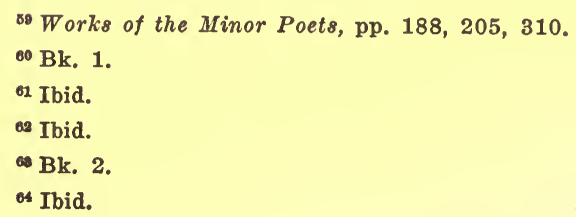


$\mathrm{He}$, too, must take a thrust at Sloane, as seen in his satiric poem the Kit-Cats (1709). Blackmore, himself, became the target for many a witty line on account of his heavy, monotonous verse, which few ever read. His attitude, therefore, is not of much importance.

The group of brilliant Queen Anne wits found much satiric material in the new science. Prior, the eldest of them, got much fun out of ridiculing the different philosophic theories in Alma; or, The Progress of the Mind. Fame, he says, awaits the men who will reconcile Aristotle and Gassendus.65 All systems have unsound foundations. If one questions the premises of any philosopher's theory, then he is rendered helpless. Deny to Descartes his "subtil matter" and he has nothing left; refuse to accept the elastic force of matter and "Sir Isaac would look odd"; disprove the existence of the philosopher's stone, and "how could our chemic friends go on?" Not only so, but the whole activity is misapplied,

"Circles to square and cubes to double, Would give a man excessive trouble;

The Longitude uncertain roams,

In spite of Whiston and his bombs" ${ }^{66}$

The search after rarities has no attraction for him and men are fools to yield to such a curiosity. ${ }^{67}$ The physiologists, too, have gone to a foolish excess in their search for likenesses in bodily structure between brutes and men. ${ }^{68}$

Prior's is a contemptuous attitude. Like Blackmore, he claims that nature is too subtle for man to understand; the wisest answer to all questions is to say, "Thus the Creator has done". There is no reason for confidence in any man-made theory; for,-

"Forc'd by reflective reason, I confess,

That human science is but guess." 69

Swift devotes little attention in verse to the new science. In his burlesque Ode to the Athenian Society occur such lines as these,-

65 Lines 244-6.

66 Alma, Canto III, 366-9.

6 Ibid. 448-83.

6 An Ode, 1689.

eo Alma, 739-40. 
"And hopes to lengthen life by a transfusion of breath, Which yet who e'er examines right will find

To be an Art as vain as bottling up of wind". ${ }^{70}$

If such scientific information was really dispensed through the medium of The Athenian Mercury, its original source was certainly the Royal Society. The same is true of the references in these lines from an Ode to Music,-

"The longitude miss'd on

By wicked Will Whiston;

And not better hit on

By good Master Ditton." ${ }^{1}$

The Broken Mug contains a scene on Mt. Parnassus where a discussion has been carried on among a group of friends as to whether "The earth mov'd, or the sun",-

"Who writ the best Philosophy

Copernicus or Ptolomy.

Whether they were not both outdone,

By Newton's Principles alone."

Swift's satire on the new science, in verse, is good-natured. He never seemed to have endeavored seriously to exploit that humor, doubtless because he dealt with it so fully in prose. The new philosophy has entered to such a small extent into his poetry as to become almost negligible, and no definite attitude can be determined.

Other poets took their fling at the new philosophy. John Byrom has some derisive verses in A Full and True Account, The Disection of a Beau's Head, ${ }^{72}$ and.The Astrologer. The first poem, written in his youth, ridicules "The Goddess Shorthand, bright celestial maid", a system recently proposed before the Royal Society; the second is, as the name suggests, a burlesque on dissection; the third is an invocation to astrology, "Goddess divine, Celestial Decypheress". All these show the crudities of youth, the affectation of a sophomore. They are of no value either as verse or as satire.

In Fenton there is found once more that form of piety which

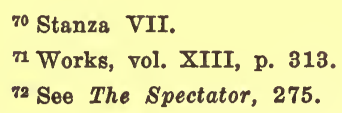


considers man vain and presumptuous who tries "with random guesses",-

\section{"To sound Thy searchless providence,}

From which he sprang." "73

The best answer to all scientific inquiries, he repeats, is that God so ordained. Otherwise men will reach such absurd conclusions as the "sage Cartesians" hold, who declare that souls stand tiptoe on the pineal gland. ${ }^{74}$ Here is his attitude summed up in four lines,-

"That knowledge, which from reason flows,

Unless Religion guide its course,

And Faith her steady mounds oppose,

Is ignorance at best, and often worse". ${ }^{75}$

The same kind of piety inspired Isaac Watts and determined his attitude toward the new ideas. Man has a "silly wandering mind" that resents the close confinement of the flesh, and unless curbed will "coast round the narrow shores of flesh and sense","Picking shells and pebbles thence." '76 Watts' contempt for human learning finds expression in these rather vigorous lines,--

"Touch, heavenly Word, O touch these curious souls;

Since I have heard but one soft hint from thee

From all the vain opinions of the schools

(That pageantry of knowing fools)

I feel my powers releas'd, and stand divinely free". ${ }^{77}$

Such casual thrusts may be passed by with bare mention, as Gilbert West's "supercilious pedant train",78 Somerville's "precarious science vain", in which all creation is "nature's puppetshow", 79 and his declaration that "the best elixir is a friend", 80 Richard Duke's classification, "Mountebanks, Quakers, Chemists, Trading varlets", 81 and Parnell's "grave frenzy of the chymic

${ }^{73}$ An Ode.

${ }^{74}$ The Fair Nun.

${ }^{70}$ An Ode.

${ }^{70}$ True Riches.

${ }^{77}$ True Learning.

${ }^{78}$ Education.

"The Officious Messenger.

${ }^{8}$ To William Colmore.

st The Review. 
fool".82 The same attitude, merely hinted at, is common to all. These men are scoffers, without faith in the new science and without any appreciation of the men and achievements. These lines present the very essence of their opinions,-

"What can these idle Gimcracks mean;

Ye World-Makers of Gresham-Hall,

Dog Rover shall confute you all". ${ }^{83}$

William Shenstone addressed a poem of considerable length To the Virtuosi. There is in it a vein of contemptuous, satiric raillery, but it seems to have been intended for good-natured burlesque. The important thing in it is the characterization of the scientist at this late period in the eighteenth century,- - "those curious Wights! to whom so fair the form of mortal flies is!" Men of science "sigh for nature's vermin", "and deem those grubs beyond compare which common sense despises". The same contempt appears in The Progress of Taste, where Damon has fallen into the grasp of this scientific humor,-

"Till passion, misdirected, sighs

For weeds, or shells, or grubs, or flies!"

Such an interest, says Shenstone, might be admired in boys and girls "of fifteen years and more", but in adults it becomes a folly. A far "nobler passion is to love",-

"Tis time more social joys to prove;

'Twere your nobler tasks to love". ${ }^{84}$

Shenstone's contempt for physicians and apothecaries is given in The Charms of Precedence.

This poet failed to understand the scientific passion. It was much better in his judgment to spend one's time in social pleasure than in prying into the secrets of nature, i. e., in studying the forms and habits of insects. For insects to him were only "nature's vermin", and the man who wasted his life in a contemplation of them was as much to be despised as they.

Edward Young wrote some cutting satire on the new science in The Universal Passion. He decried that passion in men for antiques which leads them to spend all their money for these use-

82 To Mr. Pope.

Somerville, The Officious Messenger.

s4 The Progress of Taste. 
less things while their families come to want. ${ }^{85}$ The following lines show his attitude:

"Nothing exceeds in ridicule, no doubt,

A fool in fashion, but a fool that 's out.

But what in oddness can be more sublime

Than Sloane, the foremost toyman of his time?

His nice ambition lies in curious fancies,

His daughter's portion a rich shell inhances,

And Ashmole's baby-house is in his view,

Britannia's golden mine, a rich Peru!

How his eyes languish! How his thoughts adore

That painted coat, which Joseph never wore!

He shows on holidays, a sacred pin

That touch'd the ruff, that touch'd Queen Bess's chin".86

"Some nymphs", he laments, "prefer astronomy to love", 87 and make appointments with Desagulier and Whiston instead of with a beau. But Young has only scorn for female philosophy. "Sophronia" may try numberless vain experiments with air-pumps, may gaze to-night with rapture on the starry sky through the telescope, but to-morrow,-

\section{"( 0 , fickle sex!).}

Lo! Pug from Jupiter her heart has got,

Turns out the stars, and Newton is a sot." "88

Here again is the attitude of comedy. The followers of science are fools and knaves, all the worse, because this philosophy, which was new in the seventeenth century, is now "gone out of date". Antiquarianism, astronomy, and physics are follies or worse, and need the lashing of satiric verse.

"Satire! had I thy Dorset's force devine,

A knave or fool should perish in each line;

Tho' for the first all Westminster should plead,

And for the last, all Gresham intercede." ${ }^{89}$

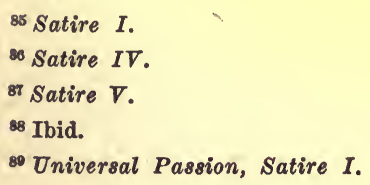


How the poet's attitude was changed in later years will be shown hereafter, but as revealed at this early period it is cruelly severe.

Mark Akenside wrote a poem in Spencerian stanzas on the character of the scientist in The Virtuoso. It is satiric in tone, but good-naturedly so. He regards the scientific interest as a "phantasy" whose power fills the mind to the exclusion of judgment. A man so possessed looks at the world "with vitiated sight", so that he neglects his family and forgets his friends in the mad pursuit of "painted trifles and fantastic toys." Here the virtuoso stands in clear outline,-

“'Book-learn'd and quaint: a virtuoso hight.

He many a creature did anatomize,

Almost unpeopling water, air, and land;

Beasts, fishes, birds, snails, caterpillars, flies,

Were laid full low by his relentless hand,

That oft with gory crimson was distained;

He many a dog destroyed, and many a cat;

Of fleas his bed, of frogs the marshes drained,

Could tellen if a mite were lean or fat,

And read a lecture o'er the entrails of a gnat.' ${ }_{90}$

The knowledge to which this virtuoso lays claim is practically unbounded-except by usefulness. That realm he never entered. $\mathrm{He}$ is learned in the various manners of ancient times, and in rarities,- "How the Greek tunic differs from the Roman gown"; he is a curious medallist; he has a rich museum, containing airpumps, prisms, a Memphian mummy-king, phials of live insects, a tripod of the Pythian Maid, a crocodile, and a table full of rarities such as a Bahaman spider's carcass, "a dire serpent's golden skin", and some Indian feathers.

There is here no seriousness, no bitterness; the poet declares, simply, that the man is foolish who will devote himself to a pursuit of such knowledge, and yet he may be happy in his folly. As for the poet, he looks on with good-natured ridicule, exploits the absurdity of the "odd humor", and turns away to write a love lyric to Chloe.

In the poetry of Pope, that satiric epitome of the age, is found an extended treatment of the new science. It is so closely inter90 Ibid. Stanza II. 
woven, however, with other matter that it is a difficult task to extract it. The poet's position may be made clear by a general exposition with references interspersed and with occasional quotations where the passages are illuminating. His mockery of astrology is found in the last eanto of the Rape of the Lock; ${ }^{91}$ his scorn of the antiquarian humor is disclosed in the opening lines of Epistle IV of the Moral Essays. His own claim upon "Reason free and unposs ' $t$ "' he states thus boldly in the Imitations of Horace, Bk. I, Ep. I,-

"But ask not, to what Doctors I apply?

Sworn to no master, of no sect am I;

As drives the Storm, at any door I knock;

And house with Montague now, or now with Locke." ${ }_{92}$

But for a fuller expression of his attitude one must turn to the Essay on Man and the Dunciad. In the former, however much Pope may have borrowed from Bolingbroke in philosophic ideas, the manner of treatment and the bias of mind are the poet's own. These may be examined with no cencern for influences. His attitude is found to be largely the ultra-pious position taken by Prior and Watts; namely, that man is presumptuous to try to understand the laws of nature, his proper attitude is rather one of acceptance and reverence.

"Go!!" cries Pope scornfully,

....."Wonderous ereature! mount where science guides,

Go, measure earth, weigh air and state the tides,

Instruct the planets in what orbs to run,

Correct old Time, and regulate the sun". ${ }^{93}$

Let those proud men teach eternal wisdom, and when that is done, "drop into themselves, and be a fool". ${ }^{94}$ Bacon, the archscientist, is to him "the wisest, brightest, meanest of men;" 95 and here for the first and last time Newton is attacked,-_"a mortal man who dared unfold all nature's law". So high has he risen in the admiration of his disciples that they show "a Newton as we show an

11 Canto V, 11. 127+.

$9211.23-6$.

Ep. II, 19-22.

Ibid. 29-30.

95 Ibid. IV, 282. 
Ape". But if one will really know the truth, ${ }^{98}$ he must first take modesty as his guide, must strip off the "equipage of Pride", "Learning's Luxury", and "Idleness", "tricks to show the stretch of human brain", then will he see revealed how little is the sum of actual knowledge possessed by man. ${ }^{97}$ Behind and beyond every human theory lies an unanswerable question; that is God. Man's duty, therefore, is to trace the beneficent design of his creator in the world about him and cease to crack his brain over natural causes. The attraction of atoms, the movement of the spheres, the orders of living creatures, the harmony in the universe are matters for praise, not investigation. Therefore, the Indian is a happier man than the scientist, for

"His soul, proud Science never taught to stray

Far as the solar walk, or milky way". 98

More pointed satire is found in the Dunciad, especially in Bk. IV, the diatribe on education. Here "Science groans in chains", but mad Mathesis (mathematics) runs free and lifts her ecstatic stare to pure space, and

"Now running round the circle, finds its square"."99 The Cartesians with their "Mechanic Cause" nobly take a "Priori Road", and build up nature as they will.100 Antiquarians, botanists, zoologists come bearing as their tributes, "a nest, a Toad, a Fungus, or a Flower". ${ }^{101}$ One virtuoso seeks preferment from the queen of Dullness because he has madly pursued and ruthlessly slain a lovely butterfly,-

"Whose spoil this paper offers to your eye,

Fair ev'n in death! this peerless Butterfly." ${ }_{102}$

So, Pope declares, there is a bias to every mind; some dullards are aroused by a humming-bird, some find pleasure in dissecting "a member of the cockle-kind", some "may wander in a wilderness of moss", some run mad after comets, some

จ6 1. 34.

on 11. 43-52.

${ }^{98}$ Epistle I, 101-2.

901.21.

1001.31.

101 11. 465-71.

1021.380. 
"Impale a glow-worm, or Vertú profess, Shine in dignity of F. R. S." "103

All unite in obeying their Queen's last command,-_"be proud, be selfish, and be dull"'.105

In his attack there is no mercy in Pope's heart. Pseudo-science and true science fall alike to the part of fools. The antagonism he feels is really innate; it is the artist's nature meeting with the cold intellectualism of science; it is a poet finding facts unwarmed by imaginative fervor. Hence, there is neither sympathy for nor appreciation of ${ }^{106}$ the new ideas; hence, is the bitter irony of these lines that are the acme of Pope's satire against the whole scientific attitude,-

"O, would the Sons of Men once think their eyes

And reason giv'n them but to study Flies!

See nature in some partial narrow shape

And let the author of the whole escape;

Learn but to trifle; or, who most observe,

To wonder at their Maker, not to serve"'.107

It was thus that the new science was represented in the satire of the period. In a large measure there was an exploitation of the new interest as a humor, just as the comedies of the times treated it. In such a process no discrimination between pretense and true worth can be found, or is to be expected. As a matter of fact, writing satire became for these poets as great a humor as they were ever able to find in the "follies and foibles" of other men. This peculiar quality or bias of mind so possessed them that it drew their affects, spirits and powers "in their confluction, all to run one way". By Ben Jonson's own definition, therefore, these writers were dominated by a satiric humor, which sought to render absurd the interests of all men, which lived and moved and had its being in laughter not always pleasant. It was born in Butler and perished with Pope.

A peculiar phase of this satiric attitude appeared in those rather

109 11. 435-6.

3051.584.

106 See infra. for Pope's use of facts.

107 The Dunciad, IV, 1. 454-9. 
extreme pietists, such as Prior, Blackmore, and Watts, who professed to feel that it was an act of sacrilege to investigate the laws of nature, because this was aspiring to divine wisdom. To seek for natural causes of natural phenomena, said they, is to displace God by a mechanical contrivance. A far simpler and more dogmatic way to solve the vexing questions respecting the world of nature is to answer briefly and emphatically, as Blackmore did,"this is done by the power of God".

There was a widespread feeling of contempt among the satirists for those virtuosi who had a passion for studying "natures vermin" and for collecting rarities. Thus, Hans Sloane, Secretary of the Royal Society and Keeper of the Ashmolean "baby-house", became "the great toyman of his time". A delight in "glittering trifles" was fit for children, as Shenstone expressed it, but a more worthy occupation for men was social intercourse.

Sometimes, though not frequently, the scientists themselves were satirized. Sir Paul Neal, Hooke, Leeuwenhoek, Evelyn, Sloane, and even the great Newton himself received satiric thrusts. There was in the case of Butler's attack on Sir Paul Neal, and in Garth's satiric criticism of Sloane, a motive of personal feeling. In general, however, the characters of the scientists were respected.

After a study of the unfair, unjustified, and indiscriminate attacks upon the new philosophy, one reads with a feeling of considerable irritation the words of Shaftesbury;- "The satirists seldom fail in doing justice to virtue". ${ }^{108}$ Even granting sincerity of purpose to the writers-a virtue which must be denied themthe best word for them is that they did not yet understand the new movement. Nor can one accept without reluctance Shaftesbury's fundamental maxim in defense of satire,-that "ridicule is a test of truth". But, if it be so, then was the new science solidly based upon a true foundation, for through all the assaults of satire and abuse the men of science went patiently forward conquering and to conquer.

It is a relief to quit the brilliance of satire for a homelier and kindlier verse. "If inexhaustible wit could give perpetual pleasure", wrote Dr. Johnson, "no eye would ever leave half-read the work of Butler. But astonishment is a toilsome pleasure; he

108 Characteristics, vol. I, p. 93. 
(the reader) is soon weary of wondering, and longs to be diverted". ${ }^{109}$ This is precisely the feeling with which one turns to trace the growth of appreciation which the new science found among the poets. It will here be shown that concomitant with satire there developed another attitude towards the new philosophers and their work. The newly discovered ideas gradually found literary expression. First came the sublime scenes revealed by the telescope, then the curious mechanism of the human body, then a new insight into external nature through the scientist's interest and power to observe.

Astronomy soon joined itself to a religious contemplation. In a new way the heavens began to declare the glory of God and the firmament to show his handiwork. Prior, for all his strictures on scientific presumption, found himself inspired by a study of the sky. The sun still ran round the earth for him ${ }^{110}$ and the power of astrology was still strong, ${ }^{111}$ but the course of the stars, "the myriads of moons and earths sown through that space, which we call air and sky", revealed by the telescope and calculated by mathematics, demanded his utmost admiration. He could not, indeed,

"Make arithmetic and epic meet

And Newton's thoughts in Dryden's style repeat,"112

nor could he forget that the human mind has its limits, that every man must reach the point where "Faith, for Reasons glimmering, shall give her immortal perspective." "113 But Prior illustrates the first step toward real poetic appreciation. Astronomy thus led the way through piety; the other sciences followed slowly.

Blackmore, after denouncing all physical systems of the universe for the single assertion, "This is done by the power of God", turned to the new physiology with the enthusiasm of a discoverer. Book VI of The Creation traces with minuteness the course of the blood as shown by the microseope, ${ }^{114}$ and praises Harvey highly. for his.scientific work. ${ }^{115}$ The physician in Blackmore grows more

109 Johnson's Lives, vol. I, p. 212, Butler.

${ }^{210} I$ am that $I$ am, 38-41.

111 Presented to the King, 1-3.

112 A Letter, 1704, 1. 77.

${ }^{113} I$ Am that I Am, 11. 100-1.

${ }^{114}$ p. 372 .

115 p. 373. 
and more as the poem progresses and the poet less and less. When the eirculation of the blood is completed, he takes up the process of digestion and proposes to "pursue this theme as far as the learned observers know". 116 What Blackmore understood of the new science he appreciated. To this he gave such poetic expression as he could. The spirit of the man was appreciatively willing, but he was poetically weak.

Pomfret, in Reason and The Divine Attributes, grows enthusiastic over the extended bounds of the sky. In the former poem there is a vigorous expression of an idea fundamental to the new scientific attitude:

"Does not that foolish deference we pay

To men that liv'd long since, our passage stay,

What odd, preposterous paths at first we tread,

And learn to walk by stumbling on the dead!"117

In the religious lyrics of Isaac Watts there is generally the astronomy of the Old Testament scriptures. The Creator is represented as sitting on "an awful throne", "whirling the planets round the poles". ${ }^{118}$ "The "tuneful spheres roll through the heavens"; the sun moves round the earth. And yet, even here, there is the new spirit, the new conception of space:- "earth's but an atom". In Free Philosophy, especially, there is the new spirit of inquiry. "I hate these shackles of the mind", he declares, "Thoughts should be as free as fire and wind". Clearly, then, not even this pious man could escape some tincture of the new philosophy.

The Ecstasy, by John Hughes, is after the same manner. It is a poem filled with unbounded enthusiasm for the Newtonian discoveries. The poet sends his spirit through vast space, beholds the system of the world as Newton described it, draws near enough to the moon to identify her lakes, mountains, and groves, looks back to discover the earth itself turned to a moon, "her seas shadowy spots, her land a milky white". He inspects Jove's four moons, Saturn's rings, -

"And other suns, that rule by other laws,

Hither their bordering realms extend".

118 p. 373.

117 Reason.

${ }_{118}$ To Mr. C. and S. Fleetwood. 
He sees unafraid a meteor, the "great Columbus of the skies",-

"'Tis Newton's soul that daily travels here

In search of knowledge for Mankind below." "119

The spirit of Newton is invoked to teach the poet the way of each wandering comet, and to explain scientifically the rainbow. Hughes, as far as he was able, transformed into poetry the new knowledge of astronomy. In his mind there was no fear of impiety; all was admiration and wonder and delight. He could not know too much.

A topical poem of very little value, by Thomas Yalden, addressed to a Mr. Watson, "on his Ephemeris of Celestial Motions, presented to her Majesty", shows how fully the gravitation theory was accepted. This mechanical device was used to illustrate the position and motion of the planets. From Yalden's description it can be seen to follow Newton's new system of the universe. But of more importance is a poem by him, entitled The Insect. This is one of the very earliest attempts to use for poetic material the world of minutiae. "Tis nature's smallest products please the eye", wrote the poet. Monsters are formed to cause terror, but insects to delight. In these latter nature works with exquisite fineness and perfects every part no matter how small. ${ }^{120}$. There is a touch of originality in the poem that startles the reader to attention.

As a mark of precocity stands the poem of Richard Glover, prefixed to Pemberton's edition of Newton's works. The youthful poet discourses at weary length on the discoveries of the great scientist. Gravitation, the analysis of colors, and the theory of sound transmission are treated with fulsome praise. Only one thing that piques the poet's curiosity has Newton left unsolved;"What", he asks, "is that subtle spirit which causes a deflection of the rays of light from their straight course to give color to the rainbow in the sky, the grass in the meadow, the flowers of the fields?"

The remaining poets fall logically into two general groups; (1) those who found fresh material in the open fields, as John Philips, Thomson, Dyer, and Somerville, and (2) those who found a new,

110 The Ecstasy.

${ }^{120}$ Poem on Sir Isaac Newton. 
half-mystical inspiration in the heavens above, as Savage, Brooke, Young, and Akenside. The poems from the first group are filled with the hitherto unappreciated commonplace things of country life; the poems from the second group are more formal and more religious. The purpose here is to show that scientific curiosity permeates the work of both groups, that both employ the material out of which was to be contructed the new natural history of the world.

John Philips, in Cider, wrote out of an interested and longcontinued observation. The orchard was to him a laboratory wherein he made experiments in grafting, pruning, fertilizing. He had examined with curiosity through the microscope the embryonic tree in the kernel $;^{121}$ he had seen the mites that prey on trees and fruit; he had noted the times and seasons with an inductive, commonsense judgment. ${ }^{122}$ In spirit and method he was in accord with the new philosophers.

Thomson, likewise, was possessed of the new spirit. He roamed the fields "with philosophic eye and inspect sage". The meteor that sped across the sky did not frighten him as it did the "superstitious multitude". He surveyed it curiously, "inquisitive to know the causes". ${ }^{123}$ The changes of the seasons he endeavored to interpret in terms of chemistry. ${ }^{124} \mathrm{He}$ was familiar with the recent scientific activities. ${ }^{125}$ Boyle and Newton were mentioned by him with special praise. ${ }^{126}$ He felt himself, in general, to be in perfect sympathy with the new science.

"Fair thy renown

In awful sages and in noble bards;

Soon as the light of dawning science spread

Her orient ray, and waked the Muse's song".

Thomson, more nearly than any other of these poets, has followed the exhortation of Thomas Sprat, "to read in the great Book of Nature, to walk in its Garden and taste its plenty". If the new

$121 \mathrm{Bk}$. I.

122 Bk. II. Autumn, p. 141, Crowell.

${ }^{122}$ Autumn, p. 105, Crowell, "Whate'er the wintry frost nitrous prepared and summer suns concocted strong".

${ }^{124}$ Summer, p. 97, To memory of Sir Isaac Newton, also p. 406.

120 Autumn, p. 146.

128 Spring, p. 15. 
science did not furnish him fully the promised reward of fresh imagery, it did aid him with a new interest. The facts of nature were not to him cold and lifeless, but warm and living. In the Seasons imagination and reason meet on terms of amity, and merely await the greater genius of Wordsworth to wed them.

In John Dyer's The Fleece there is the same spirit of interested observation. The subject-matter is humble and homely but the enthusiasm of the poet is ever present. He wrote like an expert shepherd. He seemed to know the causes of disease and their cures $;^{127}$ he had patiently observed the habits of the flock; $;^{128}$ he knew the shearing time, the lambing time, the care of the fleece, and its later process of manufacture. With all of his discursiveness and preaching, like Thomson, his method of gathering information// was that of the new science,- - observation and experiment.

One would not expect to find any new science or old science in Somerville's The Chase, and yet the scientific attitude is there. This lover of dogs has made a careful study of them, so that he too can speak as an expert in his field. He has given an explanation of how a hound follows the scent of a deer, which might in substance have appeared in the Philosophical Transactions,-

"The blood from the heart incessant rolls

In many a crimson tide, then here and there

In smaller rills disparted, as its flow

Propelled, the serous particles wade

Through th' open pores, and with the ambient air Entangling mix." "129

This effluvium, escaping through the pores of the skin, clings to the grass, shrubs, and bushes, unless destroyed by rain or heat. The nostrils of the hound in pursuit sucks in this effluvium and discovers the scent.

The poet had seen the weather signs, he knew the care of the horse, the symptoms and the treatment of hydrophobia. The habits of the deer, the hound, the hare, and the wily fox, this poet of the open fields also knew. His lines are filled with the freshness and vigor of the outdoor life; he wrote out of the enthusiasm

$127 \mathrm{Bk}$. I.

$128 \mathrm{Bk}$. II.

${ }^{129}$ Canto I. 
of a first-hand, intimate knowledge. Through all of his verse there is evidence of careful, interested observation and of varied experience. Somerville had the intellectual attitude of the scientist combined with the feeling of a poet.

Into this school of Thomsonian poetry has entered the new scientific spirit. It is not claimed that these poets were primarily inspired by the new science, but clearly enough their habits of mind were in accord with it. Their eyes were opened to see the wondrous things in commonplace life. Interest in bugs and mites was not to be despised by them; in the sheep-fold, in the kennel, in the orchard, there was the subject-matter of philosophy and poetry. In them was science becoming the handmaiden of literature.

With Richard Savage's The Wanderer (1729) began that strain of oriental mysticism inspired by the night and the stars. The rapt poet wanders alone in the dark and with feelings of ecstasy,

"Sees, round new countless suns, new systems roll;

Sees God in all! and magnifies the whole!"'130

$\mathrm{He}$ is enraptured by the wonderful northern lights, the fleeting comets where "half-circling glories shoot in rays of gold". To "Fancy's eye" these are the "sanguine ensigns" of encountering armies in the sky; to "the weak vulgar" these are the portents of dreadful visitants; but to the poet, under the influence of the new science, there is awe inspired of beauty. Fear has been cast out by knowledge.

"The learned-one, curious, eyes it from afar,

Sparkling through night, a new illustrious star!",131

To him the colors of the rainbow are no longer an accepted mystery but a phenomenon explained by science, yet none the less marvelously beautiful. ${ }^{132}$ The great philosophers are not to him fools and knaves but men of transcendent genius; Bacon, Locke, Halley, and Newton are highly praised. This science, "from Liberty sprung", after years of misrepresentation, is at last coming into its own,-

"See Learning range yon broad aetherial plain,

From world to world, and God-like Science gain!

\footnotetext{
130 Canto I.

181 Canto III.

192 Canto VI.
} 
Ah! what avails the curious search sustain'd, The finish'd toil the God-like Science gain'd?

Sentenc'd to flames th' expansive wisdom fell, And truth from Heaven was sorcery from Hell. ${ }^{133}$

The Wanderer looks out on the world with the curious, inquisitive eyes of the new philosophers. The poet parts company with the scientist only where an enthusiasm for beauty divides itself from pleasure in the mere knowledge of truth. "The more she (Science)", said Lowell shrewdly, "makes one lobe of the brain Aristotelian, so much more will the other intrigue for an invitation to the banquet of Plato". ${ }^{134}$ And so The Wanderer, entering into the knowledge which science drew from the skies, gave to it the "impassioned expression" of poetry; for "poetry is the breath and finer spirit of all knowledge". ${ }^{135}$ Thus stands the poet-philosopher

"Calm, on the beach, while maddening billows rave;

$\mathrm{He}$ gains philosophy from every wave;

Science from every object round he draws;

From various Nature, and from Nature's laws". ${ }^{136}$

This philosophic pleasure in the beauty of the world is repeated in Henry Brooke's poem, Universal Beauty (1735). The ambitious poet seeks with "a daring unexampl'd" to "unfold the universal frame". The Newtonian system finds here once more an enthusiastic endorsement $;^{137}$ the earth has diminished to an atom in the universe of worlds $;^{138}$ the elasticity of the air, ${ }^{139}$ the revelations of the microscope- "nature's myriad minim race" - with their exquisite workmanship, ${ }^{140}$ the marvelous construction of the human frame $^{141}$ are made a part of the universal beauty. Swept on by the ardor of his poetic inspiration, Brooke prophesies new wonders and new beauties yet to be revealed.

133 An Epistle to Robert Walpole.

194 Latest Literary Essays, p. 182.

185 Wordsworth, Preface to the Lyrical Ballads, 1815.

18 To John Powell, Esq.

137 Bk. I-II.

$188 \mathrm{Bk}$. IV, 213.

$190 \mathrm{Bk}$. II, 334.

$140 \mathrm{Bk}$. IV, 115.

$141 \mathrm{Bk}$. IV, 1-14. 
"Think, should this curtain of Omniscience rise, Think of the sight! and think of the surprise!

Scenes inconceivable, essential, new,

Whelm'd on our soul, and lightning on our view". ${ }^{142}$

The poetic inspiration of astronomy found its fullest expression in Edward Young's Night Thoughts. The poet had left far behind him the satiric contempt of the Universal Passion, although even yet man is not a noble being. In the sustained and lofty eloquence of this poem, his fellow-beings forgotten, Young finds the new heavens of science a source of genuine poetic fervor. The firmament is for him "the garden of the Diety", 143 the study of which demands a religious spirit.

"Devotion! daughter of astronomy!

An undevout astronomer is mad". ${ }^{144}$

Young's primary purpose is to overthrow scepticism and this effort occupies the greater proportion of his work, but at times the poet overpowers the discursive theologian and looks with naked eyes upon "an infinite of floating worlds on yonder azure field", and with the microscope of imagination beholds "these twinkling multitudes of little life". It is in these passages that Young meets the new science and accepts from those whom he before had scorned the gratuitous riches of new ideas. Consciously or unconsciously, also, he accepts their point of view,-

"Mankind was sent into the world to see;

Sight gives the science needful to their peace". ${ }^{145}$

Once again has piety led a poet into an appreciation of science. The horizon, inconceivably enlarged by the telescope, has revealed not a god-less universe, as feared at first, but new beauty, new reason for belief in a Creator, new eause to "fall prostrate and adore". "Through the roof of the little theatre on which the drama of man's history had been enacted, men began to see the eternal stars shining in silent contempt upon their petty imaginings". ${ }_{146}$ This inspiring idea dawns upon Young's midnight musings. He says of our earth,-

142 Bk. V, 153-6.

$143 \mathrm{Bk}$. IX.

$144 \mathrm{Bk}$. IX.

145 Bk. IX.

${ }^{146}$ Stephens, Leslie, History of English Thought in the 18th Cent. I, 82. 
"This small nest,

Stuck in a corner of the universe,

Wrapt up in fleecy cloud, and fine-spun air."

And of proud man he demands, -

"What are thou? A beam,

A mere effluvium of his majesty;

And shall an atom of this atom-world

Mutter in dust and sin, the theme of heaven?"147

Young, sordidly ambitious and in many respects meanly selfish as a man, thus became the mouth-piece of new scientific ideas, and he, who had come early in life to scoff at all science, remained to pray in its very language. It is to be lamented that he never learned to follow his own preaching,-

"Man's science is the culture of the heart". ${ }^{148}$

And, finally, Akenside in the last year of this period published his Pleasures of the Imagination (1744), in which he finds the same source of inspiration. Again the poet's spirit soars through the heavens, "where reason points the way". ${ }^{149}$ The worlds on high, "the forms of atoms moving with incessant change the elemental round", "the melting rainbow's vernal-tinctur'd hues", all that the "spacious West and the teeming regions of the South hold in quarry" are to him material for poetry. And this poet, who despised the virtuoso with his studies of mites, his museums, his collections of rare plants, joined with Savage, Brooke, and Young to praise the work of science in other fields. He prayed, in his Hymn to Science (1739), for-

"The patient head, the candid heart,

Devoted to thy sway".

Those qualities were granted him in his later years when his medical studies led him more thoroughly into the new experimental philosophy.

Just a word is needed here to summarize what has been said of the appreciation of the new science among the poets. Through the lenses of the telescope the poet's eyes first saw the beauties of

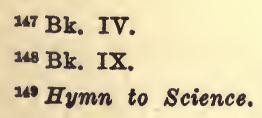


the new ideas, and piety first met astronomy on friendly terms. Slowly the new science was remoulding the poet's world; the humble creatures of earth were raised into dignity; and imagination first began to discover the marvelous that lurks in the commonplace. While appreciation is far less in bulk than satire, there is apparent a sure indication of the new attitude that was to come, when "the remotest discoveries of the Chemist, the Botanist, or the Mineralogist, will be as proper objects of the Poet's art as any upon which it can be employed". ${ }^{150}$

\section{III}

Another form in which science, old and new, enters into literature is in allusion and imagery. Obviously this is not a fair means to prove its rejection or to test the progress of its acceptance, for the out-worn figures cling to poetry long after belief has fallen away, but the gradual disappearance of the old and the steady growth of the new can be traced with tolerable clearness. This literary phenomenon will be illustrated here.

One finds the outgrown belief of the old science running through the years. References to healing by sympathy extend from Sir Kenelm Digby to Pope; ${ }^{151}$ the malignant stars shed their astrological influence through the same period;152 and the sun moves round the earth even in Pope's Pastorals. ${ }^{153}$ The "lawless comets" and the "meteor's fire" shine in countless lines; no poet failed to call attention to this striking natural phenomenon. But gradually men lost their superstitious fear, and when mathematics calculated the comets' course and the telescope identified them as stars, the old belief wholly died away,-

"Till from a comet she a star did rise,

Not to affright, but please, our wondering eyes". ${ }^{154}$

The music of the spheres was most difficult to silence, and sounded on long after belief had faded from the minds of both poet and

150 Wordsworth, Preface to the Lyrical Ballads, 1815.

151 Barker, Jane, To my Uncle C-, To Mr. C. B. Congreve, Epigram; Pope, Pastorals, Wk8., vol. I, p. 28.

152 Wycherley, To a Handsome Woman, On Chloris Rowe, The Fair Penitent, Act I, sc. 1.; Lady Winchelsea, The Hurricane, etc.

${ }^{158} \mathrm{Cf}$. Blackmore, Prince Arthur; Shenstone, Elegy, XI; Pope, Pastorals, vol. I, p. 23.

${ }^{154}$ Lee, Nathaniel, Panegyric on J. Dryden's Plays. 
reader. ${ }^{155}$ The Ptolemaic conception of the ten spheres circling the earth as their centre gave to English poetry imagery that has not yet entirely disappeared. It found expression through this period with surprising frequency. ${ }^{156}$ The milky way, like comets and meteors, was a stock image. Gradually the power of the telescope added a new meaning to it; rarely did a later poet fail to emphasize the fact that it is made up of a multitude of stars.

"Thus unseen the Stars i' th' Element, United, make the milky way". ${ }^{157}$

"One glittering thought no sooner strikes the eye, With silent wonder, but new wonders rise;

As in the milky way a shining white

O'erflows the heav'ns with one continued light;

That not a single star can shew his rays,

Whilst jointly all promote the common blaze". ${ }^{158}$

As the poets began to strike out new figures from the new science the imagery was caught up by various writers, even the phrasing being repeated to the point of monotony. The "rolling spheres", the "rolling orbs", and "the dancing maze" are found in practically every description of the sky, just as the "artillery of heaven" resounded for some years after Milton set it off. ${ }^{159}$ Unexpected theories find unexpected repetition. The Royal Society had listened to an explanation of the color of Damson plums as due to a small animal that lived on them. Shadwell ridiculed the idea in The Virtuoso. Sixty years later Thomson wrote,-

"The shining plum,

With a fine bluish mist of animals

Clouded." 160

And Henry Brooke, ten years afterward, gave expression to the same idea.

${ }^{155} \mathrm{Cf}$. Blackmore, Prince Arthur; Crowne, Pref. to Ambitious Statesman; Congreve, A Hymn to Harmony; Winchelsea, The Hymn.

$158 \mathrm{Cf}$. Otway, Venice Preserved, Act V, sc. 2; Congreve, Of Pleasing, The Birth of the Muse; Rowe, The Fair Penitent, Prologue; Arbuthnot, Know Thyself; Tickell, On the Prospect of Peace; Pope, Rape of the Lock, Canto II.

107 Wycherley, To a Lady.

168Addison, An Account of the Greatest English Poets.

${ }^{159}$ See Dryden, Burnet.

${ }^{160}$ Autumn, pp. 126-7, Crowell. 
"Or azure tribes that o'er the damson bloom, And plant the regions of the ripening plum". ${ }^{161}$

In like manner, Dryden coined a new figure in Annus Mirabilis, ${ }^{162}$ comparing the trade of a nation to the circulation of the blood. This was repeated in Jane Barker's A Farewell to Poetry, and much later in Edward Young's Reflections on the Public Situation.

The scientific apparatus appeared on a few occasions. One of the "last sayings of a mouse" 163 was to rejoice that there was "no Gresham engine my lean Corps to squeeze". Shenstone has "empty as the air-pumps drained of air". ${ }^{164}$ Congreve called vanity,-

"That Telescope of fools, through which they spy

Merit remote, and think the object nigh." "165

And Pope wrote,-

"As the gay Prism but mocks the flatter'd eye, And gives to ev'ry object ev'ry dye." 166

One of the most elaborate figures is by Andrew Marvell, To the King, on the use of the telescope in observing the spots on the sun.

The "sooty chemist" never attained to respectability in the poetry of this period. There are two ways in which he was presented; first, he was "feeding perpetual fires" in the vain hope of transmuting the baser metals into gold, secondly, he was a quack in concocting medicines. As an alchemist the following lines from Parnell's poem, To Mr. Pope, characterize him fairly,-

"The new machines in names of ridicule,

The grave frenzy of the Chymic fool."

The contempt for the chemist's medical skill is voiced by Lady Mary Wortley Montague in Town Eclogues (Saturday),-

"Ye cruel Chemists, what withheld your aid!

Could no pomatum save a trembling maid?

How false and trifling is that art ye boast!" ${ }_{167}$

161 Universal Beauty, Bk. I, 243-4.

1021.5.

${ }^{103}$ Anonymous.

164 The Progress of Taste.

${ }^{105}$ Of Pleasing.

${ }^{106}$ Essay on Satire.

${ }^{107}$ Town Eclogues, Saturday. 
The physician was usually associated with the apothecary as two rogues of a kind. As in comedy, the doctor vaunts the powers he does not possess. The literary men who were in the profession, such as Arbuthnot and Akenside, are silent regarding him. Samuel Garth is satirically resentful of the selfishness shown by the members of his own professional fraternity. But Blair, a layman, seeing men and women dying around him in spite of the professed powers of cure, writes defiantly.-

"Where is thy boasted implements of art?

. . . . nor fly nor insect,

Nor writhy snake, escaped thy deep research.

But why this apparatus? why this cost?

Tell us, doughty keepers from the grave,

Where are thy recipes and cordials now,

With the long list of vouchers for thy cures?

Alas! thou speakest not,- - the bold impostor

Looks not more silly when the cheat's found out" ${ }^{168}$

Of the scientists themselves the only one to whom the references are consistently laudatory is Newton. Lower, Sloane, Flamsteed, Lister, and Boyle are mentioned rarely. But it is to Newton that science was indebted for much of its dignity. The character of this great man was irreproachable,-indeed, commanded respect and honor. Even the spiteful Pope, who alone dared to east a slur upon him, said,-

"Nature and Nature's Laws lay hid in Night;

God said, Let Newton be! and all was Light." ${ }_{169}$

IV

Clearly the new philosophy did not find a ready or a full interpretation among the poets. The reasons for this are not readily discovered. In a sense poets are conservative; the poetic imagination cherishes the idols after they have been disowned by the philosophers. The raw, new facts of scientific discovery are not quickly surrounded by the necessary associations for a direct poetic expression of emotion. "The remotest discoveries of the Chemist, the Botanist, or the Mineralogist, will be as proper objects of the 
Poet's art as any upon which it can be employed, if the time should ever come when these things shall be familiar to us, and the relations under which they are contemplated by the followers of these respective sciences shall be manifestly and palpably material to us as enjoying and suffering beings". ${ }^{170}$ The comic and satiric representation of the new philosopher as a foolish, whimsical being, pursuing a kind of knowledge that was not "manifestly and palpably material" to the lives of men, no doubt delayed a genuine appreciation of the value of scientific work.

Furthermore, the poetry of this period is conspicuously emotionless. Poets looked into their heads, not into their hearts, when they wrote. They could not, therefore, be expected to understand and interpret "the deepest convictions of their age". This is the obvious reason that the great bulk of the verse of this time has become a dead letter; for "the imaginative literature of an age must express the genuine feelings of that age, or it will perish still-born". ${ }^{171}$ And, finally, there is always a temperamental element of discord, among the poets, between imagination and the scientific spirit.

170 Wordsworth, Preface to the Lyrical Ballads, 1815.

171 Stephens, Leslie, Hist. of Eng. Thought in 18th Cent., vol. II, p. 348. 


\section{CHAPTER V}

\section{The New ScIence and Prose}

In the work of Sir Francis Bacon "the English language first became the vehicle for scientific expression". His predecessors, "whether in science or philosophy, used the common language of learned men", which was of course Latin. ${ }^{1}$ But Bacon's influence was not immediately felt; the old ornate style with its "involved and artificial intricacies and copious classical quotations" continued in Burton, Browne, Milton, Fuller, Taylor, and others. Even in the Restoration period the English scientific writers did not have full confidence in their mother tongue; Willughby, Ray, Grew and Sydenham used Latin for their serious work; Newton's Principles first appeared in the same language, as did Burnet's Sacred Theory. A new simplicity and directness, however, may be found in Wilkins's New World in the Moon (1638) and later in Walton's Complete Angler (1655). This new prose art, "the clear and naked style approaching mathematical plainness", 2 was caught up by certain of the virtuosi and became the ideal of the Royal Society. With this model before them the new philosophers made a spirited effort to chronicle the new observations of science in the best literary form of the age. ${ }^{3}$ This effort lasted through the last forty years of the seventeenth century, and then gave way to a satiric exploitation by the group of brilliant Queen Anne wits. During these early years of the eighteenth century natural science developed its own direct, non-literary exposition and found only incidental representation in literary prose.

Three distinct phases, therefore, are to be found in the study of the new science and the prose of this period. First, there is an early effort to give an enthusiastic literary expression, beginning with Wilkins and ceasing practically with the end of the century; secondly, there is a satiric exploitation of the new interest reaching from John Eachard, the schoolmaster, to Ward, the London Spy; thirdly, there is an incidental representation in the philosophers, and a direct, non-literary exposition from the scientists themselves.

1 The Cambridge History of English Literature, vol. IV, p. 308.

2 Sprat, Thomas, History of the Royal Society, p. 113.

Elton, Oliver, The Augustan Ages, p. 419. 
The influence of the new study of physiology had early appeared in the titles, at least, of Burton's Anatomy of Melancholy and Towgood's Zootomia. But it was the astronomical studies, especially the new telescope and the recent discoveries of Galileo, that stimulated Wilkins, one of the eldest of the group at Gresham College, to write his New World in the Moon. He was, like the Duchess of Newcastle, bubbling over with "Phantasies", one of which led him to discuss with an appearance of scientific method the vexed question as to whether or not the moon was an inhabited world.

This writer was in full sympathy with the new scientific spirit, became a charter member of the Royal Society, and was active in its work. His book was made the butt of much ridicule during the succeeding years, especially his Proposition XIV where he discourses on the art of flying. This passage together with the introduction to Hooke's Micrographia made the new science responsible for these absurd claims for fifty years. But the style of the book is free from ornateness and approaches the "naked style" of the later scientists. There is little else of value in the work except as it shows that at this early date a man, thoroughly imbued with the new scientific spirit, attempted to give a literary expression to his observations.

Walton's Complete Angler, too, has a share in the new scientific movement; the expert speaks in him as well as the enthusiast. His knowledge of the different species of fish and insects is the same as that underlying the work of Willughby, Ray, and Grew. The power of ancient authority is still strong upon him; his most frequent references are to Aristotle, Pliny, Gesner, and Dubratius, and "vulgar errors" find a too ready acceptance with him." And yet he has looked with his own eyes, too; he has come to know thoroughly the habitats of the various kinds of fish; he has learned their anatomy, their ways of life, their methods of breeding. ${ }^{5} \mathrm{He}$ has come under the influence of Bacon's Natural History and is familiar with the work of the Royal Society. ${ }^{6}$ Walton himself had

\footnotetext{
4 The Complete Angler, p. 75, 97.

${ }^{5}$ Ibid. pp. 74, 97, 118, 159.

The Complete Angler, pp. 74, 97, 118, 159.
} 
made experiments after the manner of the new scientists. "I have seen," he says, "and may therefore affirm it"." There were some things that were required to have the confirmation of his senses to gain his belief. "And you are to know, that in Hampshire, which I think exceeds all England for swift, shallow, clear, pleasant brooks, and store of Trouts, they used to catch Trouts in the night, by the light of a Trout-spear, or other ways. This kind of way they catch very many; but I would not believe it till I was an eyewitness of it"'.8

This lover of sport understands the passion for curiosities that actuated the antiquaries. "These, to any that love learning, must be pleasing". The monument of Livy, "the humble house in which St. Paul was content to dwell", the bay-trees on the tomb of Virgil are pleasing and profitable to see. ${ }^{10}$ There is no astonishment, therefore, to discover that he is acquainted with the writings of Meric Casaubon and is familiar with the collection of rarities made by John Tradescant. ${ }^{11}$

This gentleman angler is an antiquarian and naturalist, living to a great extent under the domination of ancient authority and yet looking out upon rural England from the shade of his beloved sycamore or from the shelter of his favorite hedge with open eyes and with keen and accurate observation. "It may not be improper here to take notice, that in this, and several other parts of the book, the facts related by the author do most remarkably coincide with later discoveries of the most diligent and sagacious naturalists". ${ }^{12}$ There is a simplicity here that Sprat would praise; there is a quaintness, too, that gives distinction and personality; and in many places there is a realism struggling with ornateness for free expression. "But the nightingale, another of my airy creatures, breathes sweet loud music out of her little instrumental throat, that it might make mankind to think miracles are not yet ceased. He that at midnight, when the very labourer sleeps securely, should hear, as I have very often, the clear airs, the sweet descants, the

7 The Complete Angler, p. 96.

8 Ibid. p. 117.

Ibid. p. 34.

10 Ibid. p. 42 .

11 Ibid.

12 The Complete Angler, Editor, p. 123. 
natural rising and falling, the doubling and redoubling of her voice, might well be lifted above earth, and say, 'Lord, what music hast thou provided for the Saints in Heaven, when thou affordest bad men such music on earth" ". ${ }^{13}$ In Walton there is a partial fulfilment of Sprat's injunction to walk in nature as in a garden, and to taste of its plenty. "There I sat viewing the silver streams glide silently towards their centre, the tempestuous sea; yet sometimes opposed by rugged roots and pebble-stones, which broke their waves, and turned them into foam, and sometimes I beguiled time by viewing the harmless lambs; some leaping securely in the cool shade, whilst others sported themselves in the sun". ${ }^{14}$ Thus with the eyes of a scientist and the feeling of a poet, Piscator has combined the delightful qualities of accuracy and a sense for beauty. He would not have felt himself out of place among the group of scientists at Gresham College, nor would they have despised his fund of accurate information. Part scientist, part poet, and wholly an honest gentleman, Izaak Walton finds his early place in this new influence.

Aside from all controversies between sects, or between theology and philosophy, is the quiet and interested study by John Evelyn of the forest trees in England (Silva). The task was imposed upon Evelyn by royal request, but the genius of the man was such that the resulting book, instead of being a dull report, is yet alive with the pleasure of the writer. New knowledge has led to new interest; intimacy with nature has begotten enthusiasm; and a bulletin has been made a piece of literature.

The book deals with the familiar trees of the English forests and with those that have been and may be imported. The genera are treated upon a common plan,--kinds, care, habitat, and uses. The oak, elm, walnut, beech, ash, maple, sycamore, cherry, hazel, birch, and many others are described. The uniformity of the plan gives a touch of monotony to the book, yet a sense of freshness attends almost every description. At times the author injects an element of personal feeling into the passage. Of the holly he writes,- "Is there under heaven a more glorious and refreshing object of the kind, than an impregnable hedge of about four

18 Ibid. p. 26.

14 Ibid. p. 96. 
hundred feet in length, nine feet high, and five in diameter, which I can show in my now ruined Gardens at Sayes Court at any time of the year, glittering with its armed and varnished leaves? The taller standards at orderly distances, blushing with their natural coral: It mocks the rudest assaults of the weather, or hedgebreakers." 115

The new science may claim the content and inception of this book. Its purpose is practical, its method is scientific; if literature claims it all at the last the reason is that the pleasure of the author has been imparted through its pages to the reader. Silva is one of those rare instances where a delight is given by sugar-coating instruction. There is plenty of learning in the book; botanical names and Latin phrases abound. And there is the emotion of a discoverer and of a religious observer who wonders at the infinite handiwork of God. "And what Mortal is there so perfect an Atomist, who will undertake to detect the one thousandth part, or point, of so exile a Grain, as that in sensible rudiment . . . . . which brings forth the lofty Fir-tree and the spreading Oak? That trees of so enormous an height and magnitude, as we find some Elms, and Cypresses; that others hard as iron and solid as marble . . . . should be swaddled and involved within so weak and feeble a substance, without the least luxation, confusion, and disorder of parts! That when they are buried in the moist womb of Earth, which so easily dissolves and corrupts substances so much harder, yet this should be able in time to displace and rend asunder whole rocks of stone, and sometimes to cleave them beyond the force of iron wedges, so even to remove mountains! That our trees, like man (whose inverted symbol he is) being sown in corruption, rise in glory, and little and little ascending into an hard erect figure of comely dimensions, become a solid tower, as it were! And that which but lately a single ant could easily have borne to his little cavern, should now become capable of resisting the fury, and braving the rage of the most impetuous storms."

This early and splendid appreciation the new philosophy found in Walton and Evelyn. These two books are among the "renowned victories of peace". They have the merits of spontaneity, ${ }^{15}$ Silva, p. 386.

${ }^{16}$ Silva, p. 645. 
patriotism, and honesty. They sprang from a genuine scientific interest and from a "reason free and unpossest".

In that debatable land between prose as literature and as nonliterature lie such books as Sir Robert Boyle's The Sceptical Chemist, Occasional Reflections, and The Christian Virtuoso, Hooke's Micrographia, J. Childrey's Britania Baconica, Evelyn's Sculptura and Acetaria and Ray's Wisdom of God. Primarily, these books were all written for instruction, not for pleasure, and certainly were inspired by scientific research. There is, however, a conscious attempt to give them literary form. The three books of Boyle are, perhaps, his most nearly literary productions. The Sceptical Chemist is in the form of a dialogue between Eleutherius and Carneades on the latest chemical theories; it is a symposium on the general question as to whether there are three or five primary elements. Carneades, who speaks for Boyle, develops a general sceptical attitude of the old beliefs, and especially of the alchemical theory of transmuting the baser metals into gold. It was this attitude that "made a crisis in chemical theory". ${ }^{17}$ In Occasional Reflections there is a series of philosophical discourses on various subjects, some so unimportant and trivial as to furnish the basis of Swift's burlesque Meditations on a Broomstick. For examples, see Proposition I, Section 1, "Upon the Manner of giving Meat to his Dog", Proposition IV, Section 1, "Upon Paring a rare Summer Apple", Proposition II, Section 2, "Upon his Making a Fire", Proposition IX, Last Section, "Upon the finding of a Horse-shoe in the High-way". The Christian Virtuoso is really a defense of the new philosophy against the accusation of scepticism; its original purpose was "to prove a man may be a good christian and at the same time an experimental philosopher". ${ }^{18}$

Hooke's Micrographia is a series of philosophical reports resulting from his experiments. The style is clear and terse and aims to meet the ideal of the scientists. There is enthusiasm here, also, born of discovery; Hooke feels himself a pioneer making straight the way for truth. But the original purpose was to impart information, to explain natural phenomena, such as the essence of fire, the cause of color, etc. Childrey's Britania Baconica,

17 Elton, Oliver, The Augustan Ages, p. 160.

18 The Christian Virtuoso, Introduction. 
as its title implies, was written to earry forward the work of reconstructing the natural history of England after Bacon's manner. It is filled with the author's observations of curiosities and phenomena in Staffordshire. There is, however, no attempt at style; for the most part it is a mere catalogue. For the reader of today who knows Gilbert White's Natural History of Selborne it is dry and stupid. The Sculptura and Acetaria of Evelyn have almost as much right to be classed among the works of literature as Silva. But they are manifestly inferior to that book and illustrate no new literary expression of science. Their titles indicate with sufficient clearness the fields of interest out of which they were harvested. Ray's Wisdom of God, also, has some claim to attention. Just as certain poets, filled with piety, found new emotion in the revelations of astronomy, just as Newton sought to prove the existence of a God from his new system of the world, so the observers of the structure and relationship of plants and animals, the discoverers of the wonderful mechanism in even the most minute forms, found reason to proclaim the "wisdom of God". Of this number was Ray, the botanist. The purpose of his book was primarily theological and it falls into its proper place in the development of the ideas of the systemists, who have as their eloquent spokesmen, Shaftesbury, Bolingbroke, and Pope. ${ }^{19}$

English literature in any narrowed sense can hardly claim the prose works of the greatest scientist of the period, Sir Isaac Newton. The Principia, his most important work, was written originally in Latin according to the custom of learned men of his time. Optics has no pretensions to literary expression; it is merely a bald statement of experiments and demonstrations. The famous Letters to Bentley are less cold and rigid, but are directed toward theology, where "he argues an intelligent agent from the discovered motions of the planets". Newton passed over wholly within the realms of theology in such a work as Observations on the Prophecy of Daniel. The new science, of course, followed him thither, for it had become a part of his habit of thought. And

\footnotetext{
10 The most complete investigation into the problem of the deists was made by Joseph Butler in his Analogy (1736). The new science contributed to this whole theological discussion (1) the search for natural causes, and (2) the new conception of the physical world. Butler's Analogy is a criticism on the attempts to prove by a posteriori methods the existence of a God.
} 
here, too, he is raised by religious contemplation to something like emotional literary expression, where the "pressure of an immense brooding mind can be felt". ${ }^{20}$ "Did blind Chance know there was light, and what was its refraction, and fit the eyes of all creatures, after the most curious manner, to make use of it?"21 But this great mind never gave in any sense an adequate literary expression to those lone voyages on the seas of thought. His work was, however, incalculably stimulating and his personality gave dignity and seriousness to scientific research.

There is another class of books of which mention must be made; namely, the books of travel. Ray's Account of his Journeys on the Continent, Lister's Journey to Paris, burlesqued by William King in his Journey to London, Dampier's Voyages, Thoresby's Autobiography, and others, contain the same spirit of inquiry that impelled the new philosophers in their microscopical and telescopical investigations. As the scientists were sent forth into all the world from Solomon's House in The New Atlantis, so, in real life, did the new philosophers go among strange peoples, Ray and Willughby to the continent, Browne to Iceland, Lister to Paris, Sir Robert Moray to Hungary, Halley to South America, Thoresby to Holland. Books of prose resulted from these excursions, that afford stores of information for the student of social and political history, but were never intended as literary productions.

II

The new science, after an early appreciation, fell among the thorns of satire. The "Wits and Railleurs" in prose attacked without mercy, yet with more discrimination than the poets. There is keen and cutting satire in The Grounds and Occasions of the Contempt of the Clergy (1670), by the schoolmaster, John Eachard. He finds fault with the new philosophy for its evil effect upon the students who are preparing for the ministry. He does not claim that it gives them wrong ideas. "Neither shall I here examine which Philosophy, the Old or the New, makes the best sermons. It is hard to say, that exhortation can be to no purpose, if the preacher believes that the earth turns round! or that his

${ }^{20}$ Elton, Oliver, The Augustan Ages, p. 59.

21 Observations on the Prophecy of Daniel. 
reproofs take no effect unless he suppose a vacuum. There have been good sermons, no question! made in the days of Materia Prima and Occult Qualities; and there are, doubtless, still good discourses now, under the reign of Atoms". But the new science, he declares, has made the young students pedantic. "And, for the most part, an ordinary cheesemonger or plumseller, that scarce(ly) ever heard of a university; shall write much better sense, and more to the purpose than these young philosophers, who injudiciously hunting only for great words, make themselves learnedly ridiculous". ${ }^{22}$ And lastly, he asserts, the young preacher who has filled his commonplace book with similitudes from "the old philosophy, and Ptolemy's system of the world," would best "go a-gleaning for new ones; it being, nowadays, much more gentle and warrantable to take similitudes from the Man in the Moon than from solid orbs; for though few people do absolutely believe there is any such Eminent Person there; yet the thing is possible, whereas the other is not". ${ }^{23}$ Eachard's criticism was no doubt justified by facts, for many students must have left the university like "the pert young Soph", with his memory filled with the canting terms of the new philosophy and his mind devoid of any clear ideas. Of such were the pedants, who lacked the humility of the true scientist and professed boldly a knowledge which they never possessed.

The irrepressible William King wrote numerous satires on the new science. His Transactioneer, "a burlesque satire of some merit", ${ }^{24}$ has already been mentioned. Dr. Johnson thought the attack was aimed at Sir Hans Sloane, who_was then Secretary of the Royal Society. ${ }^{25}$ The character of King's attack may be determined from his Miscellanies. In the first essay, Animadversions on the Pretended Account of Denmark, he ridicules the Danish university. There are, he says, splendid buildings and numerous students, the two prime necessities for a great school. But of scholarship, of great teachers and sound learning he has nothing to

${ }^{22}$ Arber's Reprints, vol. III, p. 262.

28 Ibid. p. 263-4.

${ }^{24}$ Swift's Wk8. vol. V, p. 154, note.

${ }^{25}$ Johnson's Wks. X, p. 32. 
say. ${ }^{26}$ He derides the discoveries of Bartholinus and Borrichius. ${ }^{27}$, His Journey to London gives a pretended account of his visit to the virtuosi there. "I heard of several Persons that had great Collections of Rarities, Pictures, and Statues"'.28 Among these rarities are the following:-A Roman glass, a rummer of two quarts, "a copy of writing said to be the Devil's writing", a Miller's thumb, several sorts of tadpoles and sticklebacks. ${ }^{29}$ He holds a conversation with certain ones of the experimenters. "I had several Discourses with Mr. Muddifond, about an old Cat and a young Kitling in an Air-Pump, and how the Cat died after 16 Pumps, but the Kitling surviv'd 500 Pumps". ${ }^{30}$ He received as souvenirs from these virtuosi, Mr. Muddifond and Mr. Goodenough, two human hearts. In the Tower he finds a whole menagerie, "Lyons, Tygers, Catamountains, two Owls, and a calf-skin stuft". Being himself a virtuoso, he sees nothing of interest in the Royal Mint except "a coin from Palmyra". ${ }^{31}$ Mr. Shuttleworth shows him such great curiosities as "a Stone out of Scotland with the names of all those killed at chevy Chase", "the skin of a Cap Ass, some Land Snails, a thin Oyster, some papers of Swammerdam with Figures of Tadpoles, an Egyptian Rattle, and great Cases full of Playthings from France". Connected with these virtuosi are the quack doctors whose advertisements "covered the walls everywhere about the town". Here is a specimen; "AQUA TETRACHYMAgogon, Rear, Try, Judge, and Speak as You Find". ${ }^{32}$ This traveller also visits the famous Chelsea Gardens and inspects the medicinal plants there. ${ }^{33}$ At the close of the Journey is an apology for not furnishing the reader with drawings of "the Wren's Nest, the Stickleback, the Two Snails, and the two Grasshoppers". "My Bookseller said the Graver was out of the way". ${ }^{34}$

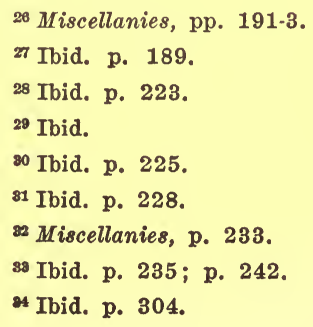


In the dialogue, called Affectation of the Learnied Lady, there is portrayed a comic character, who is the equal of Valeria in the Basset-Table and Lady Science in The Humours of Oxford. Calphurnia keeps on her table, instead of toilet articles, "the works of Jansenius, Descartes, Casaubon, Kircher, with such like Authors, and Manuscripts innumerable".35 "I was so visited in the Morning", she explains, "by the Virtuosi, Criticks, Poets, Booksellers; so taken up with my Correspondence with the learned both at home and Abroad, that I had little time to talk with my Milliner, Dresser, Mantua-Maker, and such illiterate People". ${ }^{36}$ So greatly absorbed is she in these scientific interests that she "keeps a calling day once a fortnight for the ladies, but everyday for the Virtuosi". ${ }^{37}$ The Dialogues of the Dead ${ }^{38}$ is a satire on the famous astrologer, Lilly, and Modern Learning on the study of insects. The former does not touch upon the new science; the tone of the latter has long since grown familiar. Moderno appears bespattered with filth, and, on the enquiry of Indifferentio, accounts for his condition by saying he has been in a ditch in search of knowledge; for "there has been more true Experience in Natural Philosophy gather'd out of Ditches in this latter Century than Pliny and Aristotle were Masters of both together". ${ }^{39}$ Although the spring has not fully come, he has gone out into the fields because he has grown weary of the "winter-sports within Doors, as Rat-Catching, Mouse-fleying, Crevice-searching for Spiders, Cricket-dissecting, and the like". ${ }^{40}$

"Indifferentio,-Pray, Sir, have you not some Diversions peculiar to the summer?

Moderno,-Oh! Yes! infinite! Maggots, Flies, Gnats, Bugges, Chaffers, Humble-Bees, Wasps, Grasshoppers, and in a good year Caterpillars in abundance . . . . Gredartius and Swammerdam became Eminent for this Business". ${ }^{41}$

King's attitude is that of comedy; he exploits the scientific in-

${ }^{35}$ Ibid. p. 304 .

${ }^{a 6}$ Ibid. 309.

${ }^{87}$ Miscellanies, p. 309.

28 Ibid. p. 314.

? Ibid. p. 334 .

${ }^{40}$ Ibid. p. 326.

11 Ibid. p. 326-7. 
terest as a humor. There is, however, no bitterness in his attack. His aim is to raise a laugh, and he does it at the expense of the worthy and the unworthy. One looks in vain for any serious treatment of the subject in his work; yet there is a single passage in the Dialogues of the Dead, which seems to contain as definite a statement of King's real attitude as can be found. "Consider further, That men of true Learning will always be Honour'd whilst their Mimicks are despised". ${ }_{42}$

Of the same character as King's are the satires, or Amusements, of Thomas Brown. Apothecaries, surgeons and physicians are all ridiculed in Amusement $X$. A boy has swallowed a knife and these wise men have met in consultation as to the best method of removing it from his stomach. The apothecaries advise certain quack emetics; the surgeons say eut him open; the physicians suggest an effective method by the use of a loadstone, but too indecent to explain. Brown does not hesitate in his satire to become personal; it was "my particular Friend Dr. W-dw-rd (Woodward) who first mentioned the loadstone, and he is no quack I assure you". ${ }^{43}$ There is also a satiric comment on Lilly and astrology; Lilly is the chief "proficient in the Celestial Gimcracks". The quackery in astrology Brown understood full well, and has here given it the kind of treatment it deserved.

The amplest satire on the virtuosi occurs where Brown arrives at "The Philosophical or Virtuosi Country". "This Country of Experimental Philosophy is very amusing, and their Collections of Rarities exceeds that of John Trudusken (Tradescant), for here are Galls of Doves, the eye-teeth of flying Toads, the eggs of Ants, and the eyes of Oysters. Here they weigh the Air, measure heat, cold, dryness, and humidity-great discoveries for the public advantage of Mankind. Without giving our selves the trouble of making use of our senses, we need only cast our eyes upon a weather glass to know if 'tis hot or cold, if it rains, or is fair weather"."44 In this country the "Contemplative Gentlemen" occupy themselves "with dissecting atoms, or mites in cheese, with transfusing blood from an Ass to an astrological quack, from a sheep into a bully, or

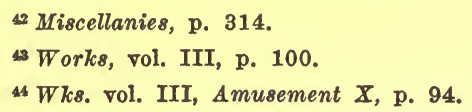


from a fish into an exchange woman". They are continually "chewing the cud of Burnet's Sacred Theory", or quarreling incessantly over the opposing theories of Aristotle and Descartes, Cardan and Copernicus, William Penn and Christianity. Acidists and Alkalidists, or "putting a period to the abstruse debates between the engineers and mouse-trap makers". ${ }^{45}$

The satire of Brown is bright and keen. As usual with writers of his stamp, he makes no discrimination between pretense and true worth. Lilly and Cooley are boldly attacked by name as exponents of quackery in his scornful assault on astrology; but there is no praise for the splendid work of Boyle, Halley, and Newton among the virtuosi. Brown avoids seriousness and generally with success hides his real attitude behind the mask of boisterous laughter. He has, however, once at least come near the true mark and expressed with shrewdness and wit the secret of the misunderstanding between the new philosophers and the men about town. "The Vertuoso despises the Rich for making such a bustle about so foolish and pale-faced a metal as Gold. The Rich laugh at Learning and learned Men, and cry, A Fig for Aristotle and Descartes". ${ }^{48}$ Brown saw with surprising clearness that there were these two points of view, these two standards of value, which led to a natural and mutual misunderstanding.

Dean Swift, besides his efforts to defend Sir William Temple against the Moderns, found other occasions to scoff at the new philosophers. In his Art of Growing Poor, he ridicules those foolish beliefs that were clinging like parasites to the new science and which made it an easy prey for satirists,-- "the Philosophers' Stone, and Perpetual Motion, could not miss being among the principal Embellishments of this work, any more than the Art of Flying, which set so many of the Virtuoso's of the last Age upon their Tiptoes"..47 Mathematical calculations applied to astronomy are ridiculed in A Tripos, the pretended speech assumed to have been delivered at the Commencement, University of Dublin, July 11, 1688. The virtuosi "aimed at here are Ashe and Molyneux who had made so much of a predicted eclipse of the sun in the Philosopicical

45 Ibid. p. 95.

46 Ws. III, p. 83.

4 See A New Project. 
Transactions, 1684". So exactly is the actual moment of eclipse calculated, "as sure as a gun", that the virtuosi arrange their minutest affairs to suit the coming darkness. In the conclusion to the piece Swift predicts a retaliation upon himself for his strictures. "The virtuosi will set their brains a-work for Gimcracks to pull my eyes out . . . . And the Astronomers wont allow me one good star nor inform me when the sun will be totally eclipsed, that I may provide myself with candles". ${ }^{48}$ In the Parallel a virtuoso is to get a reward of five thousand pounds "for inventing perpetual motion". ${ }^{49}$ As mentioned before, Boyle's Occasional Reflections is burlesqued in a Meditation on a Broumstick. ${ }^{50}$

Swift's severest arraignment of the new science is to be found in Gulliver's travels. Upon the arrival of the traveller among the Brobdignagians, he finds the king of that courtry to be a great mathematician, who has drawn around him a company of philosophers. Gulliver is at once examined by these learned men and classed as a "lusus naturae", "a determination exactly agreeable to the modern philosophy of Europe, whose professors, disdaining the old evasion of occult causes whereby the followers of Aristotle endeavoured in vain to disguise their ignorance, have invented this wonderful solution of all difficulties, to the unspeakable advancement of human knowledge." 51 As mementos Gulliver brings back to England four wasps' stings, three of which he gives to Gresham College. ${ }^{52}$ The general comment on the learning of these people is that they know only the sensible and useful things, which among the virtuosi would be little esteemed..$^{53}$

The inhabitants of Laputa, or the Flying Island, are greatly given to the speculative sciences. With them everything takes form according to the principles of mathematics or music; they believe in judicial astrology; they have the latest "odd notions", regarding the celestial bodies,-such as, the earth approaches the sun, the

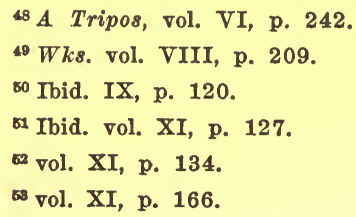


tail of a comet has brushed the earth, and the sun is losing its heat. The motions of the island are guided by means of a great magnet located at its centre. As a consequence of all their speculations these people are "dexterous enough upon a piece of paper", but are clumsy, awkward and unhandy "in the common actions and behaviours of life". ${ }^{54}$ At the "Grand Academy of Lagado" are found the projectors, who have discovered the means of drawing sunbeams out of cucumbers, who have conceived the idea of ploughing with hogs and of using spiders to weave silk, who write books by machinery in an universal language. The whole passage, though imitated in form from Rabelais, has for its substance the recent projects of the Royal Society.

Swift seemed to find himself a misfit among the new ideas, as elsewhere. So thoroughly has the satiric mood colored all his thought, so successfully does he screen his real self behind ironical raillery, that one is never sure of knowing what his mind truly is. His manner of dealing with the new science is well expressed in Gulliver's Travels (II), where Gulliver finds the ladies among the Brobdignagians so ugly. By applying a magnifying glass, he says, "the smoothest and whitest skins look rough, and coarse, and ill-coloured".55 Swift has applied his satiric magnifying glass to the work of the new philosophers. "I confess I value the opinion of the judicious few", he has written in what appears to be a serious manner, ". . . . . but for the rest, to give my judgment at once, I think the long dispute among the philosophers about a vacuum, may be determined in the affirmative that is to be found in the Critick's head.' ${ }_{58}$ And, again, when Glubbdrubdrib has called up the spirit of Artistotle, that philosopher is made to say of the new scientific beliefs,- "New systems of nature were but new fashions, which would vary in every age; and even those who pretend to demonstrate them from mathematical principles, would flourish but a short period of time, and be out of vogue when that was determined". ${ }^{57}$ In his defense of Temple, he pretended to ridicule only the absurdities that clung to the new science, but he

${ }^{54}$ Swift's Works, vol. XI, p. 198.

${ }^{55}$ Swift, Wks. vol. XI, p. 112.

${ }^{6 B}$ A Tritical Essay, vol. IX, pp. 128-9.

or Gulliver's Travels, III, vol. XI, p. 241. 
seems at last to have found it practically all absurd. A splendid work was being done in astronomy, and yet to Swift it amounted to no more than the calculations of an eclipse to avoid eating in the dark. Apparently he looked upon the new philosophy with the same jaundiced eyes with which he saw the affairs of church and state and society.

A study of Swift leads directly to a consideration of the Martinus Scriblerus Papers, the fragmentary production of the famous Scriblerus Club. The members of the Club were Swift, Pope, Arbuthnot, Gay, and Parnell.58 Their design was "to have ridiculed all the false tastes in learning, under the character of a man of Capacity enough, that had dipped into every art and science, but injudiciously in each". ${ }^{59}$ With such a purpose before them no appreciation of the good points can be expected. The inevitable injustice of satire will be found;-namely, the exaggeration of weaknesses and absurdities and the suppression of good qualities.

The problem of authorship of the Scriblerus Papers has never been fully resolved; it seems a fair position, however, to assume the work a collaboration. The wit is surely the combined brilliance of the triumvirate, Arbuthnot, Swift, and Pope. The character of Martinus Scriblerus himself, attributed to Arbuthnot, is a comprehensive travesty on the philosophers. Everything about him,-parentage, time of birth, infantile precocity,-foretells his philosophic greatness. "This day, my Friends", says the proud father, Cornelius Scriblerus, "I purpose to exhibit my son before you; a child not wholly unworthy of Inspection, as he is descended from a Race of Virtuosi". ${ }^{60}$ This youth quickly becomes a prodigy. He is trained to be a physician and exhibits all the quackery of medicine, ${ }^{61}$ and all the wild fancies of a projector. ${ }^{62}$ With irrepressible energy he "seeks to disprove Sir Isaac Newton's theory of gravity and Mr. Halley's of the Variations". ${ }^{63}$ "He taught the way to many Modern Physicians, to cure by Intuition, and to

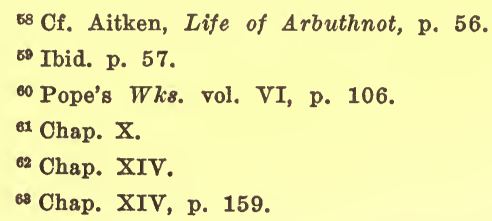


others to cure without looking on them at all. He projected a Menistruum to dissolve the Stone made of Dr. Woodward's Universal Deluge Water. His was also the device to relieve consumptive or asthmatic persons by bringing fresh air out of the Country to Town, through pipes of the nature of the Recipients of AirPumps". ${ }^{64}$ Besides all this he had discovered a quadrature of a circle, the cause of gravity, a vacuum, "the palpability of colours", "perpetuum mobile", a flying engine, and "how much the inhabitants of the moon eat for supper". He has at last found the correct theory of the deluge. His means for determining the longitude was sufficiently ingenious to make him famous; i. e., "to build Two Poles to the Meridian, with immense Light-houses on the top of them; to supply the defect of nature, and to make the Longitude as easy to be calculated as the Latitude". ${ }^{65}$

All the vagaries of the new science are here, and all its activities are turned to ridicule. Discoveries, inventions, travels, medicine, surgery,-whatever entered into the minds of the virtuosi is laughed to scorn. True tastes suffer with the false. Martinus Scriblerus, like Sir Nicholas Gimcrack, embodies the new philosophic humor. He leaves to the Royal Society "the privilege of catoptrical cookery" ;" he visits "the reverend Mr. Flamsteed, who is the legal officer to look after the luminaries". ${ }^{67}$ "Whatever he judged beneficial to mankind, he constantly communicated (not only during his stay among us, but ever since his absence) by some method or other in which ostentation had no part. With what incredible modesty he concealed himself, is known to numbers of those to whom he addressed sometimes Epistles, Advice to Friends, Projects of First Ministers, Letters to Members of Parliament, Accounts to the Royal Society, and innumerable others' ${ }^{68}$ Here again is an exploitation of a humor, wherein all suffer alike, the good and the bad, the wise man and the fool.

Arbuthnot's wit found attractive material in the new philosophy. There is a burlesque on scientific research in his Learned

\footnotetext{
44 Pope's Works, vol. VI, pp. 159-60.

${ }^{65}$ Ibid. vol. VI, p. 159.

Swift's Wks. vol. XVI, p. 178.

or Ibid. 179.

68 Pope's Wks. vol. VI, p. 161.
} 
Dissertation on a Dumpling. ${ }^{69}$ "I received", he asserts, "this part of the history of pudding from old Mr. Lawrence of Wilsden Green, the greatest Antiquary of the present Age". ${ }^{70}$ The account that follows is full of good fun and is free from all bitterness. A Letter to the Students of both Universities is a scurrilous attack on modern scientific controversies. All kinds of study are diseases that manifest themselves in varying forms. One interest develops the vapors, perhaps, and produces "a deal of speculation upon Circles, and the squaring of Comets, the Courses of Heavenly Bodies, Vortex's, the Longitude, perpetual Motion." "A1 "All this show, when expressed on Paper, still betrays its original to be mere Flatus, Air, Wind, and Vapour." 72 The Congress of the Bees is another burlesque on the reports to the Royal Society. It purports to be in part a study of those insects made by Sir John Mandeville, found recently in a manuscript preserved at Gresham College. A severe and unkindly criticism is made of Dr. Woodward in The Sickness and Death of Dr. Woodward, ${ }^{73}$ and the Life and Death of Don Bilioso de L'Estomac. ${ }^{74}$ The untenable theories of Woodward are attacked in An Examination of Dr. Woodward's Account of the Deluge ${ }^{75}$ and The Longitude Examin'd. ${ }^{76}$

All of the satire attributed to Arbuthnot, with the exception of The Death of a Late Right Reverend-(Gilbert Burnet), is goodnatured. There is in it neither the bitter irony of Swift nor the cruelty of Pope. As a matter of fact, the author was himself one of the new philosophers, a physician and a member of the Royal Society. He even presented before that learned body a serious discussion of Mathematical Learning. His quarrel with Woodward, therefore, was one of theories merely; they were alike in sympathy with the new philosophy. But Arbuthnot saw scientific interest becoming a fad, saw untenable theories foisted upon it. "To hunt after comets, and catch them by the tail; to reform the

69 Arbuthnot, Wk8. vol. I, p. 59.

70 Ibid.

71 Ibid. vol. II, p. 109.

72 Ibid. vol. II, pp. 109-10.

73 $W k 8$. vol. II, p. 464.

74 Ibid. p. 183.

${ }^{75}$ Ibid. p. 196.

${ }^{76}$ Wks. vol. II, Supplement, p. 66. 
Architecture of the-world; and make Creation look a little more mathematical; to discover the Globe of 'Earth to be only a large work in a kind of pastry, and that the Crust parting by Excess of heat, and dropping Piecemeal into the Liquor enclos'd, occasion'd the Deluge; and that the Stars, which the Vulgar look upon, as so many Lights hung out in a dark Passage, are really so many populous Countries, containing some Millions of Acres in Terra Firma,--are the most ingenious Amusements in the World". ${ }^{77}$ It was this making an amusement only out of scientific research which he desired to satirize. But he was possessed of the spirit of wit, so that whatever he wrote was sharp and keen. And yet at bottom he was sensible and tolerant, "the wisest, wittiest, most sensible man of his age".

More satirical exploitation awaited the new science on the appearance of the famous periodicals of the early eighteenth century. The Tatler has devoted several papers to this humor. Number 119 , for instance, deals with the new discoveries of the microscope. It seems to be at the beginning a true appreciation of the work of the investigators, but soon the whole interest is turned into ridicule by a subtle irony. These glasses have revealed a new world, have "opened a new and inexhaustible Magazine of Rarities, more wonderful and amazing than any of those which astonished our forefathers." "There is not the least particle of matter which may not furnish one of us employment for a whole eternity". Daily great crowds flock to witness the dissection of a mite or to see the skeleton of a flea. No longer can the "opening of a dog, to observe the circulation of the blood" astonish, since it is possible to be "present at the cutting of one of those little animals which we find in the blue of plums". As in satiric verse, the contempt for those men who spend their time with contemptible vermin of nature finds expression here.

The point of the criticism is made clearer in Tatler 216. "I would not discourage any searches that are made into the most minute and trivial parts of Creation. However, since the world abounds in the noblest fields of speculation, it is methinks, the mark of a little genius to be wholly conversant among insects, rep-

${ }^{7}$ Arbuthnot's Wks. vol. II, p. 109. 
tiles, animalcules, and those trifling rarities that furnish out the apartment of a virtuoso". Here is the gist of The Tatler's attitude; to dig in the muck when the heavens offer so much better and nobler objects for contemplation convicts a man of meanness, makes him a fit subject for satire. And such a man is Sir Nicholas Gimerack, who has stepped out of Shadwell's The Virtuoso into the pages of The Tatler. But he has fallen into a mortal sickness and on his deathbed has made his will, which is here appended. "I, Nicholas Gimcrack, being in sound health of mind, but in great weakness of body, do by this my last will and testament bestow my worldly Goods and Chattels in the manner following; Imprimis. To my daughter Elizabeth, my Receipt for preserving dead Caterpillars. Also my preparation of winter may dew, and embryo-pickle.

Item. To my little daughter Fanny, three Crockodile's eggs. And upon the birth of her first Child, if she marries with her mother's consent, the nest of a Humming-Bird.

Item. To my eldest Brother, as an acknowledgement for the lands he has vested in my son Charles, I bequeath my last year's collection of Grasshoppers.

Item. To his Daughter, Susanna, being his only Child, I bequeath. my English Weeds pasted on Royal paper, with my large Folio of Indian Cabbage. Having fully provided for my nephew Isaac by making over to him some years since, a horned Scarabaeus, the skin of a rattlesnake, and the mummy of an Egyptian King, I make no further Provision for him in my Will.

My eldest son John, having spoken disrespectfully of his little Sister, whom I keep by me in Spirits of Wine, and in many other instances behaved himself undutifully toward me, I do disinherit and wholly cut off from any part of this my personal estate, by giving him a cockle shell.

To my second son Charles, I give and bequeath all my Flowers, Plants, Minerals, Mosses, Shells, Pebbles, Fossils, Beetles, Butterflies, Caterpillars, Grasshoppers"'-. ${ }^{78}$

A few days later appeared a letter to The Tatler from Lady Gimcrack, newly made a widow. ${ }^{79}$ She is grateful for the mention

78 The Tatler, Number 216.

7bid. Number 221. 
of her lamented husband in the pages of The Tatler, and relates briefly how the symptoms of this strange scientific humor, which possessed him so completely, first manifested themselves. Sir Nicholas bought a microscope, was elected a Fellow of the Royal Society, and never afterwards talked in a manner that other people could understand. Not even the members of his own household could understand him. He was wont to wander about with his pockets full of moss and pebbles, and once ran five miles in the chase of an "odd-colored butterfly". In his very last moments, he remembered a flea which he had kept imprisoned for the purpose of making observations, and in imitation of the ancient Romans who freed their slaves with their dying breath, he asked that it might be given its liberty. He was ever more industrious "to improve his mind than his estate."

This was the same kind of virtuoso who was reported to have been set the task in the reign of Charles II to people Ireland with frogs. ${ }^{80} \mathrm{He}$ caught one, and started. out with it in a boat, but found it grew faint and seasick with the first breath from those shores. By waiting until the wind blew from the open sea, the virtuoso managed to land with his precious charge. It soon expired, however, after touching Irish soil.

Why, one is inclined to ask, is there no appreciation of the good work done by the virtuosi? Why all this burlesque on the absurdities of the new movement? The time was not yet come for commendation, but it was near at hand. Addison, who wrote these Tatler papers on the new science, had a lesson to teach, a folly to correct. Here is the point he has been emphasizing all the time,-"There is no study more becoming a rational creature than that of natural Philosophy; but, as several of our modern virtuosi manage it, their speculations do not so much tend to open and enlarge the mind, as to contract and fix it upon trifles". 81 When this point has been pressed home to his satisfaction, he will turn, as did the pious poets, to those nobler aspects of the new interest.

The Spectator, also, must have its fling at the new philosophy. Physicians, says Addison in Spectator 21, have "taken to amusing themselves with the stifling of cats in an air-pump, cutting up

80 The Tatler, Number 236.

Inid. 
dogs alive, or impaling insects upon the point of a needle for microscopical investigations; besides those that are employed in the gathering of weeds and the chase of butterflies; not to mention the cockle-shell merchants and spider-catchers". The works of Sir Isaac Newton occupy a place beside the French romances on the shelves in the library of the learned lady. ${ }^{82}$ The evil effect which the new science may have upon the minds of young women is explained in a letter from a man who has two nieces deeply imbued with the virtuoso spirit. These two young women talk of "the magnetical virtue of the loadstone rather than the best way to make a sack-posset"; they scorn to express themselves in other than Latin derivatives; and, finally, they will not let their uncle "smoke one pipe in the quiet" of ignorance. ${ }^{83}$ With the appearance of seriousness The Spectator suggests that a fitting employment for the Royal Society would be a new natural history. ${ }^{84}$ It is claimed, however, that these papers have usurped the original purpose of the new scientific interest; namely, "to draw men's minds off from the bitterness of party'" ${ }^{85}$

But in spite of the "Chymist's jargon", the quacks and charlatans in medicine, and the useless studies of insects, The Spectator finds much to admire in the new philosophy. Bacon, Boyle, and Newton are mentioned with praise, ${ }^{86}$ and the new "theories of the earth and the heavens" have "gratified and enlarged the imagination". ${ }^{87}$ The studies in anatomy have revealed how "fearfully and wonderfully the human frame is made". ${ }^{88}$ Addison caught a glimpse of that new and revolutionizing idea of the new science, that the earth is a mere speck in space, that man is but "an atom of this atom world". "In the same manner, when I considered that infinite host of stars, or, to speak philosophically, of suns, which were then shining upon me, with those innumerable sets of planets or worlds, which were moving around their respective suns; when I still enlarged the idea, and supposed another heaven of suns, and

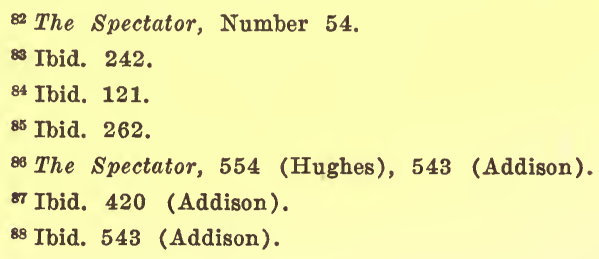


worlds rising still above this which we discovered, and these still enlightened by a superior firmament of luminaries, which are planted at so great a distance, that they may appear to the inhabitants of the former as the stars do to us: In short, whilst I pursued this thought, I could not but reflect on the little insignificant figure which I myself bore amidst the immensity of God's works. Hugenius carries this thought so far, that he does not think it impossible there may be stars whose light is not yet travelled down to us, since their first creation"'.89

The Guardian is for the most part an echo of the ridicule in The Tatler and The Spectator. Jack Lizard returns from the university a philosophical pedant. ${ }^{90}$. The wild schemes of Whiston and Ditton for finding the longitude, ${ }^{91}$ Wilkins's art of flying, ${ }^{92}$ and the observations of the habits of insects ${ }^{93}$ are satirized in a goodnatured fashion. Berkeley has written an amusing travesty on the Cartesian theory that "the soul of man stands tiptoe on the pineal gland".94 Steele has given with considerable detail the character of a virtuoso who is piqued because his merits are not honored.

"Sir,-I am a very great scholar, wear a fair wig, and have an immense number of books curiously bound and gilt. $I$ excel in a singularity of diction and manners, and visit persons of the first quality. In fine, I have by me a great quantity of cockle-shells, which, however, does not defend me from the insults of another learned man, who neglects me in a most insupportable manner; for I have it from persons of undoubted veracity, that he presumed once to pass by my door without waiting upon me. Whether this be consistent with the respect which we learned men ought to have for each other, I leave to your judgement, and am, Sir,

Your affectionate friend,

Philautus." 95

${ }^{80}$ Ibid. 565.

${ }^{90}$ The Guardian, Number 24.

91 Ibid. 107.

02 Ibid. 112.

Ibid. 156.

86 Ibid. 35.

${ }^{85}$ Ibid. 95. 
On the whole, the treatment of the new science in these papers is good-natured and kindly. The sharpest ridicule is directed against the foolish passion for dissection, for collecting rarities, and for studying the habits of insects. It is held that an absorbing interest in these despicable creatures of nature is an evidence of a "narrow genius", that such an interest dwarfs the mind instead of enlarging it, and that no results for the benefit of mankind can come from such a pursuit. "Studies of this nature should be the diversions, relaxation, and amusements, not the care, business, and concern of life". The pretenders to learning, both male and female, are exposed; where "terms are three-fourths of the business" there can be no sound learning. On the other hand, the possibilities in the new philosophy are perceived. The great discoveries are stimulating and inspiring; the minds of men are broadened by the work of Boyle, Huygenius, and Newton. To Addison, in particular, it was given to see the enlarged Horizon in the heavens above and the new world of minutiae on the earth beneath. The satire on the new science in The Tatler, The Spectator and The Guardian is as fair as satire can be made, which dilates upon the weaknesses and absurdities of a movement and passes over in silence the strong points. There is everywhere evidence of discrimination; commonsense and reason were sitting in the judgment-seat.

In the work of Daniel Defoe there is practically no new science. His type of mind no doubt naturally revolted from the "wary and circumspect" attitude of the investigators; he desired to be untrammelled by the bonds of truth. His world was the world of fiction where cleverness ruled and where there was no commandment, "Thou shalt not lie". The temperament of such a man would keep him from any appreciation of the Baconian philosophy. And it is found that he touches only incidentally upon certain phases, such as the method Dr. John Wallis proposed for "teaching the deaf and dumb to speak", ${ }^{96}$ the idea of "second sight" as defended by Joseph Glanvil, ${ }^{97}$ the medical practice of Dr. Radcliffe, ${ }^{98}$ and the belief in apparitions. ${ }^{99}$ The desire for novelty, of which it

${ }^{96}$ Cf. Duncan Campbell.

9 Duncan Campbell, chap. V.

98 Ibid. chap. VI.

${ }^{90}$ The Invisible World Disclosed, chap. V; The History of Magic. 
must be confessed some scientists were guilty, is satirized by him in his Miscellaneous Writings. ${ }^{100} \mathrm{He}$ has given, indeed, to the character of Robinson Crusoe the inventive genius of a virtuoso, but he was doubtless wholly unconscious of the connection with the new science. On the whole, his attitude is so obscure and his use of the new material is so slight that he may be convicted of indifference,-an indifference innate and temperamental.

The London Spy, after the manner of William King, makes a journey to London and reports in detail what he sees there. Inevitably he comes upon the virtuosi in his wanderings. To this Spy the scientist is "a Whimsie-headed Humorist", ${ }^{101}$ busied with a study of the weather-glass and the philosopher's stone. $\mathrm{He}$ spends his days in a laboratory filled with such "rarities" as a magnet, shells, flies, a unicorn's horn, an aviary of dead birds, serpents, together with other "Rusty-reliques and Philosophical Toys"'.102 The routine of his life has been reduced to a mechanical precision; he rises, dines, and sleeps by the tick of the clock. ${ }^{103}$ "He's a wonderful Antiquary, and has a closet of Curiosities outdoes Gresham Colledge". ${ }^{104}$ Nearly all of these curiosities have become familiar through previous satire. The list includes a "toothpicker of Epicurus", Diogenes's Lanthorn, the claws of an American Humming-bird, Heraclitus's tears frozen to a crystal, and a tenpenny nail out of the Ark. ${ }^{105}$ In the judgment of the Spy, the virtuoso is not distinguishable from those men who dwell in that "Madman's Colledge", Bedlam. "That man . . . . . that walks like a Mercury," he says of a lunatic, "as if he had wings to his Heels, is a Topping Virtuoso, and a Member of the Royal Society". ${ }^{108}$

There is nothing new in this representation of the new science. It may be seen at a glance that here again is the unjust, undiscrim-

${ }_{100} \mathrm{Cf}$. Life and Recently Discovered Writings, 1716-29, William Lee, vol. II, p. 43,44 , etc.

101 The London Spy, I, p. 12.

102 Ibid. II, p. 60.

103 Ibid. II, p. 13.

104 Ibid.

105 The London Spy, II, p. 13.

106 Ibid. III, p. 61. 
inating satire of comedy. Ward, in The London Spy, simply carries on the manner of attack of King, Brown, and the famous periodicals. He makes a clever use of new details, but the attitude is the same; it is an exploitation of the scientific humor.

In this manner was the new science attacked in prose. The source of material and the manner of treatment are practically the same as that of satirical comedy. These satirists were quick to eatch the flotsam and jetsam of scientific knowledge and cleverly transformed it into a ridiculous burlesque. The Philosophical Transactions and the scientific publications were the most common sources. Arbuthnot, a Fellow of the Royal Society, furnished facts and "jargon" for the Scriblerus Club. The absurd theories of Woodward, who was so generally unpopular, were made the butt of many an attack. Radcliffe, with his eccentricities, was likewise a good target for satiric shafts. From Brown to Ward the tone is little varied; written primarily to amuse the prose deals usually in a goodnatured manner with the new interest. The fiercest assaults are to be found in Gullivers' Travels and the Scriblerus Papers. In the latter, however, the humane feeling and essentially kindly spirit of Arbuthnot seem to have softened and tempered the fiercer moods of his friends. The boisterous burlesque in Brown's Dialogues, King's Journey to London, The Tatler, and The London Spy, is close akin to the representation in verse satire and comedy, but with something more of discrimination in it. "To make jests, to live and move in the ludicrous, to find fun in everything under heaven and over hell" was the business of these writers. If the jests become serious in Swift and the laughter unpleasant, they are counterbalanced by the conspicuous kindliness of Addison. The latter, indeed, gave to The Spectator a general attitude that was fair and generous, and once rose to an eloquent burst of enthusiasm inspired by the visions of the extended horizon of the new astronomy.

\section{III}

When -one turns to find a continued appreciation of the new philosophy or a reaction from the satiric attitude, in the first half of the eighteenth century, he meets with disappointment. "'uring the last quarter of the seventeenth century a spirited -ort 
was made to chronicle the new observations of science in the best literary form of the age, but it could not be sustained"' ${ }^{107}$ The splendid imagination of Burnet, awakened by the recent Cartesian speculations, had caught new visions of beauty, to which he gave expression in passages of literary eloquence. His Sacred Theory became the centre of a theological storm whose mutterings did not entirely die away for forty years. ${ }^{108}$ From him leads a most alluring trail into the land of speculative theology where dwell Bentley, Clarke, Butler, and Mandeville. These men were "occupied with an intense and eager curiosity by speculation on the first principles of natural religion", ${ }^{109}$ striving to harmonize the "painful discord" between reason and revelation. "The scientific frontier between reason and revelation is in the hottest of the melee, and the deists, extending the claims of reason, say or insinuate that the results tell against the Church articles. The apologists like Clarke and Bentley try to prove the being of God either a priori, or from the world as understood by the new science". ${ }^{110}$ However alluring this path, it is certainly a digression from the plan of study of this work. And there is a second way from the sacred Theory, taken by the virtuosi themselves, which leads through Ray's Wisdom of God, Whiston's New Theory, and the polemical work of Keil. The first two have have been treated, and the last has no claim to literary merit. It may be seen, therefore, that in the early years of the eighteenth century there were bounds set to certain fields of speculation; (1) Locke had clearly discriminated between the subject-matter of human philosophy and the problems of natural philosophy, (2) the new science, breaking the yoke of ecclesiastical authority, had asserted "the freedom of the scientific intellect", (3) the problems of sociology, political economy, and history, were distinguished from the investigations of natural science. Each field of intellectual endeavor, thus specialized, yielded its own harvest of books.

Natural science was continued through these years with indefatigable energy, but no great new discoveries were made. There-

107 Gosse, Edmund, History of 18th Century Literature, p. 375.

108 Supra, chap. II.

Elton, Oliver, The Augustan Ages, p. 269.

110 Ibid. p. 270. 
fore, while the new ideas of the late seventeenth century were furnishing inspiration and imagery to certain pious poets, the new philosophy in prose filled "a class of books which cannot be called literature". Its direct expression is to be found in such books as Desaguliers's $A$ Course of Experimental Philosophy, Stephen Gray's Experiments in Electricity, and the volumes of the Philosophical Transactions. But in these books "the graces were tacitly and gradually excluded from all treatment of purely utilitarian problems and exact observations, and this exclusion divided the vast body of what was written into literature and non-literature". ${ }^{111}$

The human philosophers, with the exception of Shaftesbury, however much they may have been subtly influenced by the scientific method and discovery, established their attitude by casual reference. "I deny not", says Locke in his Essay on Human Understanding, "but, a man, accustomed to rational and regular experiments, shall be able to see farther into the nature of bodies, and guess righter at their yet unknown properties, than one thai is a stranger to them; but yet, as I have said, this is but judgment and opinion, not knowledge and certainty. The way of getting and improving our knowledge in substances only by experience:s and history, which is all that the weakness of our faculties in this state of mediocrity we are in in this world can attain to, makes me suspect that natural philosophy is not capable of being made a science". ${ }^{112}$ And then he adds, in the manner of an apology,"I would not therefore, be thought to disesteem or dissuade the study of nature." 113 To the Idealist, Berkeley, the search for natural causes is misdirected effort. "It is the searching after and endeavoring to understand this Language (if I may so call it) of the Author of Nature, that ought to be the employment of the natural philosopher; and not the pretending to explain things by corporeal Causes, which doctrine seerns to have too much estranged the minds of men from the Active Principle, that Supreme and Wise Spirit 'in whom we live, move, and have our being' '. ${ }^{114}$

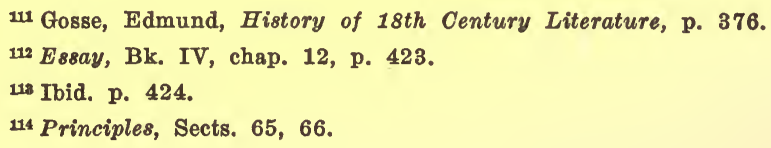


In the Characteristics of Shaftesbury, however, there is an interesting idealization of the virtuoso. "Every man", he asserts, "is a virtuoso, of a higher or lower degree". ${ }^{115} \mathrm{He}$ then proceeds to point out that the danger in this interest lies in "falling in love with rarity for rareness' sake". The men who do this, he admits, are deserving of the ridicule which they receive $;^{116}$ but there is a study worth the pursuing. "I am persuaded that to be a Virtuoso (so far as befits a Gentleman) is a higher step toward becoming a Man of Virtue and good sense, than the being what in this Age we call a Scholar". ${ }^{117}$ There is, furthermore, no ground for prejudice against the new philosophy, for it does not contain anything to bias a man's mind in the study of other problems. ${ }^{118}$ After this defense there comes a passage in which the broadened horizon has stimulated the imagination of this philosopher; the "diocentric idea", which John Locke received from the new astronomy, has dawned upon him also. "Yet is this Mansion-Globe, this Man-Container, of a much narrower compass even than its other fellow Wanderers of our system. How narrow then must it appear, compar'd with the spacious system of its own Sun? And how narrow, or as nothing, in respect of those innumerable systems of other apparent suns?" "118 The Newtonian discoveries concerning light also inspired him to write that rather eloquent passage beginning,-_"But wither shall we trace the sources of light? or in what Ocean comprehend the luminous matter so wide diffus'd thro' the immense spaces which it fills?" "119

There was in this philosopher a sensible and a genuine appreciation of the new science. He saw clearly the abuses of pretenders to learning and felt that the satire on them was fully merited; but he saw also its nobler aspects and himself caught some of the zeal of discovery. His mind was drawn into speculative philosophy rather than experimental science, and yet this "Virtuoso of Humanity" was broad-minded enough to commend the excellent service the experimenters were performing.

115 Characteristics, vol. I, p. 138.

116 Ibid. II, 253.

117 Characteristics, I, p. 290.

118 Ibid. A Rhapsody, II, p. 373.

110 Ibid. p. 379. 
There is no further representation of the new science in the prose literature of the period. A few echoes of the deistic controversy were still faintly reverberating, in which spiteful allusions were made indirectly to the new scientific knowledge of nature. But Joseph Butler's Analogy (1736) had taken all the point out of, if it had not really ended, that dispute which was ever only remotely connected with the new science. ${ }^{120}$ A single illustration will serve to show the type of criticism and will indicate also the general attitude of indifference toward scientific investigations. "The zeal for this sort of Gibberish (science)", wrote Julius Bates sarcastically (1774), "is greatly abated of late, and tho' it is now upwards of twenty years that the Dagon of Modern Philosophers, Sir Isaac Newton, has lain with his face upon the ground before the Ark of God, Scripture Philosophy . . . . . yet there is not one of the whole society who hath the courage to attempt to raise him up. And so let him lye". ${ }^{121}$

It is a striking literary phenomenon that the scientific discoveries produced no great masterpiece. Several reasons for this fact readily suggest themselves; the zest of discovery had doubtless somewhat abated in the early years of the eighteenth century, certainly experiments had lost much of their novelty, and literary prose was more and more occupied with other things, such as satiric and journalistic essays, human philosophy, theology, and the novel. ${ }^{122}$ Perhaps the most potent reason of all is the fact that no great new discoveries came to reward the scientific labors. Natural science came gradually to be accepted as a legitimate field for intellectual activity and ceased to call attention to itself. That satiric exploitation of it was passing away is a good indication of its rise into a position of dignity and honor. Dr. Johnson accepts the new science as a matter of course and evinces some surprise at the earlier attitude. "Some verse in the last collection, shew him (Butler) to have been among those who ridiculed the institution of the Royal Society, of which the enemies were for some time very numerous and very acrimonious; for what reason is hard to conceive, since the philosophers professed not to advance doctrines but

$120 \mathrm{Cf}$. The Boyle Lectures of Bentley and Clarke.

121 Bates, Julius, The Philosophical Principles of Moses Asserted, p. 2.

122 Gosse, Edmund, History of 18 th Century Literature, p. 378. 
to produce facts; and the most zealous. enemy of innovation must admit the gradual progress of experience, however he may oppose hypothetical temerity". ${ }^{123}$

In the death of Newton the new science sustained an irreparable loss. When the stimulation of his work and the inspiration of his personality were gone, there succeeded a period barren of discoveries. Desaguliers might popularize the new ideas, but he could not produce new discoveries ; antiquarianism became a gentleman's diversion and relaxation; Hauksbee and Stephen Gray were only preparing the way for Franklin's brilliant work. The scientists were standing between two periods, one of a past great achievement and the other yet to dawn.

123 Johnson's Lives, I, p. 208, Butler. Cf. also his attitude as expressed in his Life of Boerhave. 


\section{CHAPTER VI}

\section{ConCLusion}

The assigned task is now finished. The new science has been characterized, its activities have been traced briefly along the various lines of interest, and its contributions of new ideas to English thought have been summarized. The struggle of these new ideas with the "ancient faith", with an outworn poetic imagery, with the claims of pseudo-science, with the power of scholastic authority, and with the credulity of superstition, has been presented, in so far as it found literary expression. An exploitation of this new interest as a humor that filled the minds of men and women with foolish whimsies was discovered in the satiric comedies. In verse, the new philosophy fell into the grasp of the satirists, whose treatment much resembled that of comedy; but, later, certain poets were led through a sense of piety to find the extended horizon of the new astronomy, while others began to look upon external nature, like the virtuosi, with the wondering eyes of children. In prose, there was an early and enthusiastic literary expression of the new discoveries by the scientists themselves, that soon lost its vigor. Satire took its place, that, like comedy, exaggerated the absurdities of the new interest. Gradually the inquiries of natural science were differentiated from speculative philosophy and theology; science developed a literature of its own wherein "the graces were tacitly excluded". "An age of scientific discovery till then unexampled passed away without enriching literature by a single classic", ${ }^{1}$ but natural science made for itself a place of dignity and respect among the other branches of human thought.

The new science was found to be a new intellectual impulse that set men at work reconstructing the natural history of the world by means of experiment and observation. Attention was thereby called to the objective forms of nature and interest was centered upon the affairs of secular life. The day of specialization was dawning; the new philosophers, who began, like Bacon, with the whole province of human knowledge, steadily narrowed their

1 Garnett, Richard, The Age of Dryden, p. 266. 
field of investigation to the connotation of the modern term, natural science. Even this circumscribed interest was broken up into specialized studies, such as botany, chemistry, mathematies, physics, physiology, etc. Investigations were carried on by the active members of the Royal Society with great energy, and a reward of their efforts in startling and revolutionizing discoveries came quickly and abundantly through the last quarter of the seventeenth century, giving place in the eighteenth to a continued, but scantily repaid, experimental activity which prepared the way for the work of Franklin in Electricity, Priestley in Chemistry, and Alexander Smith in Geology. A world of minutiae was revealed by the microscope, and through the telescope came ocular proof of the Copernican theory. Man became "an insignificant atom of an atom-world". Mathematics demonstrated the law of gravitation; Physics gave a new interest to the atmosphere, to light, color, heat; Botany made men to see with an awakened curiosity the flowers and the beasts of the field; Physiology discovered the wonderful framework of the human body; a study of "rarities" led to antiquarian research, to which were related an interest in history and an investigation of geographical and geological problems. Thus were these new scientists entering "the wonderland of modern science".

'As the light of these new discoveries came flooding in, the old hypotheses did not fall without noise.' It was a transitional period. The point of view of men was sometimes radically changed, as in the case of Sir Thomas Browne; new poetic imagery struggled with the out-worn and conventional for expression in Cowley, Denham, Waller, and others; Milton stood in doubt before the new ideas and finally evaded the whole issue; Dryden, engrossed with the affairs of men, shifting his allegiance like changes of raiment, was practically unaffected by the new intellectual impulse. Thomas Sprat first lifted his voice in defense of the Royal Society against the opposition of churchmen and "Wits and Railleurs", which lasted through the period. "The 'shock of that collision is far from having spent its effect even in our own day"'.2 Sharp conflicts centered in the work of Glanvil, in Burnet's Sacred Theory, and in Swift's Tale of the Tub, Battle of the Books, and Partridge

${ }^{2}$ Courthope, W. J., History of English Poetry, vol. III, p. 168. 
Papers. The new philosophy made headway, however, against all opposition, and one by one "cast down the old idols of prejudice, superstition, and ancient authority; it gave a few new images to the transition poets, and to Milton and Burnet a new conception of the illimitable expanse of the universe.

Satiric comedy exploited the new interest as a humor, after the manner of Ben Jonson. First touched upon in Shackerley Marmion's The Antiquary (1641), it was developed by Shadwell into that arch-type of the virtuoso, Sir Nicholas Gimerack (The Virtuoso, 1667). The exploitation continued through Durfey, Aphra Behn, Mrs. Centlivre, Colley Cibber, and others, ending so far as this study is concerned with the anonymous State of Physick (1642). Wherever the new scientist appears in comedy, with a single exception (Dr. Easy, The State of Physick), he receives the merited contempt of all men, because he is a pedantic "fool", engaged in the pursuit of useless knowledge. "I believe," said Snarl, the cynic, "if the Blood of an Ass were transfus'd into a virtuoso, you would not be able to know the Emittent Ass from the Recipient Philosopher, by the Mass". ${ }^{3}$ This is the consensus of satiric opinion. The virtuoso was never generally distinguished from the quack doctor and the astrologer; remnants of the oceult sciences still clung to him, such as alchemy, the Rosicrucian mysteries, and astrology. The severest censure was based upon the scientist's waste of money in buying scientific apparatus and "rarities", and in pursuing studies that could never benefit himself or anyone else,-in "studying not his country's good but her insects". That this satire was generally unmerited and unjust has been made sufficiently clear. Doubtless there were pedants in plenty, as there ever are, but neither the great men nor their great achievements were appreciated by the writers of comedy. The virtuoso never invented anything so useful as a mouse-trap, said the satirists; yet the air-pump, the thermometer, the microscope, the improved telescope, the barometer, and the steam-engine came out of this period. A bricklayer is worth forty philosophers, averred the satirists; yet Hooke, Boyle, Ray, Willughby, Grew, Mayow, Lower, Sydenham, Sloane, Newton, to say nothing of the foreigners closely associated with the new interest, as Leeuwenhoek, Malpighi,

shadwell's The Virtuoso, Act II. 
Boerhave, lived at this time. The inevitable injustice of satire is here,-the exaggeration of weaknesses, the omission of virtues.

The satiric poets, from the sullen and morose Butler to the "Wasp of Twickenham", took their fling at the new philosophy. In their verse there is the same exploitation, the same lack of discrimination, the same desire "to make their readers sport whether the persons exposed deserve it or not", as in comedy. In Butler there is bitterness; in Pope there is a temperamental "painful discord"; in the rest there is rude and boisterous laughter. But piety led Prior, Blackmore, Savage, Brooke, and Young into an appreciation of the new astronomy; the loftiest verse outside of Milton's was directly inspired by the "new heaven of the telescope". To the Thomsonian poets, influenced by the new interest of science, it was given to eatch a glimpse of a new world in external nature. "They walked in nature as in a garden, and tasted of its plenty". In them was begun that process of harmonizing imagination and the scientific spirit for which Wordsworth preached, when "Science should become the handmaid of Literature". The infinite variety of "imaginations and similitudes", which the too optimistic Sprat had prophesied, did not come to them, but they did gain in imagery, in inspiration, and, perhaps more than can be calculated, in attitude and spirit; for "there first awoke in them the general idea of the importance of an objective attitude to nature and of the new use of systematic experiment". 4

In the prose treatment of the new science there are three fairly distinct phases; first, an early appreciation during the last forty years of the seventeenth century, secondly, a satiric exploitation extending from Eachard to the London Spy, thirdly, an incidental representation in the human philosophers and a direct, non-literary exposition from the virtuosi themselves. Flushed with the zeal of discovery, the new philosophers "made a spirited effort to chronicle the new observations in the best literary form of the age". The attempt fell gradually away at the beginning of the eighteenth century, but meanwhile there was developed a prose ideal, a "clear, naked style, approaching mathematical plainness", whose "virtues spread and wrought with the instinct of conversation and social amenity, and with the love of argument and pleading and oratory,

4 Cambridge History of English Literature, vol. IV, p. 328. 
to form modern style". ${ }^{5}$ There is a contagious enthusiasm in much that they wrote, from the earlier men like Wilkins, through Evelyn, Boyle, Hooke, and Newton. But there was no literary genius among the virtuosi directly inspired of the new science; their work had a permanent effect on English thought, but not on English literature. Even Newton, with his "brooding mind, took no thought for literary expression". Then, once again, the new science was "exposed" by satire, in those exceedingly clever attacks in prose. Eachard, the schoolmaster, King, Brown, Swift, the Scriblerus Club, conjointly, Arbuthnot, The Tatler, The Spectator, The Guardian, Defoe, and The London Spy, all launched satiric darts at the new philosophy. It was another exploitation of a humor, with more discrimination, to be sure, than comedy and verse possessed. The tone throughout is little varied; the raillery is good-natured, except in Swift; the fairness and candid good-sense of The Tatler and The Spectator are remarkable. In the last mentioned periodicals the absurdities of the new interest are fairly characterized, and the great men and their splendid achievements find some appreciation. Addison, in particular, had caught the vision of "the heavens of the new astronomy". There is no re-action in this period to counterbalance the satire. Locke and Berkeley only touch upon the new science in the midst of a hundred other interests; the deistic controversy, which found its culmination in Butler's Analogy, drew from the new experiments the new conception of the physical universe; Shaftesbury, alone, among the human philosophers and theologians, gave an appreciative expression to the new philosophy in his idealization of the virtuoso. Further than this, the new science received a direct exposition in a non-literary style of its own, and separating itself from history, theology, human philosophy, and classical learning, took its honorable place among the other branches of human thought.

Here the investigation stops, though the literary phenomenon is not complete. With the passing away of Pope, however, there ended a satiric, inappreciative attitude; at that time, too, natural science ceased to be on the defensive, and the movement toward the literary use of the results of experiments and observations had begun. The new intellectual impulse had entered the minds of

Elton, Oliver, The Augustan Ages, p. 420. 
men with its transforming and quickening power, and was developing its subtle relationship with realism. Poets had begun to learn that "observation and experience are the ballast needed to give imagination steadiness". ${ }^{8}$ The effects of the scientific ideas were longer in making themselves felt than those of the classical renaissance, because "national characteristics are never so strongly marked in science and philosophy as in other branches of literature".7 The "painful discord" was not yet wholly harmonized; as, indeed, it can never be. There is always a discord that is temperamental and irradicable. Lowell said, with Yankee shrewdness and wit, that "the more she (Science) makes one lobe of our brain Aristotelian, so much the more will the other intrigue for an invitation to the banquet of Plato".8 Edgar Allan Poe is an illustration of the point, in whom imagination, desiring to be free, picks a half-whimsical quarrel with the demand of science for matters of fact.-

"Science! true daughter of old Time thou art!

Who alterest all things with thy peering eyes.

Why preyest thou upon the poet's heart,

Vulture, whose wings are dull realities?

How should he love thee? or how deem thee wise?

To seek for treasure in the jewelled skies,

Albeit he soared with an undaunted wing?

Hast thou not dragged Diana from her car?

And driven the Hamadryad from the wood

To seek shelter in some happier star?

Hast thou not torn the naiad from her flood,

The Elfin from the green grass, and from me,

The summer dream beneath the tamarind tree?",

Audience may be given to voices of three men of literary genius from the nineteenth century, on the relationship between literature and science. In his Preface to the Lyrical Ballads, 1815, Wordsworth wrote:- "The knowledge both of the Poet and the Man of science is pleasure; but the knowledge of the one cleaves to

' Neilson, W. A. The Essentials of Poetry, p. 137.

7 Cambridge History of English Literature, vol. IV, p. 308.

${ }^{8}$ Latest Literary Essays, p. 183.

- Sonnet, To Science. 
us as a necessary part of our existence, our natural and inalienable inheritance; the other is a personal and individual acquisition, slow to come to us, and by no habitual and direct sympathy connecting us with our fellow-beings. The Man of Science seeks truth as a remote and unknown benefactor, he cherishes it and loves it in solitude; the Poet, singing a song in which all human beings join with him, rejoices in the presence of truth as our visible friend and hourly companion. Poetry is the breath and finer spirit of all knowledge; it is the impassioned expression which is in the countenance of all science . . . . . Poetry is the first and last of all knowledge-it is as immortal as the heart of man. If the labours of the Men of Science should ever create any material revolution, direct or indirect, in our condition, and the impressions which we habitually receive, the Poet will sleep then no more than at present; he will be ready to follow the steps of the Man of Science, not only in those general indirect effects, but he will be at his side, carrying sensation into the midst of the objects of the science itself. The remotest discoveries of the Chemist, the Botanist, or the Mineralogist, will be as proper objects of the Poet's art as any upon which it can be employed, if the time should ever come when these things shall be familiar to us, and the relations under which they are contemplated by the followers of these respective sciences shall be manifestly and palpably material to us as enjoying and suffering beings. If the time should ever come when what is now called science, thus familiarized to men, shall be ready to put on, as it were, a form of flesh and blood, the Poet will lend his divine spirit to aid the transfiguration and will welcome the Being thus produced, as a dear and genuine inmate of the household of man." ${ }_{10}$

Tennyson, writing out of a period strikingly similar in some respects to the Restoration in that new scientific discoveries were revolutionizing human thought, asked of himself and of all poets, -

"Is this.

A time to sicken and swoon,

When Science reaches forth her arms

To feel from world to world, and charms

Her secret from the latest moon?"11

${ }^{10}$ Wordsworth, Preface to Lyrical Ballads, 1815; cf. also The Prelude.

i1 Tennyson, In Memoriam. 
And, finally, in the second half of the nineteenth century, when natural science had come more fully into.her own and "humane letters" were on the defensive, Matthew Arnold said in reply to Huxley,-_"But how, finally, are poetry and eloquence to exercise the power of relating the modern results of natural science to man's instinct for conduct, his instinct for beauty? And here again I answer that I do not know how they will exercise it, but that they can and will exercise it, I am sure." 12

It seems reasonable to believe that human thought will continue to progress by this same process of discovery, opposition, and reconciliation. If the literary mind cherishes the old idols, clings to the ancient faith after they are disowned by the philosophers, it will certainly at last "lend its divine spirit to aid in the transfiguration and will welcome the new truths into the household of man".

12 Discourses in America, Lit. and Science. 


\section{BIBLIOGRAPHY}

Addison, Joseph, Works, 4 vols. Ed. Bohn, London, 1890.

Akenside, Mark, Poems, British Poets, vols. LII, LIII, Chiswick, 1882; Chalmers's English Poets, vol. XIV.

Arber, Edward, Reprints, 14 vols.

Arbuthnot, John, Works, 2 vols, 2nd. ed. Glasgow, 1751.

Armstrong, John, Poems, Chalmers's English Poets, vol. XVI.

Bacon, Sir Francis, Works, Ed. James Spedding and R. L. Ellis, 7 vols. London, 1857-9.

Barkers, (Mrs.) Jane, Poetical Recreations, London, 1688.

Bates, Julius, The Philosophical Principles of Moses Vindicated, London, 1744.

Bates, Katherine Lee, English Drama, A Working Basis, Boston, 1896.

Beattie, James, Poems, Chalmers's English Poets, vol. XVIII.

Becker, B. H., Scientific London, New York, 1875.

Behn, (Mrs.) Aphra, Dramatic Works, London, 1874.

Beljame, Alex., Le Public et les hommes de lettres en Angleterre au dixhuitieme siecle, Paris, 1883.

Bentley, Richard, Works, Ed. Dyce, 3 vols. 1836-8.

Berkeley, George, Works, 3 vols. Ed. Sampson, London, 1898.

Besant, Sir Walter, London in the Eighteenth Century, London, 1903; London in the Time of the Stuarts, London, 1903.

Biographia Dramatica, Isaac Reed and Stephen Jones, 3 vols. London, 1812.

Birch, Thomas, History of the Royal Society, 4 vols. London, 1756-7.

Blair, Robert, Poems, Chalmers's English Poets, vol. XV.

Bolingbroke, Viscount, (St. John), Philosophical Works, Ed. Mallet, 5 vols. London, 1754.

Boyle, Hon. Robert, Ed. Birch, 5 vols. London, 1744.

Broome, William, Poems, Chalmers's English Poets, vol. XII.

Brown, Thomas, A Collection of all the Dialogues, London, 1704.

A Legacy for the Ladies; or, Characters of the Women of the Age, London, 1705.

Works, Serious and Comical, Prose and Verse, 4 vols. London, 1715.

Browne, Sir Thomas, Works, 3 vols. Ed. Simon Wilkin, London, 1852.

Buckingham, Duke of, (George Villiers), The Rehearsal, Ed. Arber, London, 1868.

Buckinghamshire, Duke of, (John Sheffield), Poems, Chalmers's English Poøts, vol. $\mathrm{X}$.

Buckle, T. H., History of Civilization in England, London, 1892.

Bulstrode, Richard, Memoirs and Reflections, London, 1721.

Burnet, Gilbert, History of His Own Times, London, 1753.

Burnet, Thomas, The Sacred Theory of the Earth, 2 vols. London, 1687.

Butler, Joseph, Works, 2 vols. Oxford, 1835-6.

Butler, Samuel, Poetical Works, 2 vols. Aldine Poets.

Byrom, John, Poems, Chalmers's English Poets, vol. XV. 
Cambridge History of English Literature, The, vols. III, IV, VII, VIII, IX.

Candolle, Alphonse, L'Histoire des Sciences, Geneva, 1873.

Centlivre, (Mrs.) Sarah, Dramatic Works, 3 vols. London, 1761.

Chalmers, A., English Poets, 21 vols. London, 1810.

Charlanne, Louis, L'Influence Francaise en Angleterre, au XVII" Siecle, Paris, 1906.

Chesterfield, Earl of, Letters, Oxford, 1890.

Cibber, Colley, Dramatic Works, 5 vols. London, 1736.

Clarke, Samuel, Works, 4 vols. London, 1738.

Collier, J. P., History of English Dramatic Poetry and Annals of the Stage,

3 vols. London, 1879.

Congreve, William, Dramatic Works, London, 1887.

Courthope, W. J., History of English Poetry, 5 vols. London, 1895-1910.

Cowley, Abram, Works, Ed. Grosart (Chertsey Worthies) London, 1881.

Crown, John, Dramatic Works, 4 vols. Edinburgh, 1873-4.

Davenant, Sir William, Works, 5 vols. Edinburgh, 1882-4.

Defoe, Daniel, Works, 20 vols. Oxford, 1840-1.

Denham, John, Poems and Translations, with the Sophy, London, 1668.

Dennis, John, The Age of Pope, (1700-1744), London, 1901.

Descartes, Rèné, Philosophical Works, The Method, Meditations, and Philosophy of Descartes, Translated by John Veitch, Washington, 1901.

Dorset, Charles, Earl of, Chalmers's English Poets, vol. VIII.

Dryden, John, Works, Ed. Scott and Saintsbury, 13 vols. 1882-8.

Durfey, Thomas, Plays, Madam Fickle; or, the Witty False One, London, 1732.

Dyer, John, Chalmers's English Poets, vol. XVII.

Eachard, John, Observations on the Enquiry into the Grounds and Occasion of the Contempt of the Clergy, 1671, cf. Arber's Reprints.

Earle, John, Micro-Cosmographie, 1628, Ed. Arber.

Elton, Oliver, The Augustan Ages, New York, 1899.

Encyclopedia Britannica, 11th Ed. Astronomy, Chemistry, Zoology.

Etheredge, Sir George, Ed. Verity, London, 1888.

Evelyn, John, Diary, Ed. Wheatley, 4 vols. London, 1879.

Silva; or, $A$ Discourse of Forest Trees, York, 1776.

Sculptura, Ed. C. F. Bell, Oxford, 1906.

Acetaria, London, 1699.

Farquhar, George, Works, II vols. 5th ed. London, 1721.

Fielding, Henry, Works, Ed. Leslie Stephens, 10 vols. 1882-3.

Foster, Sir M., Lectures on the History of Physiology during the Sixteenth, Seventeenth and Eighteenth Centuries, Cambridge, 1901.

Frauenstadt, Christian M. J., Die Naturwissenschaft in ihren Einfluss auf Poesie, Religion, Moral und Philosophie, Leipsig, 1855.

Garnett, Richard, The Age of Dryden, London, 1901.

Garth, Samuel, The Dispensary, London, 1689.

Poems, Chalmers's English Poets, vol. IX; British Poets, vol. XXVII.

Gay, John, Works, 6 vols. London, 1772-8.

Genest, G., Some Account of the English Stage, Bath, 1832. 
Gildon, Charles, Miscellaneous Letters and Essays, on Several Subjects, London, 1694.

Glanvil, Joseph, Sadducismus Triumphatus, London, 1726.

Scepsis Scientifica, London, 1885.

Essays on Several important subjects in philosophy and religion.

Glover, Richard, Poems, Chalmers's English Poets, vol. XVII.

Gosse, Edmund, A History of Eighteenth Century Literature, 1660-1780, New York-London, 1891.

Green, Matthew, Chalmers's English Poets, vol. XVं.

Greenslet, Joseph, Joseph Glanvil, New York, 1901.

Guardian, The, cf. Wks. of Addison.

Halifax, Earl of, Chalmers's English Poets, vol. IX; Anderson's Poets, vol. VI; Sharpe's Poets, vol. 89.

Hallam, Henry, Introduction to the Literature of Europe, 4 vols. London, 1882. Halliwell-Phillips, J. O., A Dictionary of Old English Plays, London, 1860.

Hettner, Hermann, Geschichte der englischen Literatur von der Wiederherstellung des Königthums bis in die zweite Hälfte des achtzehnten Jahrhunderts, 1660-1770, Braunschweig, 1894.

Hooke, Robert, Micrographia, London, 1665.

Howard, Sir Robert, Works, London, 1722.

Hughes, John, Poems, Chalmers's English Poets, vol. X; Anderson's Poets, vol. VII; Sharpe's Poets, vol. 89.

Hunt, J., Religious Thought in England, 2 vols. London, 1870-2.

Johnson, Samuel, Works, Ed. Murphy, 12 vols. London, 1824.

Jonson, Ben, The Alchemist, Ed. C. M. Hathaway, 1904.

Jusserand, J. J., A Literary History of the English People, New YorkLondon, 1909.

King, William, Miscellanies in Prose and Verse, London, (no date).

La Croix, Paul, Dix-Huitieme Siecle, letters, sciences et arts, France, 17001789, Paris, 1878.

La Croix, Paul, Science and Literature in the Middle Ages, London, 1878.

Lacy, John, Dramatic Works in the Restoration Dramatists, vol. I, London, 1875 .

Langbaine, G., An Account of English Dramatic Poets, London, 1691.

Lecky, W. E. H., England in the Eighteenth Century, 8 vols., New York, 1888-91.

Lloyd, Robert, Chalmers's English Poets, vol. XV.

Locke, John, Philosophical Works, Ed. St. John, London, 1879.

Lodge, Oliver J., Pionerrs of Science, New York, 1893.

Longueville, Thomas, Rochester and other Literary Rakes of the Court of Charles II, with some Account of their Surroundings, Boston, 1903.

Masterman, J. H. B., The Age of Milton, London, 1901.

Milton, John, Works, Ed. J. Toland, Amsterdam, 1698; Ed. J. Mitford, London, 1863.

Montagu, Lady Mary Wortley, Works, 5 vols. London, 1803.

Macaulay, T. B., History of England, 5 vols. New York, 1849. 
Marmion, Shackerley, Plays in the Restoration Dramatists, vol. I.

Marvell, Andrew, Works, 4 vols. Ed. Grosart, 1872-5.

Masson, David, Life of Milton in Connexion with his Times, 6 vols. London, 1881 and 1894.

Millar, J. H., The Mid-Eighteenth Century, New York, 1902.

Miller, James, The Humours of Oxford, London, 1726.

Neilson, W. A., The Essentials of Poetry, Boston, 1911.

Newcastle, Duchess of, The Philosophical and Physical Opinions of, London, 1655.

Poems, Dyce, Alex., Specimens of British Poetesses, London, 1827.

Newton, Sir Isaac, Works, London, Memoirs of the Life, Writings, and Discoveries, Sir D. Brewster, 1855.

Nichols, John, Biographical and Literary Anecdotes of the Eighteenth Century, 2 vols. London, 1782.

Oldham, John, Works, 2 vols. London, 1722.

Compositions in Prose and Verse, 3 vols. London, 1770.

Poems of State Affairs.

Otway, Thomas, Works, 3 vols. 1813.

Parnell, Thomas, Poetical Works, London, 1890.

Chalmers's English Poets, vol. IX.

Partridge Papers, The, cf. Works of Swift and Steele.

Pattison, Mark, Milton, New York, 1880.

Pearson, Norman, Society Sketches in the XVIIIth Century, London, 1911.

Pepys, Samuel, Diary, 6 vols. London, 1876-9.

Perry, T. S., English Literature in the Eighteenth Century, New York, 1883.

Philips, Ambrose, Poems, Chalmers's English Poets, vol. XIII.

Philips, John, Poems, Chalmers's English Poets, vol. XIII.

Phillips, J. O., (Halliwell), Science in England from Elizabeth to Charles II.

Philosophical Transactions, 207 vols. 1665-1744.

Pope, Alexander, Ed. Warburton, 9 vols. London, 1757, Ed. Elwin and Courtthope, 10 vols. $1870-89$.

Prior, Matthew, Poetical Works, cf. The Aldine Poets, Chalmers's English Poets, vol. X.

Pultney, R., The Progress of Botany in England, 2 vols.

Ranke, Leopold (von), History of England, 6 vols. 1875.

Remusat, Charles de, Histoire de la Philosophie en Angleterre, 2 Tomes, Paris, 1878.

Rochester, John Wilmot, Earl of, Poems, Chalmers's English Poets, vol. VII, Poems of State Affairs; History of Insipids, London, 1709.

Roscommon, Earl of, Poems, Chalmers's English Poets, vol. VIII.

Minor Poets, 3 vols.

British Poets, vol. XX.

Sachs, Julius (von), History of Botany, Oxford, 1890.

Savage, Richard, Poetical Works, Ed. Johnson, 2 vols. 1771.

Scriblerus Papers, The, cf. Works of Arbuthnot, Pope and Swift.

Sedley, Sir Charles, Works, 2 vols. London, 1778. 
Seth, James, English Philosophers, and Schools of Philosophy, Edinburgh, 1912. Settle, Elkanah, Brown, Frank C. Chicago, 1910.

Shadwell, Thomas, Dramatic Works, 4 vols. 1720.

Shaftesbury, A. A. C., Earl of, Characteristics, 2 vols. New York, 1900.

Shenstone, William, Poetical Works, Edinburgh, 1868.

Poems, Chalmers's English Poets, vol. XIII.

Somerville, William, Poems, Chalmers's English Poets, vol. XI.

Southerne, Thomas, Dramatic Works, 2 vols. London, 1713.

Spectator, The, 6 vols. Ed. G. G. Smith, London, 1897.

One volume, Ed. Morley, London, 1891.

Sprat, Thomas, History of the Royal Society, London, 1667.

Poems, Minor Poets.

State of Physick, The, A Comedy, Anon. Printed in Plays Not Acted, (Genest).

Steele, Sir Richard, Works, Ed. Dobson, London, 1885.

Stephens, Leslie, History of English Thought in the Eighteenth Century, 2 vols., 2nd ed. London, 1881.

Swift, Jonathan, Works, Ed. Sir W. Scott, 19 vols. London, 1883-4.

Sydney, W. C., England and the English in the Eighteenth Century, 2 vols. Social Life in England, 1660-1690.

Taine, H. A., History of English Literature, Transl. by H. Van Locen, 2 vols. in one, New York, 1886.

Tatler, The, British Essayists, vols. 1-5.

Temple, Sir William, Works, 4 vols. London, 1770.

Thomson, James, Poetical Works, The Aldine Poets.

Thompson, Thomas, History of the Royal Society, London, 1812.

History of Chemistry, London, 1830-1.

'Tickell, Thomas, Chalmers's English Poets, vol. XI ; British Poets, vol. XXVII.

Towgood, William, Zootomia; or, A Morrall Anatomy of the Living by the Dead, London, 1653.

Traill, H. D., Social England, 6 vols. London, 1894-1905.

Tulloch, John, Rational Theology and Christian Philosophy, 2 vols. LondonEdinburgh, 1874.

Vanbrugh, Sir John, Dramatic Works, 2 vols. London, 1893.

Waller, Edmund, Works in Prose and Verse, London, 1744.

Walton, Izaak, and Cotton, Charles, The Complete Angler, London, 1903.

Ward, A. W., History of English Dramatic Literature to the Death of Queen Anne, London, 1899.

Ward, Edward, The London Spy, London, 1709.

Weld, C. R., History of the Royal Society, 2 vols. London, 1848.

Wendell, Barrett, The Temper of the Seventeenth Century Literature, New York, 1904.

West, Richard, Anderson's British Poets, vol. X; Sharpe's Poets, vol. 93.

Wheatley, H. B., Samuel Pepys and the World he Lived in, London, 1895.

Whitehead, William, Poems, Chalmers's English Poets, vol. XVII.

Wilkins, John, Discovery of a New World in the Moon, London, 1638.

Wilson, John, The Cheats, in The Restoration Dramatists, vol. I. 
Winchelsea, Anne, Countess of, Poetical Works, Ed. Myra Reynolds, Chicago, 1904.

Wood, Anthony a., Athenae Oxoniensis, Ed. Bliss, London, 1815.

Wordsworth, Christopher, Scholae Academicae, London, 1877. Social Life at the English Universities in the Eighteenth Century, London, 1874.

Wotton, William, Reflections upon Ancient and Modern Learning, London, 1694.

Wright, Thomas, The Female Virtuosoes, London, 1693-7.

Wycherley, William, Dramatic Works, London, 1887.

Yalden, Thomas, Poems, Chalmers's English Poets, vol. XI.

Young, Edward, Poems, 3 vols. London, 1802. 

(27)

709 

PLEASE DO NOT REMOVE CARDS OR SLIPS FROM THIS POCKET

UNIVERSITY OF TORONTO LIBRARY 
